\title{
The Thrust Belt in \\ Southwest Montana and East-Central Idaho
}

By EDWARD T. RUPPEL and DAVID A. LOPEZ

GEOLOGIGAL SURVEY PROFESSIONAL PAPER 1278

An interpretation of the leading part of the Cordilleran fold and thrust belt in southwest Montana and east-central Idaho

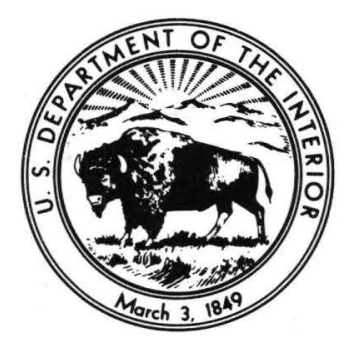




\title{
UNITED STATES DEPARTMENT OF THE INTERIOR
}

\author{
WILLIAM P. CLARK, Secretary
}

\section{GEOLOGICAL SURVEY}

Dallas L. Peck, Director

Library of Congress Cataloging in Publication Data

United States. Geological Survey.

Ruppel, Edward Thompson, 1925-

The thrust belt in southwest Montana and east-central Idaho.

(Geological Survey Professional Paper ; 1278)

Bibliography: $41 \mathrm{p}$.

Supt. of Docs. No.: I 19.16

1. Thrust faults (Geology)-Montana. 2. Thrust faults (Geology)-Idaho.

I. Lopez, David A. II. Title. III. Series.

QE606.5.U6R87

1984

$557.86^{\prime} 6$

For sale by the Branch of Distribution, U.S. Geological Survey 604 South Pickett Street, Alexandria, VA 22304 


\section{CONTENTS}

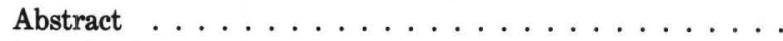

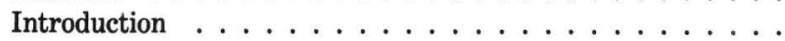

Organization of this report $\ldots \ldots \ldots \ldots$

Summary of earlier studies . . . . . . . . . . .

Acknowledgments . . . . . . . . . . . . . . .

Rocks and structure east of the thrust belt ........

Major thrust plates and thrust systems of the region ..

Frontal fold and thrust zone and the leading edge of the

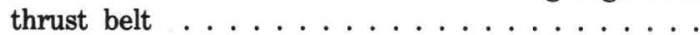

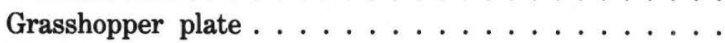

Medicine Lodge plate .............

\begin{tabular}{r|} 
Page \\
1 \\
1 \\
3 \\
5 \\
5 \\
5 \\
7 \\
7 \\
14 \\
21
\end{tabular}

Summary of contrasts in autochthonous and allochthonous rocks and paleogeographic speculations ........

Beaverhead Formation . . . . . . . . . . . . .

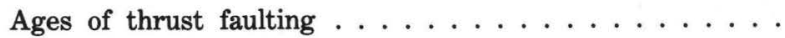

Relation of the thrust belt in southwest Montana to the Sixteenmile thrust zone and to other thrust plates in west-central Montana ...............

Summary and interpretation of structural relations in the thrust belt in southwest Montana and east-central Idaho .

Mineral resources in the thrust belt ...........

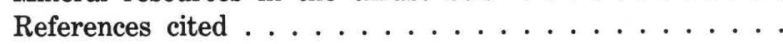

Page 28 31

\section{ILLUSTRATIONS}

Page

Plate 1. Map of principal known and inferred faults in southwest Montana and east-central Idaho . . . . . . . . In pocket

FIGURE 1. Index map of southwest Montana and east-central Idaho . . . . . . . . . . . . . . . . . . . . . . . .

2. Generalized stratigraphic column in southwest Montana, east of the thrust belt $\ldots \ldots \ldots \ldots$

3. Schematic map of major folds and faults east of the thrust belt in southwest Montana . . . . . . . . . . . 8

4. Sketch map showing major parts of the thrust belt in southwest Montana and east-central Idaho . . . . . . . 9

5. Sketch map showing frontal fold and thrust zone of thrust belt in southwest Montana . . . . . . . . . . . 11

6. Generalized stratigraphic column in the frontal fold and thrust zone, southwest Montana . . . . . . . . . . . . 12

7. Sketch map of the Grasshopper thrust plate, southwest Montana . . . . . . . . . . . . . . . . . . 16

8. Generalized stratigraphic column in the Grasshopper thrust plate, southwest Montana . . . . . . . . . . . . 18

9. Composite stratigraphic column of Cambrian rocks at the mouth of Warm Springs Creek, near Jackson, Montana . 19

10. Sketch map showing the Medicine Lodge thrust plate, southwest Montana and east-central Idaho . . . . . . . . 22

11. Generalized stratigraphic column in the Medicine Lodge thrust plate, southwest Montana and east-central Idaho . 24

12. Sketch map showing distribution of the Yellowjacket Formation in east-central Idaho . . . . . . . . . . . . 25

13. Summary columns of autochthonous and allochthonous stratigraphic sequences, southwest Montana and east-central Idaho 29

14. Sketch map showing relation of the thrust belt to the Targhee uplift . . . . . . . . . . . . . . . .

15. Cross sections of thrusts in structural and sedimentary basins overridden by thrust plates, south edge of Belt basin; in southwest Montana; and along the leading edge of the thrust belt in southwest Montana . . . . . . . . . 



\title{
THE THRUST BELT IN SOUTHWEST MONTANA AND EAST-CENTRAL IDAHO
}

\author{
By EdWARd T. RuPPel and DAvid A. LOPEZ
}

\section{ABSTRACT}

The leading edge of the Cordilleran fold and thrust belt in southwest Montana appears to be a continuation of the edge of the Wyoming thrust belt, projected northward beneath the Snake River Plain. Traces of the thrust faults that form the leading edge of the thrust belt are mostly concealed, but stratigraphic and structural evidence suggests that the belt enters Montana near the middle of the Centennial Mountains, continues west along the Red Rock River valley, and swings north into the Highland Mountains near Butte.

The thrust belt in southwest Montana and east-central Idaho includes at least two major plates-the Medicine Lodge and Grasshopper thrust plates each of which contains a distinctive sequence of rocks, different in facies and structural style from those of the cratonic region east of the thrust belt. The thrust plates are characterized by pervasive, open to tight and locally overturned folds, and imbricate thrust faults, structural styles unusual in Phanerozoic cratonic rocks. The basal décollement zones of the plates are composed of intensely sheared, crushed, brecciated, and mylonitized rocks; the décollement at the base of the Medicine Lodge plate is as much as $\mathbf{3 0 0}$ meters thick.

The Medicine Lodge and Grasshopper thrust plates are fringed on the east by a 10 - to 50-kilometer-wide zone of tightly folded rocks cut by imbricate thrust faults, a zone that forms the eastern margin of the thrust belt in southwest Montana. The frontal fold and thrust zone includes rocks that are similar to those of the craton, even though they differ in details of thickness, composition, or stratigraphic sequence. The zone is interpreted to be one of terminal folding and thrusting in cratonic rocks overridden by the major thrust plates from farther west.

The cratonic rocks were drape-folded over rising basement blocks that formed a foreland bulge in front of the thrust belt. The basement blocks are bounded by steep faults of Proterozoic ancestry, which also moved as tear faults during thrusting, and seem to have controlled the curving patterns of salients and reentrants at the leading edge of the thrust belt.

Radiometric and stratigraphic evidence shows that the thrust belt was in its present position by about 75 million years ago.

\section{INTRODUCTION}

The North American Cordilleran fold and thrust belt has long been known to extend through southwest Montana and east-central Idaho, perhaps mainly because thrust faults were described in this region more than 50 years ago. But the results of thrusting have remained little understood, and even the eastern limit of thrust-faulted rocks has been so uncertain that only a vague line connecting the Medicine Lodge thrust of Kirkham (1927, p. 26-27) to the disturbed belt of westcentral Montana could be drawn. Because only the Medicine Lodge thrust was believed to have appreciable regional significance, and because little was known of the rocks and structure of east-central Idaho, stratigraphic interpretations throughout the region were made without considering the effects of tectonic overlapping of different facies.

Recent field studies have led to much greater, although still incomplete, understanding of the extent and results of thrust faulting in this region. These studies show that the thrust belt reaches from its leading edge in southwest Montana westward to the Idaho batholith in central Idaho, a width of more than $200 \mathrm{~km}$, and suggest, too, that the belt includes a still uncertain number of major thrust plates, each characterized by a unique sequence of rocks.

This report discusses the eastern part of the thrust belt, from its leading edge against cratonic rocks that are not cut by major thrust faults in southwest Montana, westward to west of the Lost River Range in Idaho (fig. 1). In this region, the thrust belt includes two major thrust plates-the Medicine Lodge and Grasshopper plates-and an easternmost frontal zone of complex folding and terminal thrusting (fig. 4). The Medicine Lodge thrust plate and thrust system $^{1}$ were described in an earlier report (Ruppel, 1978) that did not make clear the relation of the Medicine Lodge thrust plate and the more eastern parts of the thrust belt, because the relation was not known then. The Proterozoic sedimentary rocks that form a major part of the Medicine Lodge thrust plate were also described

\footnotetext{
${ }^{1}$ As used in this report, "thrust plate" refers to the rocks that have been tectonically transported on the thrust that has the same name. Each thrust plate is composed of rocks that differ from those in other thrust plates or in adjacent or nearby regions that are not thrust-faulted, in some combination of sequence, lithology, thickness, and age. The rocks of each thrust plate thus are an assemblage unique to that plate. If a thrust plate is large enough, units of sedimentary rocks may change facies within the plate, but the assemblage nonetheless remains unique to that thrust plate.

A "thrust system" is a network of interrelated flat faults that both bound and cut a thrust plate. It includes the major zone of shearing, or décollement zone, at the base of the thrust plate, and the complex of relatively small, interlacing imbricate thrust faults that cut the thrust plate and dip down into the basal décollement zone.
} 


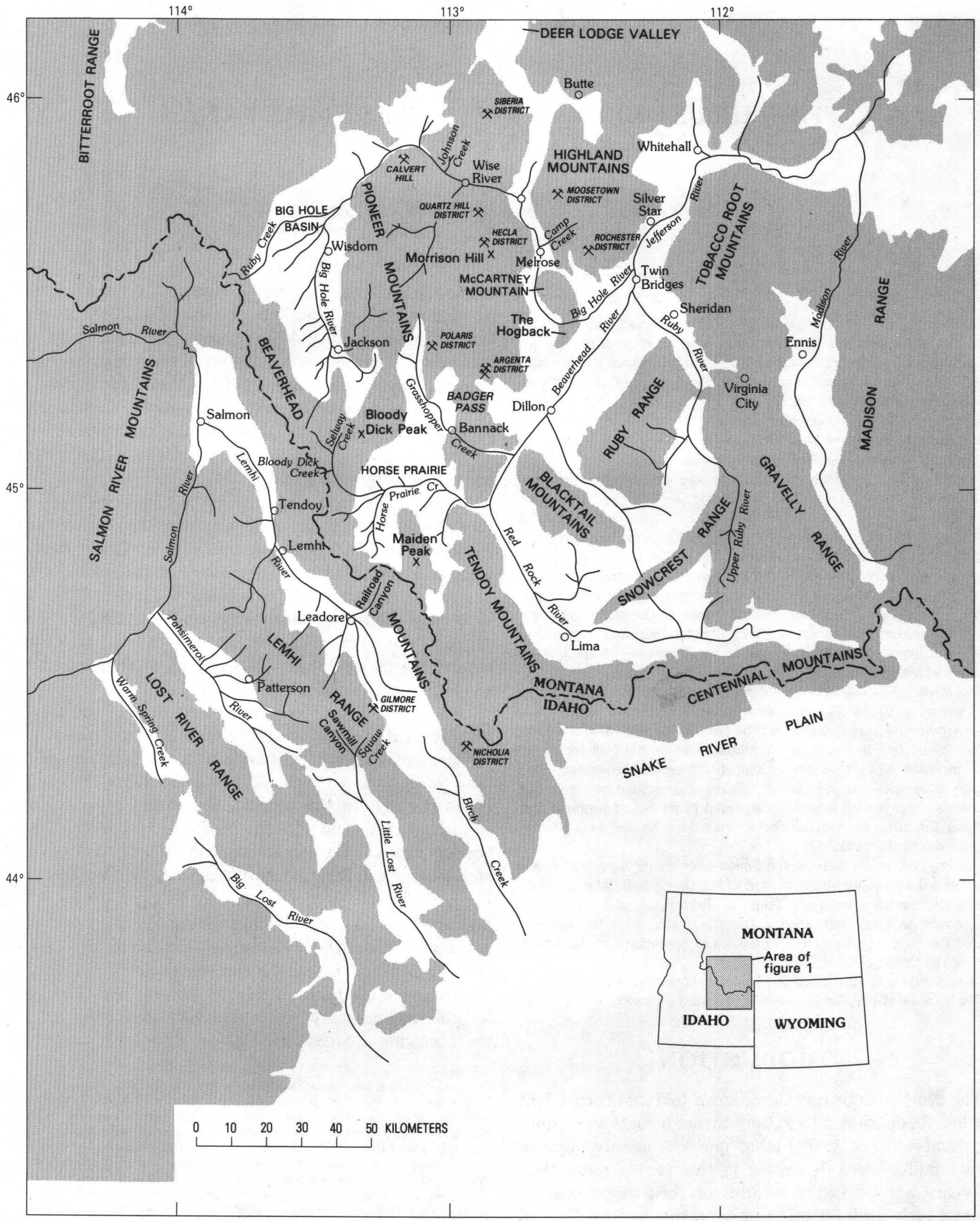

FIGURE 1.-Index map of southwest Montana and east-central Idaho. Mountain ranges shaded. Base from U.S. Geological Survey 1:500,000 Idaho, 1968, and Montana, 1966. 
in an earlier report (Ruppel, 1975), in which the suggestion was made that these rocks and the overlying Paleozoic rocks must have been tectonically transported far east of their depositional region by regional thrusting, but the regional significance of the Medicine Lodge thrust had not been recognized then. Each of these earlier reports thus is incomplete, because the geology of the region at the time that they were written was not as well known as it is now. The reports do provide much of the information that has led to the interpretations and conclusions of this present report, however, and they should be used in conjunction with this report. In addition, detailed geologic maps of the central part of the Lemhi Range (Ruppel, 1968, 1980; Ruppel and Lopez, 1981) show the rocks and structural complexity of the Medicine Lodge thrust plate and thrust system there. The thrust plates were folded and cut by steep faults in episodes of middle and late Cenozoic block uplift and regional warping (Ruppel, 1982); and they owe their present crumpled form both to deformation that accompanied thrusting and to subsequent folding and faulting that continue to the present time.

Earlier literature on the geology of southwest Montana provides much of the stratigraphic and structural information used to support the interpretations and conclusions of this report. The rock sequences of the region, documented in these earlier reports, clearly differ from place to place, but the stratigraphic interpretations and reconstructions that accompany the reports could not consider the effects of then-unknown thrust faults. The carefully measured and described stratigraphic sections provide the basic evidence we use for separating the different parts of the thrust belt and for demonstrating the unique sequences of rocks in the different parts. However, the detailed descriptions of rock units are not repeated in this report, on the grounds that repeating them would provide only a pale copy of the earlier literature and that such lengthy stratigraphic descriptions are an unnecessary diversion here. Instead, the rock sequence of each part of the thrust belt is summarized in columnar form, with appropriate citations to earlier literature, and the principal changes from place to place are discussed as products of depositional facies changes brought together by regional thrusting. The stratigraphic columns only summarize the fundamental stratigraphic evidence for thrusting. The stratigraphic descriptions are in the earlier literature and should be studied there in their original form. The principal earlier reports are Klepper (1950), Sloss and Moritz (1951), Myers (1952), Scholten, Keenmon, and Kupsch (1955), Scholten (1957), Scholten and Hait (1962), Ross (1947, 1961, 1962a, b), Cressman and Swanson (1964), Mapel, Read, and Smith (1965), McMannis (1965), Huh (1967), Swanson (1970), Mamet,
Skipp, Sando, and Mapel (1971), Staatz (1972), Ruppel (1968, 1975, 1978), Ruppel, Ross, and Schleicher (1975), Tysdal,(1976b), Skipp and Hait (1977), and Ryder and Scholten (1973).

In this report, the geology of southwest Montana and east-central Idaho is discussed in a context of regional thrusting, and the different rock sequences of the region, which are not readily understandable in terms of facies concepts alone, are suggested to have been confused by telescoping on major thrust faults and further scrambled by imbricate thrusting within major thrust plates. Much of southwest Montana and east-central Idaho remains poorly known geologically and unmapped, however, and so knowledge of the effects of thrust faulting is far from complete. Our intent here is to summarize what is known, to suggest that two major thrust plates and a frontal zone of tight folds and imbricate thrust faults are the principal parts of the thrust belt in this region, and to suggest that the abrupt changes in composition, distribution, or stratigraphic sequence of sedimentary rocks from place to place throughout the region are a result of regional thrust faulting, which has brought closer together or overlapped sedimentary facies that originally were more widely separated.

\section{ORGANIZATION OF THIS REPORT}

Any attempt to synthesize the stratigraphy and structure of a large region, particularly in a new or different framework than that previously understood, quickly encounters problems of how to organize the available information. This report is no exception, and a guide to what we have done seems appropriate to help the reader through the report. To provide a brief description of the cratonic rocks overridden by the thrust belt, the first major section on the geology of the region deals with rocks and structure just to the east of the thrust belt in southwest Montana, an area that is reasonably well known and well described in the earlier literature. The following section describes the different parts of the thrust belt in sequence westward, from the frontal fold and thrust zone, to the Grasshopper thrust plate, and finally to the Medicine Lodge thrust plate. This section only briefly summarizes, mainly in columnar form, the descriptions from the earlier literature of rock sequences in each part of the thrust belt and briefly outlines major changes or differences in rock sequence. Those sequences which are new or which have not been adequately described before are discussed in more detail. Most of the section discusses the distribution and structure of the different parts of the thrust belt. But we would add a word of caution; it is the unique groups of rocks, bounded by thrust faults, that define the different parts of the 
thrust belt. If the descriptions of the distribution and structure of the different parts of the thrust belt are detailed and those of the stratigraphy only brief, it is because the distribution and structure are newly described here, and not because the stratigraphy is less important. Most of the rocks have been described previously, and we do not repeat those descriptions, but the stratigraphy is of fundamental importance.

The discussion of the Medicine Lodge thrust in southwest Montana and east-central Idaho includes a section on the rocks of the Proterozoic Yellowjacket Formation, beneath the Medicine Lodge thrust plate. We include discussion of the Yellowjacket and its regional relations because we interpret the Yellowjacket to be autochthonous, not transported by regional thrusts, and because it is cut off on the east by Proterozoic faults, newly described here, that were intersected by the Medicine Lodge décollement and are overlapped only slightly by the Medicine Lodge thrust plate.

The section on the parts of the thrust belt is followed by a summary of changes in the rocks from the craton across the different parts of the thrust belt, and by a partly speculative discussion of the paleogeographic and depositional setting of the sedimentary rocks before thrusting. It suggests that the Lemhi arch (Ruppel, 1978 , p. 12-14) originally separated some of the miogeoclinal rocks of the Medicine Lodge plate from those farther east, which were deposited in a seaway east of the arch and on the cratonic shelf, and which now are represented in the Grasshopper plate, in the frontal fold and thrust zone, and on the craton east of the thrust belt. Then follows a discussion of the Beaverhead Formation, deposited contemporaneously with thrusting for the most part, and of other Cretaceous rocks of the same age as the lower part of the Beaverhead Formation in and near the thrust belt.

The age and regional relations of the synorogenic Beaverhead Formation and temporally related rocks are a necessary part of an evaluation of the age of thrust faulting in southwest Montana and east-central Idaho, and their description is followed by a brief discussion on age that also incorporates the available isotope-age determinations on intrusive igneous rocks that cut the thrust belt. The isotope-age determinations show that the thrust belt in southwest Montana was in its present position by about 75 m.y. ago, and so indicate, with other evidence, that these thrusts cannot be tied directly to the younger Sixteenmile thrust zone of Robinson (1963, p. 108) or to the Montana disturbed belt farther north, a conclusion also reached by Robinson. The relations with the Sixteenmile thrust zone and with other thrust zones now recognized in west-central Montana are then discussed-but only briefly, because much of the connecting region is unmapped and the eastern part is intruded by the Boulder batholith, emplaced after thrusting.

A final summary reviews our conclusions on the thrust belt in southwest Montana and east-central Idaho and interprets its structural relations. We conclude that the Medicine Lodge thrust plate is by far the dominant, and dominating, plate of the region, and that the Grasshopper plate and the frontal fold and thrust zone, both structurally beneath the Medicine Lodge plate, reflect the response of rocks in different depositional and structural basins to overriding by the Medicine Lodge plate. The curving pattern of salients and reentrants at the leading edge of the thrust belt is interpreted to reflect, in the salients, the patterns of structural and depositional basins containing sedimentary sequences that could be thrust faulted and the patterns of Proterozoic faults with recurrent movement that controlled the margins of depositional basins indenting the cratonic margin and that moved as tear faults during thrusting. The reentrants reflect the patterns of intervening arches of cratonic crystalline rocks.

Lastly, the relation of intrusive igneous rocks and related mineral deposits to the thrust belt is discussed. The section expands and modifies conclusions reached earlier for the Medicine Lodge thrust (Ruppel, 1978, p. 18-20)-that the major thrust plates and thrust systems of the region have exerted a primary structural control both on the emplacement of intrusive igneous rocks and on the deposition of related mineral deposits.

The potential for accumulations of petroleum and natural gas in the thrust belt in southwest Montana and east-central Idaho is not discussed in this report, because, in the absence of subsurface information, we cannot add much to what has been said earlier in the report on the Medicine Lodge thrust system (Ruppel, 1978, p. 20). Clearly, the region is one of feasible source rocks, suitable reservoir rocks, and favorable structures. Recognition of the Grasshopper plate and of the structural configuration of the frontal fold and thrust zone expands the region to be explored. However, if our interpretation of the Proterozoic Yellowjacket Formation as autochthonous is correct, the region for exploration is appreciably reduced, as it is reduced also by the large areas in the Grasshopper plate that have been intruded by batholithic masses of granitic rocks. Finally, stratigraphic concepts developed in the search for petroleum and natural gas must be evaluated in a context of regional thrusting and resulting tectonic overlapping of sedimentary facies originally more widely separated. Interpretations based solely on the earlier descriptions of rock units, and on facies concepts alone, are likely to be seriously in error. 


\section{SUMMARY OF EARLIER STUDIES}

The development of knowledge and understanding of thrust faults in southwest Montana and east-central Idaho (pl. 1) has been slower than in other parts of the North American Cordilleran fold and thrust belt, and the significance of thrust faults in the region is only gradually becoming clearer. One thrust fault, the Medicine Lodge, was recognized as early as 1927 (Kirkham, 1927, p. 26-27), and thrusts in the BannackArgenta area were described in 1931 by Shenon (1931, p. 25-26). Other thrusts were recognized in mapping and stratigraphic studies in the 1950's (Klepper, 1950; Sloss and Moritz, 1951; Myers, 1952; Sloss, 1954; Scholten and others, 1955; Lowell, 1965). Sloss and Moritz (1951, p. 2156-2160) recognized the stratigraphic confusion introduced by tectonically overlapped rocks of similar age but different facies, but, in general, both they and subsequent students of the geology of the region considered the known thrust faults to be relatively minor features. The thrust belt was thought, in these earlier studies, to be only $10-20 \mathrm{~km}$ wide, largely because only a single reconnaissance geologic map and report (Umpleby, 1913) was available for the adjacent region in east-central Idaho.

Umpleby's early work in Idaho has been supplemented only in the last 20 years with more detailed geologic mapping, and his report remains a standard and necessary reference even today, particularly for information on mining and mineral resources. The more recent detailed geologic mapping has been in all three of the east-central Idaho mountain ranges (fig. 1)-the Beaverhead Mountains (Staatz, 1972, 1973, 1979; Ruppel, 1968; Lucchitta, 1966; Smith, 1961; Scholten and Ramspott, 1968; Skipp and Hait, 1977); the Lemhi Range (Hait, 1965; Ruppel, 1968, 1980; Ruppel and Lopez, 1981; Ross, 1961; Beutner, 1968); and the Lost River Range (Ross, 1947; Mapel and others, 1965; Mapel and Shropshire, 1973), and has led to greatly increased understanding of the stratigraphic and structural framework of this region. As a result, thrust faults are known to be present almost everywhere, the Medicine Lodge thrust of Kirkham (1927) has been redefined as the Medicine Lodge thrust system and thrust plate (Ruppel, 1975, 1978), and the implications and consequences of regional thrusting are becoming clearer.

Scholten, one of the most persistent students of the region, discussed some of consequences of regional thrust faulting and proposed gravitational gliding from a high area in central Idaho as a mechanism to explain regional thrusting (1968, 1973; Ryder and Scholten, 1973).

\section{ACKNOWLEDGMENTS}

This report is a product of continuing studies by the U.S. Geological Survey on the geology and mineral and energy resources in and near the thrust belt in east-central Idaho and southwest Montana. We are indebted to J. E. Harrison, C. A. Wallace, I. J. Witkind, S. S. Oriel, and the late M. R. Klepper, all of the U.S. Geological Survey; to Professor Robert Scholten of Pennsylvania State University; and to Professor H. W. Dresser of the Montana College of Mineral Science and Technology-all of whom have shared their information and interpretations and provided helpful advice.

\section{ROGKS AND STRUCTURE EAST OF THE THRUST BELT}

The rocks east of the thrust belt in southwest Montana include 1,600-1,700 m of marine rocks of Paleozoic age, deposited on the Archean crystalline rocks of the craton (James and Hedge, 1980), and a similar thickness of marine and nonmarine Mesozoic rocks (fig. 2). The Paleozoic sedimentary rocks are included in the longestablished formations of the familiar shelf sequence in western Montana, from the basal Middle Cambrian Flathead Sandstone to the Phosphoria Formation and other related Permian rocks. Mesozoic sedimentary rocks are not nearly so widespread or so uniformly represented as the Paleozoic rocks, because Triassic and Jurassic rocks thin northward onto the flanks of a small Mesozoic positive area in this region (Moritz, 1951, p. 1783-1806). The thickest and most complete sequences of Triassic and Jurassic rocks are in the Snowcrest, Gravelly, and Centennial Ranges, some distance east and north of the edge of the thrust belt. Cretaceous rocks are more widespread than the Triassic and Jurassic rocks and include, in the upper part of the Ruby River valley, a well-exposed marine and nonmarine sequence typical of the Colorado and Montana Groups (Klepper, 1950, p. 67-69).

The presence of this thick section of Cretaceous rocks just east of the thrust belt indicates that marine, lacustrine, and nonmarine rocks of late Early Cretaceous age and Late Cretaceous age were deposited widely across this region, but their relation to the temporally equivalent, synorogenic Beaverhead Formation is clouded by structural problems resulting from thrusting (Lowell and Klepper, 1953; Ryder and Scholten, 1973, p. 789). Regional relations of these Upper Cretaceous rocks are discussed in another section of this report.

The pattern of folds and faults in the Phanerozoic cratonic rocks is relatively simple, but the history of their development is complex. Major folds (fig. 3) 


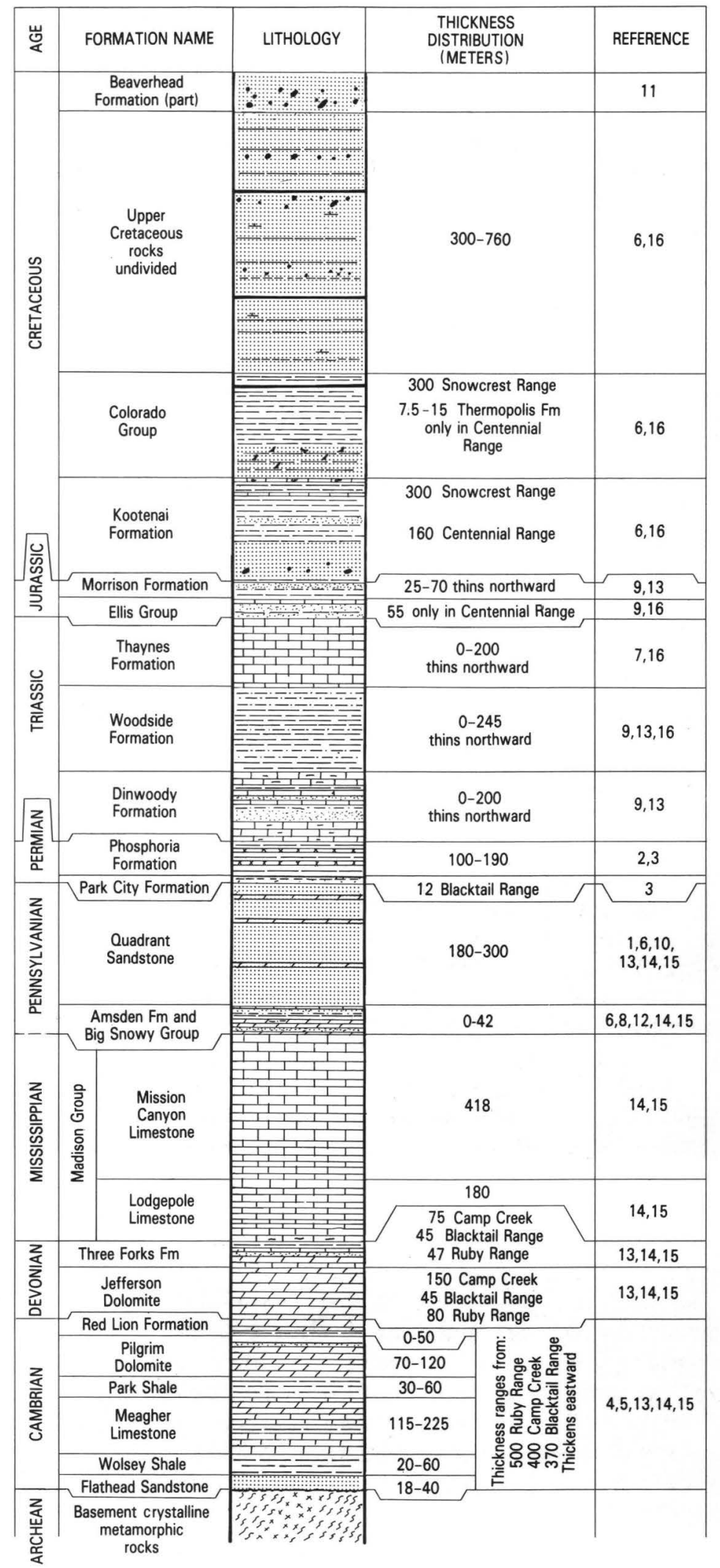

EXPLANATION

\begin{tabular}{|c|c|}
\hline 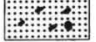 & Conglomeratic sandstone \\
\hline 杖: & Sandstone or quartzite \\
\hline 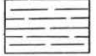 & Shale or argillite \\
\hline & Limestone \\
\hline$\frac{1}{1,1}$ & Dolomite \\
\hline $\begin{array}{ll}1 & 1 \\
7 & \\
1\end{array}$ & Argillaceous limestone \\
\hline 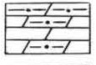 & Silty dolomite \\
\hline : & Siltstone or siltite \\
\hline $\begin{array}{l}==-1 \\
\bar{z}=\overline{=}\end{array}$ & Mudstone \\
\hline$\frac{\frac{x^{x} x x^{x}}{x x^{x} x}}{\frac{x}{x} x}$ & Chert \\
\hline 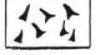 & Tuffaceous or bentonitic \\
\hline \pm+ & Calcareous \\
\hline 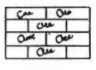 & Gastropod limestone \\
\hline 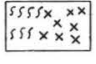 & $\begin{array}{l}\text { Metamorphic crystalline } \\
\text { rocks }\end{array}$ \\
\hline
\end{tabular}

\section{REFERENCES}
1. Axelsen (1973)
2. Cressman (1955)
3. Cressman and Swanson (1964)
4. Grant (1965)
5. Hansen (1952)
6. Klepper (1950)
7. Mann (1954)
8. Maughan and Roberts (1967)
9. Moritz (1951)
10. Robinson (1963)
11. Ryder and Scholten (1973)
12. Sando, Gordon, and Dutro (1975)
13. Scholten, Keenmon, and Kupsch (1955)
14. Sloss and Moritz (1951)
15. Tysdal $(1976 \mathrm{~b})$
16. Witkind (1976)

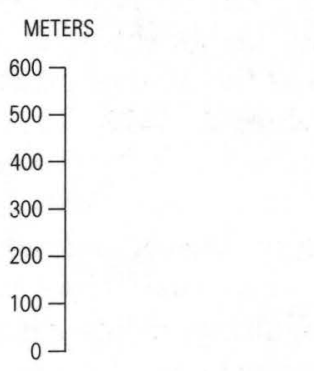

FIGURE 2.-Generalized stratigraphic column in southwest Montana, east of the thrust belt. 
started to form in Late Cretaceous time, for Upper Cretaceous rocks temporally equivalent to the Mesaverde Formation contain abundant coarse, locally derived detritus that indicates local uplift (Klepper, 1950 , p. $69,73-74)$. These ancestral folds seem to reflect fairly clearly a foreland bulge that formed by the uplift of northeast-trending basement blocks along steep reverse faults (Klepper, 1950, p. 73; Scholten, 1967, p. 11; Hadley, 1969a, b; Tysdal, 1970, p. 104-111, 1976a) and draping of the sedimentary rocks over the differentially rising basement blocks (Swanson, 1970, p. 718). The earlier mountain blocks of the foreland bulge were modified by mid-Tertiary and Quaternary block faulting to form the present mountains and basins of this region (Klepper, 1950, p. 76; Scholten, 1967; Tysdal, 1970, p. 119-124; Ruppel, 1982, p. 11-15).

The cratonic rocks in southwest Montana also are cut by a few relatively flat faults that have been interpreted to be thrusts similar to those in the thrust belt to the west (fig. 3 ).

These faults include the Snowcrest fault, on the west side of the Snowcrest Range (Klepper, 1950, p. 74), the Greenhorn-Romey fault at the north end of the Snowcrest fault (Hadley, 1969b), and the Gravelly Range thrust zone in the Gravelly Range (Mann, 1954, p. 52), and somewhat similar thrusts in the Madison Range farther east. (For example, see Witkind, 1969, p. 70-71.) They dip westward at angles of $20^{\circ}$ to $40^{\circ}$ or more, cut basement crystalline rocks as well as younger sedimentary rocks (although only a few of them have displaced the rocks more than a few hundred meters), and occur as widely spaced, single, fairly well defined structures. These faults are not much like either the major décollement thrust systems to the west or the smaller, imbricate thrusts in the frontal zone, and in this report we do not include them in the thrust belt. Probably, they are the flattened upper parts of reverse faults, or upthrusts (Prucha and others, 1965, p. 970).

\section{MAJOR THRUST PLATES AND THRUST SYSTEMS OF THE REGION}

The Cordilleran fold and thrust belt in southwest Montana and central Idaho is now known to be more than $200 \mathrm{~km}$ wide, extending from the cratonic crystalline rocks in Montana as far west as the Idaho batholith (Scholten, 1967; Dover, 1975, 1980; Ruppel, 1975, 1977, 1978; Skipp and Hait, 1977). Two major thrust plates are known in the eastern part of this region-the Grasshopper plate, which is structurally the lowest major thrust plate in southwest Montana, and the higher, much larger Medicine Lodge plate (fig. 4). These plates, and their systems of basal décollement zones and associated imbricate thrust faults, dominate the region to just west of the Lost River Range in Idaha East of the two major thrust plates, the leading part of the thrust belt is characterized by tight folds and imbricate thrust faults, but a prominent basal décollement zone, like those that floor the major plates, is not exposed.

The Grasshopper and Medicine Lodge plates are each characterized by a distinctive sequence of rocks that is more or less the same throughout each plate but which differs from the sequence of rocks in other thrust plates, from the sequence in the frontal fold and thrust zone, and from the sequence on the craton to the east. The changes in rock sequence are abrupt and take place across zones that most commonly are covered by younger volcanic rocks or surficial deposits that conceal the bases of the thrust systems. Where such basal décollement zones are exposed, they are composed of crushed, brecciated, mylonitized, and intensely sheared rocks that generally are so deformed that the original rocks cannot be recognized with much confidence (Ruppel, 1978, p. 8).

In the Grasshopper plate, the rocks above the basal décollement zone are broadly folded and are broken by imbricate thrusts that dip into the basal sheared zone. In the Medicine Lodge thrust plate the rocks above the basal décollement zone are crumpled into partly isoclinal folds that are overturned to the east, and the overturned limbs of the folds are broken by relatively small imbricate thrust faults that dip down into the basal sheared zone. The imbricate thrust faults in both of these major plates most commonly involve only the rock sequence of the major plate, but some exotic rocks differ from surrounding rocks so completely as to suggest that they have been lifted off the underlying autochthon and have been incorporated in the plate by imbricate thrusting. The imbricate thrusts are discrete faults that dip westward at angles of $10^{\circ}-20^{\circ}$, and many such faults are exposed in higher parts of the Beaverhead Mountains and Lemhi Range, where glaciation, alpine weathering, and creep have swept the thrust surfaces clean. Brecciated zones as much as 50 $m$ thick typically occur above the imbricate thrusts, and such zones control virtually all the high, nearly flat areas along the crests of the Beaverhead Mountains and Lemhi Range.

\section{FRONTAL FOLD AND THRUST ZONE AND THE LEADING EDGE OF THE THRUST BELT}

Definition.-The frontal fold and thrust zone forms the leading part of the thrust belt in southwest Montana and structurally is the lowest part of the thrust belt. 


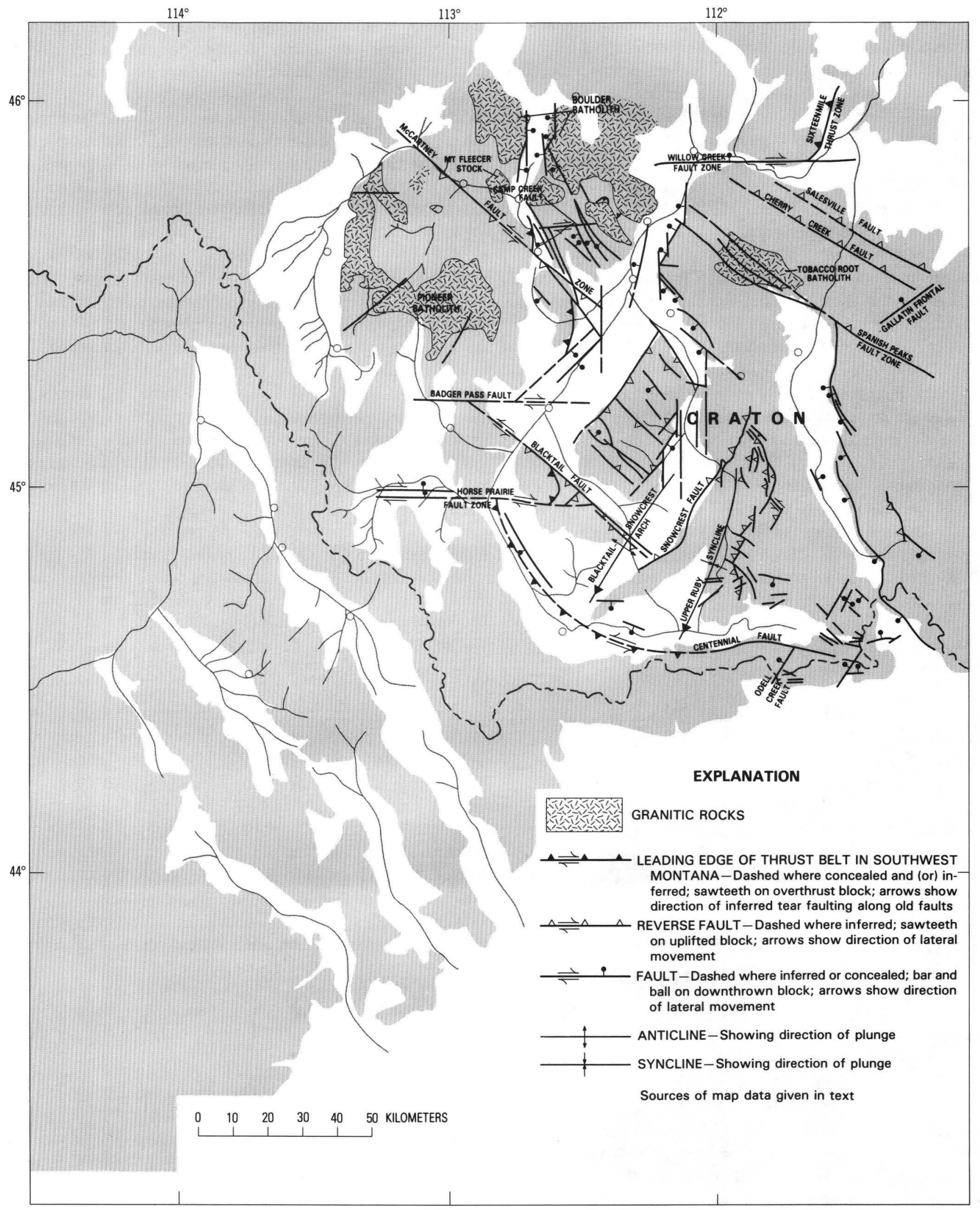

FIGURE 3.-Major folds and faults east of the thrust belt in southwest Montana. Base from U.S. Geological Survey 1:500,000 Idaho, 1968, and Montana, 1966. 


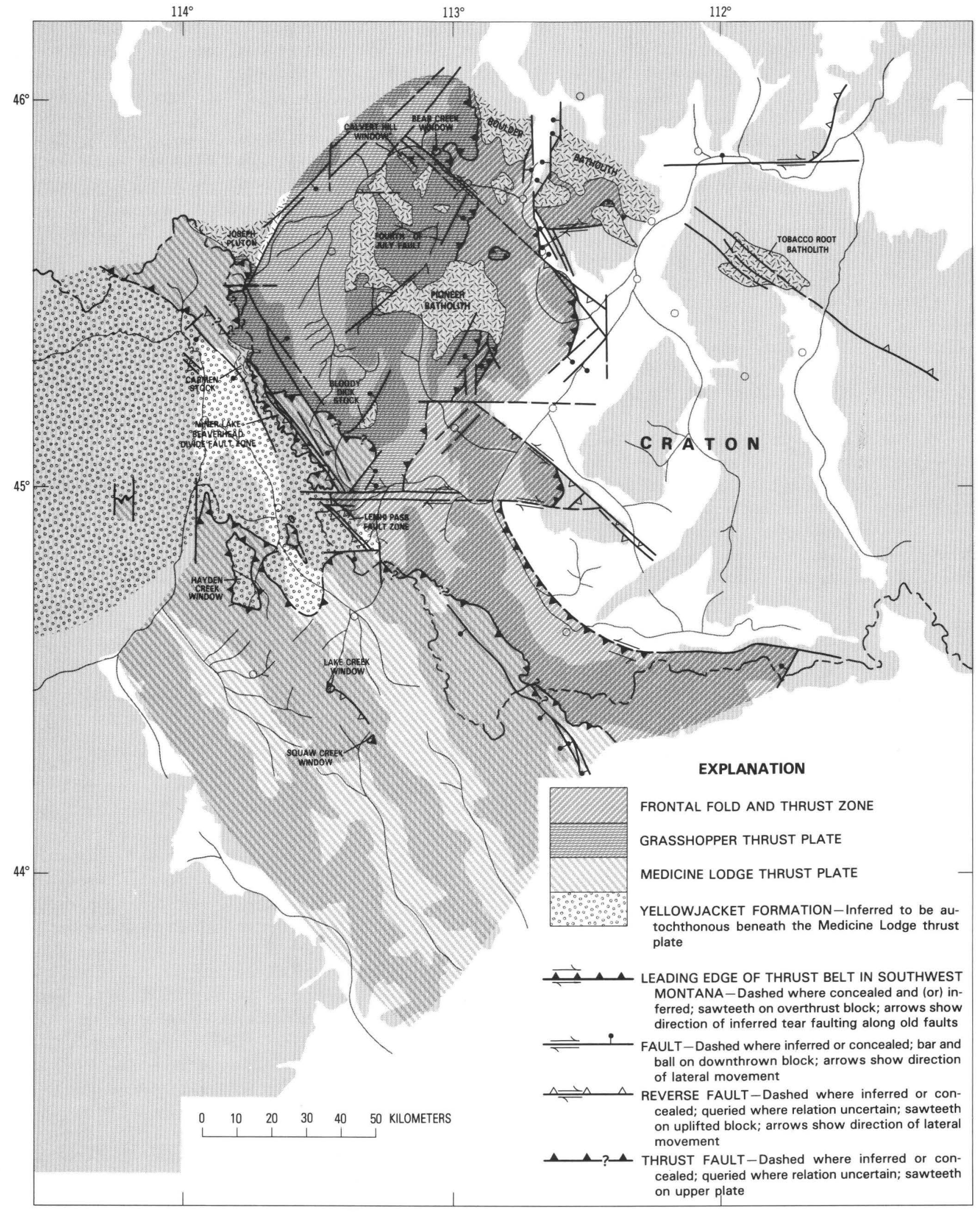

FIGURE 4. - Sketch map of the major parts of the thrust belt in southwest Montana and east-central Idaho. Base from U.S. Geological Survey 1:500,000 Idaho, 1968, and Montana, 1966. 
It is a zone of tight, partly overturned folds and multiple imbricate thrust faults that most commonly break the limbs of overturned folds. Rocks of the frontal zone resemble those of the craton, east of the thrust belt, in some ways, but include sedimentary facies originally deposited some distance farther west that now are telescoped back over the cratonic sequence by imbricate thrusting. No basal décollement is exposed at the leading edge of the frontal zone, but the western part of the zone may be floored by a basal décollement that dies out eastward in imbricate thrust faults.

The frontal zone is a zone of terminal thrusting, in which thrust-related folding and faulting gradually become less intense and less pervasive eastward, to die out against the crystalline rocks of the craton.

Distribution.-The frontal fold and thrust zone reaches northward from the Snake River Plain into the Highland Mountains just south of Butte, Mont. (fig. 5); its extension farther north is uncertain. The south part of the zone, north of the Snake River Plain, reaches from the leading edge of the thrust belt in the Centennial Mountains to east of the Beaverhead Mountains, where the zone disappears beneath the structurally higher Medicine Lodge thrust plate. Farther north, the western part of the zone disappears beneath the Grasshopper thrust plate north of Horse Prairie, but in this area salients of the frontal zone reach eastward into the Blacktail Mountains and McCartney Mountain. Windows through the Grasshopper plate show that the rocks of the frontal zone underlie the Grasshopper plate at least as far west as the central part of the Pioneer Mountains. North and east of the Pioneer Mountains, the frontal zone extends into the Highland Mountains to the edge of the Boulder batholith, and it is exposed farther west along and north of the canyon of the Big Hole River, west of Wise River, Mont., where it passes beneath the Grasshopper plate. About $10 \mathrm{~km}$ farther west, it is again exposed through a window in the Grasshopper plate in Bear Creek.

Discussion.-The interpretive line shown in figure 5 as the leading edge of the thrust belt in southwest Montana is based both on changes in structural style and on abrupt stratigraphic changes. Rocks in the frontal fold and thrust zone of the thrust belt clearly are much more complexly deformed than those east of the thrust belt, for they are tightly folded, overturned in places, and are cut by many imbricate thrust faults (Shenon, 1931, p. 25-26; Myers, 1952; Scholten and others, 1955, pl. 1; Lowell, 1965; Brumbaugh and Dresser, 1976). The zone, which includes the Tendoy allochthon of Skipp and Hait (1977, p. 511-512), appears to gradually die out eastward in progressively smaller thrust faults and less complex folds.

The complexly deformed rocks in the frontal fold and thrust zone include most of the formations of the autochthonous cratonic-shelf sequence, but there are abrupt changes in lithology, thickness, or stratigraphic sequence in the rocks of almost every system eastward across the leading edge of the thrust belt (fig. 6). The most prominent differences in the frontal zone include (1) Archean crystalline basement rocks incorporated in some imbricate thrusts (Scholten and others, 1955, pl. 1; Lowell, 1965); (2) the abrupt appearance of thrustfaulted Proterozoic sedimentary rocks north of the Camp Creek fault on the southwest flank of the Highland Mountains, including the Lahood Formation and undifferentiated rocks of the lower part of the Belt Supergroup (McMannis, 1963, p. 422-425; M. R. Klepper, oral commun., 1977); (3) the thinning and disappearance of some Cambrian rocks; (4) a thicker sequence of Mississippian rocks, which apparently include Upper Mississippian rocks not present farther east (Shenon, 1931, p. 15, 48-49; Sloss and Moritz, 1951, p. 2157; Myers, 1952, p. 8; Scholten and others, 1955, p. 365); (5) a much thicker sequence of Pennsylvanian rocks, which forms the thickest known section of the Quadrant Sandstone; and (6) the presence of Triassic formations not represented on the craton immediately northeast of the edge of the thrust belt, which form the thickest and most complete Triassic sequence in southwest Montana. These relations, and others, are discussed in more detail later in this report and are summarized in figure 13.

The leading edge of the thrust belt, defined by these structural and stratigraphic changes, forms a curving line that extends from the Snake River Plain northward to the edge of the Boulder batholith (fig. 4). The edge of the thrust belt is interpreted to be a tear along the Centennial fault as far east as the Odell Creek normal fault and, there, apparently is cut off, for only cratonic rocks, without comparable thrust faults, are known farther east (Witkind, 1977; Ruppel, 1977). Farther west, the edge of the thrust belt has been dropped down on the younger frontal fault that bounds the Tendoy Mountains on the northeast and is concealed beneath the Tertiary and Quaternary deposits along and east of the Red Rock River valley. North of the Tendoy Mountains, the frontal zone is well exposed near Clark Canyon Reservoir (Lowell, 1965), where Paleozoic sedimentary rocks and Archean crystalline rocks have been thrust across the Beaverhead Formation, and in the Blacktail Mountains, where upper Paleozoic rocks are repeatedly broken by flat, imbricate thrusts (W. C. Pecora, oral commun., 1980). The fold and thrust zone extends northeast of Dillon, Mont., into the zone of thrust faults around The Hogback and McCartney Mountain (Richards and Pardee, 1925, p. 29-30; Brumbaugh, 1973; Brumbaugh and Dresser, 1976) and from 


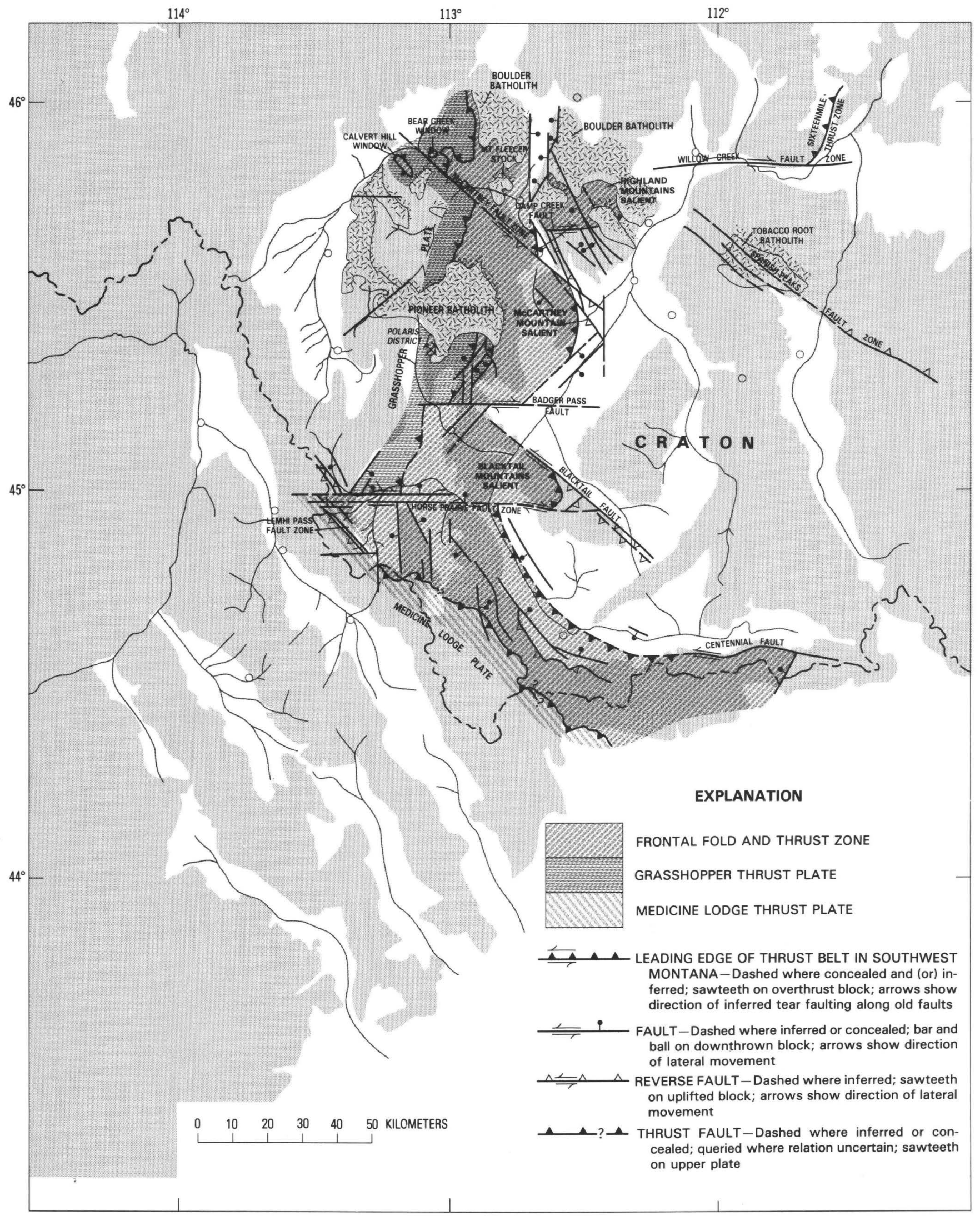

FIGURE 5.-Sketch map of frontal fold and thrust zone of the thrust belt in southwest Montana. Base from U.S. Geological Survey 1:500,000 Idaho, 1968, and Montana, 1966. 


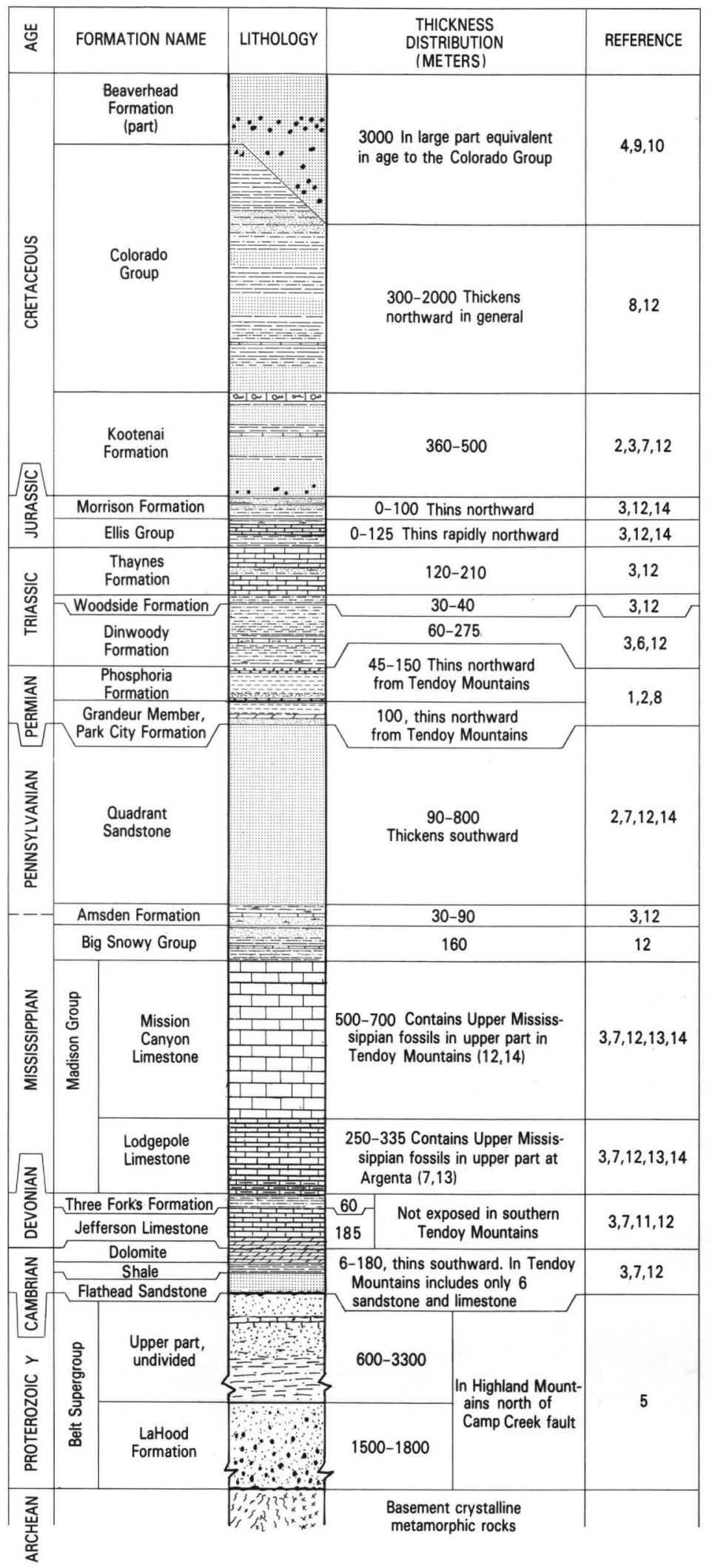

EXPLANATION

\begin{tabular}{|c|c|}
\hline 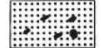 & Conglomeratic sandstone \\
\hline 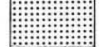 & Sandstone or quartzite \\
\hline E- & Shale or argillite \\
\hline \begin{tabular}{|l|l|}
$I^{1}$ & \\
1 & \\
\end{tabular} & Limestone \\
\hline \begin{tabular}{|l|}
$\frac{1}{1}, 1$ \\
1,1
\end{tabular} & Dolomite \\
\hline $\bar{T} \frac{\bar{T}}{\bar{T}}$ & Argillaceous limestone \\
\hline 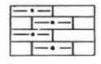 & Silty limestone \\
\hline 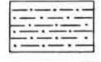 & Siltstone or siltite \\
\hline $\begin{array}{l} \\
= \\
=\end{array}$ & Mudstone \\
\hline 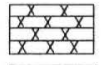 & Chert \\
\hline 125 & Tuffaceous \\
\hline$\stackrel{\perp}{\perp}$ & Calcareous \\
\hline 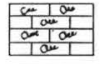 & Gastropod limestone \\
\hline 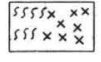 & $\begin{array}{l}\text { Metamorphic crystalline } \\
\text { rocks }\end{array}$ \\
\hline
\end{tabular}

\section{REFERENCES}

1. Cressman and Swanson (1964)

2. Fraser and Waldrop (1972)

3. Lowell (1965)

4. Lowell and Klepper (1953)

5. McMannis (1963)

6. Moritz (1951)

7. Myers (1952)

8. Richards and Pardee (1925)

9. Ryder and Ames (1970)

10. Ryder and Scholten (1973)

11. Scholten and Hait (1962)

12. Scholten, Keenmon, and Kupsch (1955)

13. Shenon (1931)

14. Sloss and Moritz (1951)

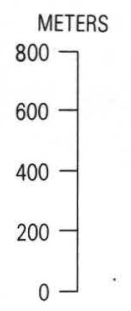

FIGURE 6.-Generalized stratigraphic column in the frontal fold and thrust zone, southwest Montana. 
there continues northward in Paleozoic and Mesozoic rocks west of Melrose (Brumbaugh, 1973). It is exposed in the Highland Mountains northeast of Melrose, where flat imbricate thrust faults cut both Proterozoic and younger rocks (M. R. Klepper, oral commun., 1978; McMannis, 1963, p. 422-425).

The Boulder batholith intrudes the frontal fold and thrust zone in the northern part of the Highland Mountains, and makes uncertain the original extension of the frontal zone farther north. The leading edge of the southwest Montana thrust belt also crosses the south margin of the Belt basin in the Highland Mountains, and so enters a region where other, somewhat younger thrust faults are present farther east (Robinson, 1963, p. 107-108), in the central Montana salient of the thrust belt (Beutner, 1977, p. 353). No basal décollement is known to be exposed along the leading edge of the frontal fold and thrust zone, but slices of crystalline metamorphic rocks in imbricate thrusts in the western part of the zone, south of the Horse Prairie fault zone, suggest that a basal décollement is present there.

Tear faults and eastward salients in the frontal fold and thrust zone.-The frontal fold and thrust zone becomes progressively wider to the north, across a series of east- and northwest-trending faults and fault zones that have moved recurrently, in different directions at different times since the Proterozoic (Ruppel, 1982, p. $5-7$; fig. 5, this report). The frontal zone widens at Horse Prairie, between the east-trending Horse Prairie fault zone (Scholten, 1981) and the northwest-trending Blacktail fault, and the leading edge of the thrust belt abruptly bulges eastward into the Blacktail Mountains salient (fig. 5). North of Dillon, Mont., the zone widens again between the Badger Pass fault and a zone of faults on the north flank of McCartney Mountain, reaching eastward from beneath the Pioneer Mountains into the McCartney Mountain salient (Brumbaugh, 1973, p. 20). Still farther north, the leading edge of the thrust belt turns abruptly east across the east-trending Camp Creek fault (McMannnis, 1963, p. 423-424), and the frontal fold and thrust zone bulges eastward in the complexly folded and thrust-faulted Proterozoic and younger sedimentary rocks that underlie the Highland Mountains south of the Boulder batholith, emplaced after thrusting. The eastern lobes of batholithic rocks, and in a crude way the edge of thrust-faulted rocks, are on the northwest projection of the northwest-trending Spanish Peaks reverse fault, extended from the Madison Range through the Tobacco Root Mountains.

Northwest-trending faults in this region commonly have been considered to be normal faults (Pardee, 1950, p. 385), but relations along the faults of this trend that form the north edges of the Blacktail and McCartney
Mountain salients suggest a more complex history. The apparently downthrown blocks north of both the Blacktail fault and the McCartney Mountain fault zone are composed of open-folded, unthrusted lower Paleozoic and Archean rocks, which are older than those in the adjacent apparently upthrown, thrust-faulted salients-a relation difficult to explain if these faults are interpreted as normal faults. Further, the Blacktail fault dips steeply southwest beneath the Blacktail Mountains (W. C. Pecora, oral commun., 1980), and not northeast as interpreted by Pardee (1950, p. 385), and the McCartney Mountain fault zone similarly seems to dip southwest beneath McCartney Mountain. The Blacktail and McCartney Mountain northwest-trending faults, therefore, cannot be interpreted as normal faults, and a more probable explanation for the relations across these faults is that they moved as oblique tears (Dahlstrom, 1977, p. 429-431) during thrusting. The tear faulting, which occurred after a long period of mainly dipslip movement that began in the Precambrian, was followed by subsequent recurrent movement as steep reverse faults in middle and late Cenozoic time to the present (Ruppel, 1982, p. 14-15). The relation on the northeast side of the Highland Mountains salient is uncertain, but the similarity of this salient to those farther south suggest that it, too, probably was originally bounded on the north by a northwest-trending tear fault, now engulfed by the Boulder batholith.

The east-trending faults - the Horse Prairie fault zone and the Badger Pass and Camp Creek faults-that are the southern boundaries of the salients have been interpreted earlier to be strike-slip or tear faults (Ruppel, 1982; Scholten, 1981; Lowell, 1965; McMannis, 1963 , p. 423-424), which reflect lateral movements during thrusting along faults established in Precambrian time. The inferred eastern projections of the Horse Prairie fault at the south boundary of the Blacktail Mountains salient and of the Badger Pass fault at the south boundary of the McCartney Mountain salient are obscured by younger rocks and by surficial deposits and have not been mapped, but both these faults suggest strike-slip movements, accompanying thrusting, where they are exposed farther west (Scholten, 1981; Ruppel, 1982, p. 5-6; Lowell, 1965). The Camp Creek fault was described by McMannis (1963, p. 424) as a relatively flat $\left(60^{\circ}\right.$ or less), north-dipping fault on which the north block had moved down in Proterozoic time. McMannis also suggested (1963, fig. 5) that the rocks north of the fault are cut by thrust faults and that those to the south are not. H. W. Smedes (written commun., 1975) interpreted the fault as a thrust, and subsequently Ruppel $(1982$, p. 5) suggested that it was one of a number of east-trending faults of Proterozoic ancestry in this 
region that were utilized as strike-slip or tear faults during thrusting.

Precambrian faults seem to have influenced and controlled the later development of eastward thrust salients and their boundary tear faults in two closely related ways. First, recurrent movements on the faults through Proterozoic and younger time (Scholten, 1981) formed small depositional basins reaching eastward onto the edge of the craton. As a result, more widespread, thicker deposits of sedimentary rocks, susceptible to thrusting, accumulated in the fault-bounded basins than in adjacent areas. The eastward thrust salients formed in these depositional basins. Second, recurrent movements probably took place on east-trending and other ancient fault zones during faulting that accompanied development of domes and basins in the foreland bulge, in front of the major thrust plates (Ruppel, 1982, p. 15; Klepper, 1950, p. 73-76). As a result, the edges of the basins were broken on steep faults that subsequently-almost simultaneously-moved as tear faults within the frontal zone.

Smaller eastward salients not as prominent as the Blacktail and McCartney Mountain salients seem to have formed in other basins between domal block uplifts in the foreland bulge (Klepper, 1950, p. 73-76; Ruppel, 1982 , p. 15). These salients are expressed in small imbricate thrusts like those that duplicate part of the cratonic sequence of Paleozoic and Mesozoic rocks as found in drill holes between uplifted cratonic blocks near Lima, Mont. (Skipp and Hait, 1977, p. 512). The thrusts near Lima are not known to be exposed at the surface; probably, they-and similar thrusts inferred to be present in other basins formed in the foreland bulge-are small, spoon-shaped terminal thrusts that end in tear faults against adjacent block uplifts.

On a regional scale, the cratonic rocks in southwest Montana are bounded by large east-trending faults, such as the Horse Prairie and Camp Creek faults, that are known or inferred to have had histories of recurrent movement. The Willow Creek fault zone is the south margin of the Belt basin and the north edge of the southwest Montana cratonic block. It clearly was a major zone of tear faulting during thrusting (Robinson, 1963, p. 108; Schmidt and others, 1977), along which thrust faults younger than any of those in southwest Montana step far eastward in the central Montana salient of the thrust belt, in the thick Proterozoic Y sedimentary rock sequence of the Belt basin (Schmidt and others, 1977; Beutner, 1977, p. 358-363). Similarly, the Centennial fault bounds the south edge of the cratonic block and is inferred to have had a history like that of the Willow Creek fault zone (Ruppel, 1982, p. 6). The thrust belt is interpreted to swing eastward on the Centennial fault, as it does on the Willow Creek fault zone, and the similarities of the two fault zones, and of other east-trending faults in southwest Montana, suggest that the western part of the Centennial fault also moved as a tear fault during thrusting, linking the thrust belt in southwest Montana to the thrust belt in western Wyoming, across the Snake River Plain.

Some of the salients and reentrants along the leading edge of the thrust belt have been discussed before, and have been attributed to different causes than suggested here. Beutner (1977) considered the causes and consequences of large, regional curves in the thrust belt and suggested that the westward reentrants are a result of thrust faults riding against buttresses of cratonic crystalline rocks and that salients reach eastward in unbuttressed regions. The southwest Montana reentrant of Beutner (1977, p. 358), which includes all of the southwest Montana thrust belt discussed here, thus was considered to be a result of buttressing. Beutner did not discuss the smaller salients in southwest Montana, except to reject an earlier explanation for the McCartney Mountain salient as a product of emplacement of the Pioneer batholith farther west (fig. 5; Brumbaugh and Hendrix, 1974; Brumbaugh and Dresser, 1976; Schmidt and others, 1977), principally because the batholithic rocks cut the thrust faults and batholithic emplacement took place after thrusting. Clearly, thrust faulting died out against cratonic crystalline rocks, but the eastward thrust salients in the frontal thrust zone seem to be a result of tear faulting during thrusting along east-trending and northwesttrending faults of Proterozoic ancestry and to be both structurally and stratigraphically controlled. Beutner's southwest Montana reentrant is flanked on the north and south by ancient east-trending faults, either known (the Willow Creek fault zone) or inferred (the Centennial fault) to have been utilized as tear faults along which thrust faults moved far to the east, past the cratonic region of southwest Montana.

\section{GRASSHOPPER PLATE}

Definition.-The Grasshopper thrust plate is structurally above the frontal fold and thrust zone and beneath the Medicine Lodge thrust plate. It is separated from the frontal zone, beneath, by a thick basal sheared zone, the Grasshopper décollement, and its south boundary is the east-trending Horse Prairie fault zone which is a Precambrian fault zone interpreted to have moved as a tear fault during thrusting at the southern margin of the plate. The east margin of the plate, in and north of the Pioneer Mountains, is marked by the Grasshopper décollement. The plate extends northward 
into west-central Montana, and its north boundary is not known; it may extend into the Sapphire thrust plate of Wallace, Ruppel, and Klepper (1979).

The Grasshopper plate is gently folded, in sharp contrast to the tight, partly overturned folding in the frontal zone, and is cut by multiple imbricate thrusts that appear to dip down into the basal décollement. The basal décollement, the imbricate thrusts cutting the plate, the thrust-related Horse Prairie tear fault at its southern boundary, and other tear faults that cut the plate together form the Grasshopper thrust system.

The rocks of the Grasshopper plate are mainly quartzite and greatly subordinate finer grained clastic rocks of the Proterozoic Missoula Group-the upper part of the Belt Supergroup-which locally are underlain by carbonate rocks of the middle part of the Belt Supergroup. The Missoula Group quartzites are overlain in a few places by Cambrian and Devonian rocks, but no younger Paleozoic or Mesozoic rocks are known to be preserved in the plate.

Distribution.-The Grasshopper thrust plate extends northward from Horse Prairie (where the south edge of the plate lies against the Horse Prairie fault) and underlies all but the east edge of the Pioneer Mountains (fig. 7). In the northern part of the Pioneer Mountains, the edge of the plate steps to the northwest along a thrust-related tear fault that is an extension of the McCartney Mountain fault zone. It is present west of Wise River, Mont., at Johnson Creek and continues northward to near the south end of the Deer Lodge Valley. The thrust plate is exposed along the east flank of the Beaverhead Mountains beneath the Medicine Lodge thrust plate, about $70 \mathrm{~km}$ west of its east edge. An erosional remnant of Proterozoic quartzites, like some of those in the Grasshopper plate, forms the top of Table Mountain, at the crest of the Highland Mountains, about $25 \mathrm{~km}$ east of the Pioneer Mountains.

Discussion.-The Grasshopper thrust plate is named for its widespread exposures in the vicinity of Grasshopper Creek and its tributaries, west of Bannack, Mont. Thrust faults of the Grasshopper thrust system were described first near Argenta, Mont. (Shenon, 1931 , p. 26, 56; Myers, 1952, p. 21-24), but the thrust system extends about $35 \mathrm{~km}$ southwest of Argenta, across the Badger Pass fault, into Horse Prairie, where it ends against the east-trending Horse Prairie fault zone (Scholten, 1981). The Grasshopper thrust plate is interpreted to have moved laterally to the east along the preexisting Horse Prairie fault (Ruppel, 1982, p. $6)$.

North of the Bannack area, the base of the Grasshopper plate is marked by the basal décollement zone of the Kelly thrust (fig. 7; pl. 1; Myers, 1952, p. 21-24), which here carried Proterozoic rocks over tightly folded and imbricate thrust-faulted Paleozoic and Mesozoic rocks. Relations in the Argenta area suggest, howèver, that the Kelly thrust is present farther east than originally mapped by Myers (1952) and that the leading part of the Grasshopper thrust plate lies along the eastern part of the Pioneer Mountains. In the Argenta area, Myers described both the Kelly thrust and, poorly exposed beneath the Kelly, the Ermont thrust, the two separated by a complexly faulted area underlain by Proterozoic and Paleozoic sedimentary rocks. Calbeck (1975, p. 70-75) and Zen (1977b) reinterpreted the relations of the Kelly thrust and suggested that it was connected, through the steep, reverse Fourth-of-July fault in the central part of the Pioneer Mountains, to the Johnson thrust still farther north (Moore, 1956, p. 6869; Fraser and Waldrop, 1972). But the Proterozoic rocks in the area between the Kelly and Ermont thrusts are similar to those elsewhere in the Grasshopper plate. Some of the faults northwest of Argenta that earlier were mapped as imbricate thrust faults between the Kelly and Ermont thrusts (Myers, 1952, pl. 1), instead, are steep faults that break the Kelly thrust plate and drop it down on the east. Accordingly, we interpret the Proterozoic rocks in the eastern part of the Argenta area also to be part of the Grasshopper thrust plate of this report, broken by steep northeast-trending faults and dropped down on the east. The rocks in this eastern, downfaulted part of the Grasshopper thrust plate are broadly folded into the north-trending Humboldt Mountain anticline (Shenon, 1931, p. 56; Myers, 1952 , p. 23), which is broken again on its southeastern flank by steep north- and northeast-trending faults, down on the west, so that the thrust plate is preserved in an arcuate northeast- and north-trending graben. Most of the basal décollement zone is concealed in the graben, but a thrust zone between Proterozoic rocks and underlying Paleozoic rocks is exposed near the Midnight mine, a few kilometers northeast of Argenta (Shenon, 1931, p. 56-57). The décollement seems to be present but concealed by surficial deposits on the east side of Humboldt Mountain, where Proterozoic rocks have been thrust across the Devonian Jefferson Dolomite and younger Paleozoic rocks (Myers, 1952, pl. 1). The field relations thus indicate that the Kelly thrust segment of the Grasshopper thrust system in the Argenta area is along the eastern face of the Pioneer Mountains and not in the central part of the range as suggested by Calbeck (1975, p. 70-75) and by Zen (1977b). The Ermont thrust of Myers (1952, p. 4-6) appears to be an imbricate thrust in the frontal thrust zone, beneath the Grasshopper thrust plate.

A short distance farther north, the Grasshopper plate 


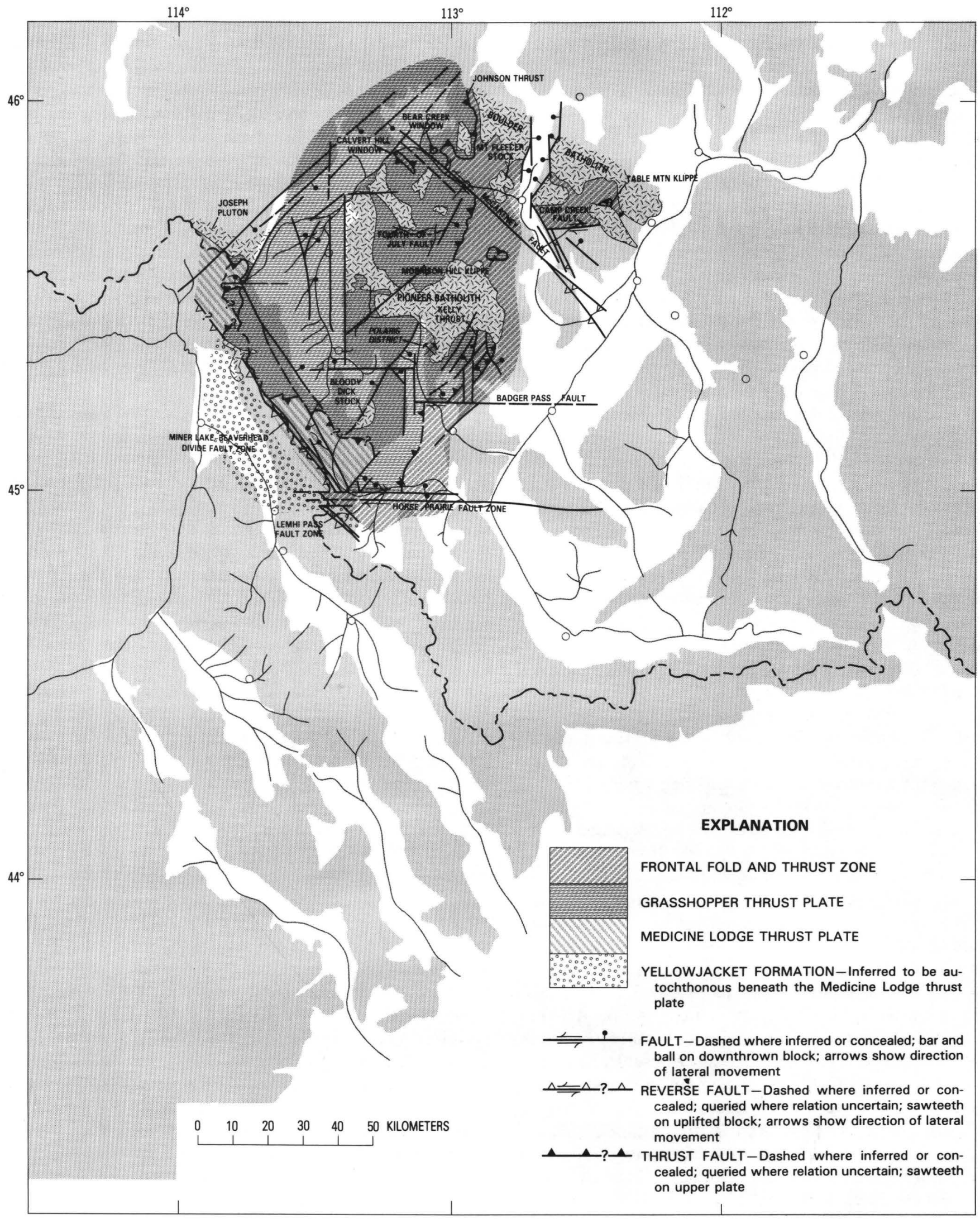

FIGURE 7.-Sketch map of the Grasshopper thrust plate, southwest Montana. 
is intruded by the postthrusting Pioneer batholith, but the plate is exposed north of the batholith in the Vipond Park area, where Proterozoic and perhaps younger sedimentary rocks are thrust across Paleozoic and Mesozoic rocks. Zen (1977b) described a klippe of Proterozoic rocks that forms the crest of Morrison Hill, south of Vipond Park, and suggested that it is an erosional remnant of the Kelly thrust plate, and so of the Grasshopper plate of this report. North of Vipond Park, on ridge crests above the Quartz Hill mining district, Proterozoic rocks are thrust over Paleozoic rocks, on a thrust fault that is essentially continuous with the Johnson thrust of Moore (1956, p. 68-70), Fraser and Waldrop (1972), and Calbeck (1975, p. 72-73), although broken in places by steep faults and by the McCartney zone of tear faulting. Farther east, the Grasshopper plate probably is represented by an erosional remnant of Proterozoic rocks of the Missoula Group on Table Mountain, in the highest part of the Highland Mountains. The Missoula Group rocks are like those of the Grasshopper plate in the Pioneer Mountains and are thrust over Belt Supergroup rocks that underlie much of the Highlands. As Zen noted (1977b), such erosional remnants suggest that the thrust plate originally was much more extensive, but the now isolated block also could have been separated from the main Grasshopper thrust plate and piggybacked eastward on the imbricate thrusts of the frontal zone-an explanation made more likely by the total absence of other remnants that might suggest a once more widespread plate.

The McCartney fault zone forms the edge of the Grasshopper plate from the exposures of the thrust plate at the north end of the Pioneer Mountains, northwest along the valley of the Big Hole River, to Johnson Creek. North of Johnson Creek, the Johnson thrust (Moore, 1956) forms the base of the plate almost to the south end of the Deer Lodge Valley, where it is concealed by Tertiary volcanic rocks and intruded by the Boulder batholith. The thrust carries Proterozoic rocks over Paleozoic and Mesozoic rocks, and much of its trace is marked by the abrupt change from Proterozoic quartzite and argillite to shale and sandstone of the Cretaceous Colorado Group (Moore, 1956; Noel, 1956; Fraser and Waldrop, 1972; Gary Benson and H. W. Dresser, written commun., 1979). The lower part of the plate locally includes thrust slices of carbonate rocks from the middle part of the Belt Supergroup (Moore, 1956, p. 10-11, 69)—the oldest Belt Supergroup rocks known in the Grasshopper thrust plate. The basal décollement of the Johnson thrust segment of the Grasshopper plate commonly is concealed by surficial deposits.

An imbricate thrust slice of dark gray thinly platy argillite and a few interbeds of fine-grained quartzite in the Grasshopper plate is exposed along Montana Highway 43 near Dickie Bridge across the Big Hole River, about $10 \mathrm{~km}$ northwest of the Wise River. These rocks closely resemble the fine-grained clastic rocks of the Colorado Group where it is exposed along the east edge of the Grasshopper plate (Moore, 1956, p. 39-44) and are not like any rocks known elsewhere in the thrust plate. They probably are Cretaceous rocks from beneath the Grasshopper plate, lifted off and carried into the plate by imbricate thrusting.

In the Beaverhead Mountains, west of the Big Hole basin, the Grasshopper plate is exposed beneath the Medicine Lodge thrust plate from the valley of Ruby Creek southward to Pioneer Creek, and in the vicinity of Bloody Dick Peak, at the south end of the Big Hole basin. Farther west, in Idaho, on the west side of the Beaverhead Mountains and in the Lemhi Range, the Medicine Lodge plate is above the Proterozoic Yellowiacket Formation, and rocks like those in the Grasshopper plate are not present.

The plate includes rocks that are not known elsewhere in southwest Montana, in a thick section of Proterozoic sedimentary rocks that is overlain by Cambrian and Devonian rocks in a few places (fig. 8). The Proterozoic sedimentary rocks are almost all part of the Missoula Group (Winston, 1973a, b, 1978), but they have not been separated into regionally consistent formations within the Missoula Group and are not well known, other than as a thick sequence of mainly palered to light-gray fine- to coarse-grained commonly feldspathic, locally conglomeratic quartzite (Myers, 1952; Moore, 1956, p. 9-15; Noel, 1956, p. 6-14; Fraser and Waldrop, 1972; Calbeck, 1975).

In the southwestern part of the Pioneer Mountains east of Jackson, Mont., the Proterozoic rocks of the Grasshopper plate include several units that, on the basis of lithologic similarity, can be correlated tentatively with formations in the Missoula Group in westcentral Montana. The uppermost Proterozoic rocks, beneath the basal sandstone of the Cambrian Flathead Sandstone, are correlated with the Garnet Range Formation and include from 0 to about $800 \mathrm{~m}$ of grayish-red to pale-red and light-brown, fine- to medium-grained, partly feldspathic, limonitic sandstone, in thin and platy beds separated by thin beds and bedding partings of grayish-red fissile argillite. Bedding surfaces are commonly spangled with white mica, and some beds are thinly laminated or cross laminated. The Garnet Range is underlain by the McNamara Formation, of uncertain thickness but possibly as much as $2,300 \mathrm{~m}$, consisting of grayish-red to pale-red, medium-grained feldspathic quartzite and quartzitic sandstone in thin and platy beds that, in part, are thinly laminated or cross laminated and are separated by grayish-red argillite in thin 


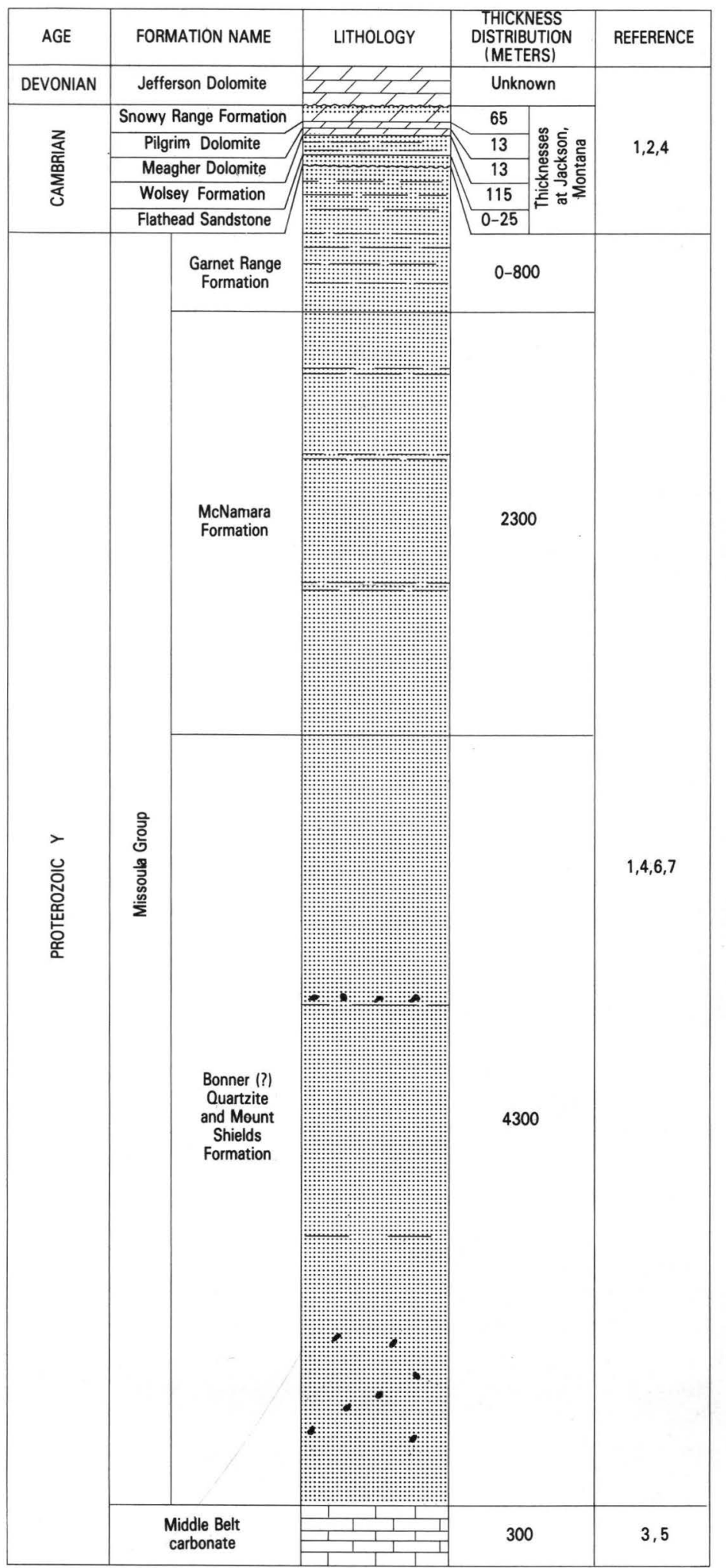

EXPLANATION

\begin{tabular}{|c|c|}
\hline 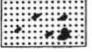 & Conglomeratic sandstone \\
\hline 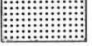 & Sandstone or quartzite \\
\hline$=-1$ & Shale or argillite \\
\hline \begin{tabular}{|l|l|l|l|}
1 & 1 \\
& 1
\end{tabular} & Limestone \\
\hline$\frac{1,1}{1,1}$ & Dolomite \\
\hline $\begin{array}{l}i \% \\
i \div \%\end{array}$ & Sandy dolomite \\
\hline$\frac{1}{11}$ & Silty dolomite \\
\hline : & Siltstone or siltite \\
\hline$=$ & Mudstone \\
\hline$\leq<$ & Dolomitic \\
\hline$\stackrel{\perp}{\perp}$ & Calcareous \\
\hline
\end{tabular}

REFERENCES

1. Coppinger (1974)

2. Fraser and Waldrop (1972)

3. Moore (1956)

4. Myers (1952)

5. Noel (1956)

6. Winston (1973a)

7. Winston (1973b)

FIGURE 8.-Generalized stratigraphic column in the Grasshopper thrust plate, southwest Montana.

beds and bedding partings and in mud-chip conglomer- thin interbeds of light-greenish-gray siliceous argillite. ates. The formation includes interbeds of greenish-gray Muscovite is common on bedding surfaces, and the fine-grained quartzite and distinctive and diagnostic $\quad$ rocks are locally mud cracked and ripple marked. 


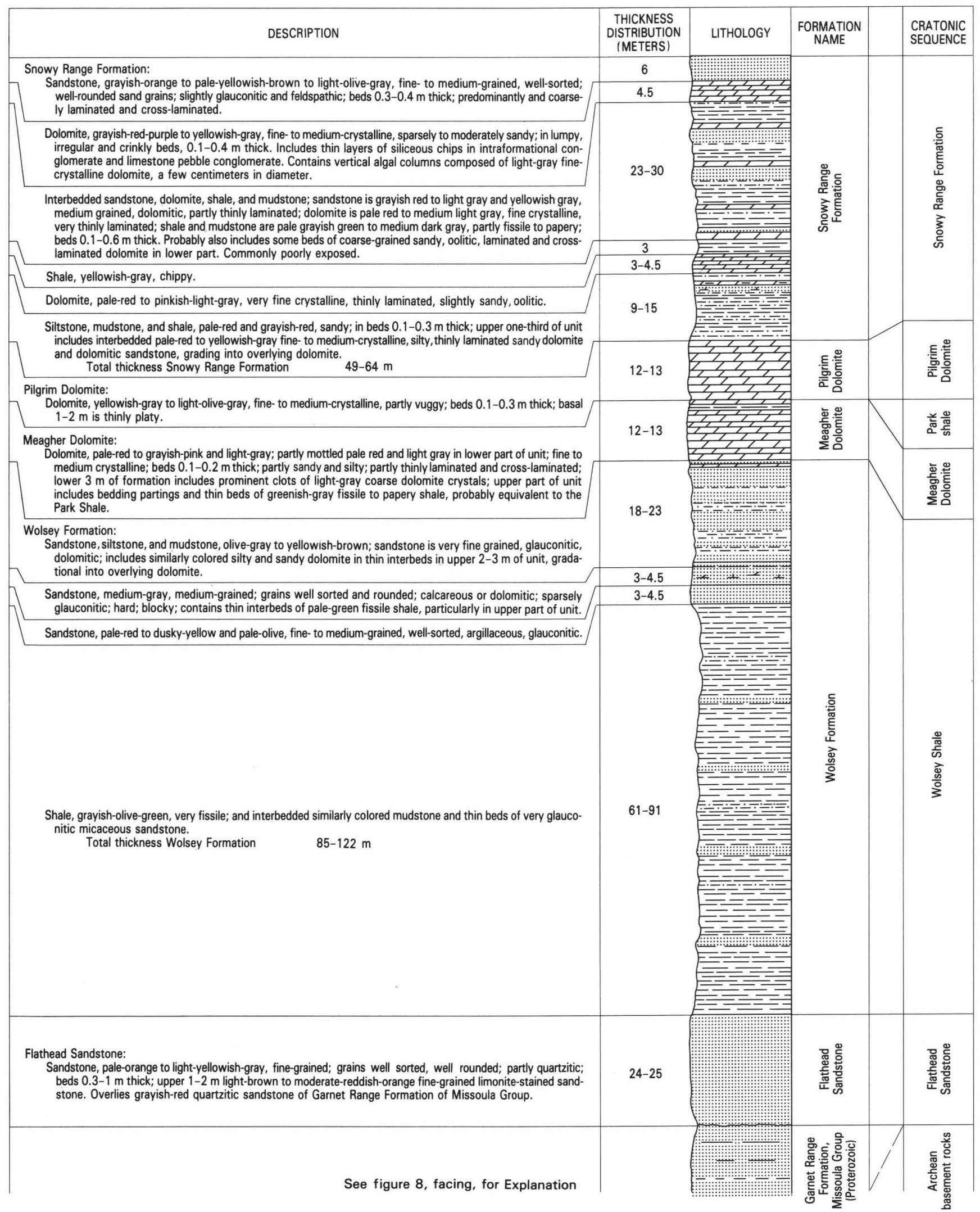

FIGURE 9.-Composite stratigraphic column of Cambrian rocks exposed at the mouth of Warm Springs Creek, near Jackson, Mont. 
A very thick and largely homogeneous sequence of quartzitic rocks beneath the McNamara Formation is thought to be equivalent to the Mount Shields Formation, or to both the Mount Shields and Bonner Formations. This thick sequence is separable into three units. The uppermost unit, perhaps as much as $3,500 \mathrm{~m}$ thick, consists mainly of pale-red to light-brownish-gray, medium-grained, partly feldspathic quartzite and quartzitic sandstone in beds 0.3 to $1 \mathrm{~m}$ thick that commonly are coarsely crossbedded. The rocks are composed of well-rounded quartz grains and commonly contain detrital magnetite that, in a few places, is concentrated in beds and crossbeds as much as $2 \mathrm{~cm}$ thick. The quartzite beds are locally separated by partings and 1- to 2-cm-thick interbeds of grayish-red argillite and mud-chip conglomerates. The lower part of the unit, about $30 \mathrm{~m}$ thick, includes abundant feldspathic grit and conglomerates that contain subrounded pebbles of granitic rocks, feldspar, and quartz. The middle unit, perhaps as much as $500 \mathrm{~m}$ thick, is greenish-gray slightly feldspathic quartzite, in beds typically less than $0.1 \mathrm{~m}$ thick. The quartzite is dominantly fine grained, but poorly sorted, and bimodal, with well-rounded medium to coarse quartz grains in the fine-grained matrix. Many beds are thinly laminated, ripple marks are common, and many beds are conspicuously mottled with limonitic-weathering crusts. The lowest unit, the lowest part of the Missoula Group exposed in the Jackson area, has an exposed thickness of about $300 \mathrm{~m}$; it consists of pale-red, medium-grained feldspathic quartzite, in beds as much as $1 \mathrm{~m}$ thick, that closely resembles the upper unit included here in the Mount Shields Formation.

Rocks similar to those included in the Mount Shields Formation and Bonner(?) Quartzite in the southwestern part of the Pioneer Mountains form most of the Grasshopper plate. The argillitic quartzites near Argenta (Myers, 1952) are part of the Garnet Range Formation, exposed beneath the Cambrian Flathead Sandstone. The only pre-Missoula Group rocks known in the Grasshopper plate are limestones, about $300 \mathrm{~m}$ thick, above the Johnson thrust in the northernmost part of the plate, thought to be part of the mid-Belt carbonate unit (Moore, 1956, p. 10-11).

The Cambrian rocks are a thin sequence of sandstone, shale, and dolomite, which appears to change westward and northward across the plate (fig. 9) (Karlstrom, 1948, p. 17-25; Myers, 1952, p. 6-7; Coppinger, 1974, p. 98-108; Zen, 1977a, p. 779). The only younger rocks known to be preserved on the Grasshopper thrust plate are dark-gray dolomites of the Devonian Jefferson Dolomite, in the south-central part of the plate south of the Polaris mining district (D. R. Zimbelman, oral commun., 1979).
Windows through the Grasshopper thrust plate indicate that rocks of the frontal thrust zone are present beneath much of the thrust plate (fig. 7). In Bear Gulch, north of the Big Hole River, the Triassic Dinwoody Formation is exposed beneath the Grasshopper plate several kilometers southwest of the edge of the plate (Gary Benson and H. W. Dresser, written commun., 1979). Farther southwest, at Calvert Hill in the northwest part of the Pioneer Mountains, Mesozoic and upper Paleozoic rocks are exposed beneath the Proterozoic rocks of the thrust plate (J. Boak, written commun., 1978). A short distance east of Calvert Hill, near the mouth of Ross Gulch on the west side of Wise River valley, Calbeck (1975, p. 71-72) recognized sheared $\mathrm{Pa}-$ leozoic carbonate rocks in an imbricate thrust slice incorporated in the Grasshopper plate, suggesting the presence of Paleozoic rocks beneath the plate here. And Mississippian rocks exposed in the Polaris mining district, in the south-central part of the Pioneer Mountains, also seem to be in a window. The regional relations therefore suggest that the Grasshopper thrust plate is underlain everywhere in at least the central and eastern parts of the Pioneer Mountains, and both northward to the Deer Lodge Valley and southward to its edge against the Horse Prairie fault zone, by $\mathrm{Pa}-$ leozoic and Mesozoic sedimentary rocks of the frontal fold and thrust zone, including rocks as young as the Cretaceous Colorado Group and the partly equivalent, synorogenic Beaverhead Formation.

Tear Faults and Salients.--Several of the tear faults that border the thrust salients in the frontal fold and thrust zone (p. 13) appear also to have influenced the pattern of Grasshopper thrusting. The east-trending Horse Prairie fault zone (Scholten, 1981) is the south edge of the Grasshopper thrust plate (fig. 7) and is a Precambrian fault that is interpreted to have moved as a tear fault during Grasshopper thrusting. The easttrending Badger Pass fault is much like the Horse Prairie fault zone, and the edge of the Grasshopper plate appears to be 10-12 km farther east on the north side of the Badger Pass fault than on the south, a relation that suggests strike-slip movement interpreted to be tearing related to Grasshopper thrusting. The fault breaks the Grasshopper plate at least as far west as the valley of Grasshopper Creek and, there, is cut off by younger, steep faults; its extension farther west, if any, is unknown. The northwest-trending McCartney Mountain fault zone on the northeast flank of the McCartney Mountain salient extends much farther northwest to control the edge of the Grasshopper thrust plate northwest of Wise River, Mont., a segment that Zen (1977b) interpreted to be a postthrusting leftlateral strike-slip fault. The fault zone extends northwest of McCartney Mountain into a narrow zone of 
northwest-trending faults mapped as thrusts in the frontal fold and thrust zone (G. D. Fraser, written commun., 1978; Swanson, 1970, pl. 27A). These faults intersect the Grasshopper thrust plate north of the Quartz Hill mining district, at the point where the basal thrust zone of the Grasshopper system abruptly turns northwest into the Johnson thrust of Fraser and Waldrop (1972), and from there trends northwest to Johnson Creek, the western part of its trace being along and beneath the valley of the Big Hole River northwest of Wise River, Mont. The McCartney Mountain fault zone, thus extended, continues even farther northwest into the Tertiary rocks at the north end of the Big Hole basin, but reconnaissance mapping indicates that the Tertiary rocks are not offset laterally as would be required in Zen's (1977b) interpretation of the fault as a postthrusting left-lateral strike-slip fault. The fault seems to be interpreted better as a Precambrian fault that has moved recurrently, including movement as a tear fault during thrusting and subsequent renewed movement in the Tertiary and Quaternary as a steep normal or reverse fault.

\section{MEDICINE LODGE PLATE}

(See Ruppel, 1978.)

Definition.-The Medicine Lodge thrust plate is structurally above the frontal fold and thrust zone south of the Horse Prairie fault zone, and farther north it is structurally above the Grasshopper thrust plate. The frontal zone and Grasshopper plate are present beneath the leading part of the Medicine Lodge plate only in the Beaverhead Mountains, however. Farther west, in Idaho, the plate is underlain by the Proterozoic Y Yellowjacket Formation, which is inferred to be autochthonous. The Medicine Lodge plate is separated from the frontal zone and Grasshopper plate, and from the Yellowjacket Formation, by a thick, basal sheared zone, the Medicine Lodge décollement. The structural top of the plate has not been mapped, but it appears to be defined by the abrupt appearance of a different sequence of rocks, which suggests the presence of another, structurally higher, major thrust plate, west of the Lost River Range in east-central Idaho (Hobbs and others, 1975; Hays and others, 1978), and by the different rocks of the White Knob allochthon of Skipp and Hait (1977, p. 507-508), farther south.

The rocks in the Medicine Lodge plate are in tight, in places almost isoclinal, folds overturned to the east. The thrust plate is cut by multiple interlacing imbricate thrust faults that dip gently down into the basal décollement, and with it form the Medicine Lodge thrust system.
The Medicine Lodge thrust plate is composed of rocks that differ radically from those in the thrust belt farther east. The rocks consist of a thick sequence of Proterozoic Y quartzitic rocks, overlain by Ordovician quartzite and dolomite, younger Paleozoic rocks that are mainly carbonates, and Triassic shale, siltstone, and sandy limestone in a few places. No younger Mesozoic rocks are known to be preserved in the plate. A few imbricate thrust slices of granitic rocks are present in the southeastern leading part of the plate; the granitic rocks are largely of early Paleozoic age but could include slices of Archean crystalline metamorphic rocks as well.

Distribution.-The Medicine Lodge thrust plate extends northwest from the edge of the Snake River Plain in east-central Idaho to the western part of the Big Hole basin in southwest Montana, and from there probably farther northwest to the edge of the Idaho batholith southwest of the Bitterroot Valley in westcentral Montana (fig. 10). The frontal part of the plate is in or just east of the Beaverhead and Bitterroot Mountains, along the Idaho-Montana line, and the plate is exposed westward to west of the Lost River Range in Idaho, an exposed width of about $130 \mathrm{~km}$.

The basal sheared zone of the Medicine Lodge thrust system is widely exposed in the Beaverhead Mountains, in the northern part of the Lemhi Range, and in windows through the thrust plate in the central part of the Lemhi Range. It is exposed in a few places beneath erosional remnants of the Medicine Lodge plate in the Salmon River Mountains north and west of Salmon, Idaho.

Discussion.-The Medicine Lodge thrust fault was first recognized by Kirkham (1927, p. 26-27), and for many years has been recognized as the principal thrust fault system in southwest Montana and east-central Idaho (Scholten and others, 1955, p. 382; Ruppel, 1978). Kirkham described the fault as a major structural feature and indicated that it extended far north of the area he mapped. Later mapping has extended the fault, as Kirkham predicted, and has been entirely consistent with the naming concept of a major thrust separating rocks of very different character. The stratigraphic significance of abrupt lithologic changes across the fault was recognized first by Sloss and Moritz (1951, p. 21562160), and was discussed by Scholten, Keenmon, and Kupsch $(1955$, p. 383), and by Ruppel $(1975,1978)$. The Medicine Lodge thrust system and the rocks in the Medicine Lodge thrust plate have been described recently (Ruppel, 1977, 1978), and so are only summarized in this report. The Medicine Lodge thrust plate includes the Lemhi stack of allochthons of Skipp and Hait (1977, p. 508-512) in the southernmost parts of the 


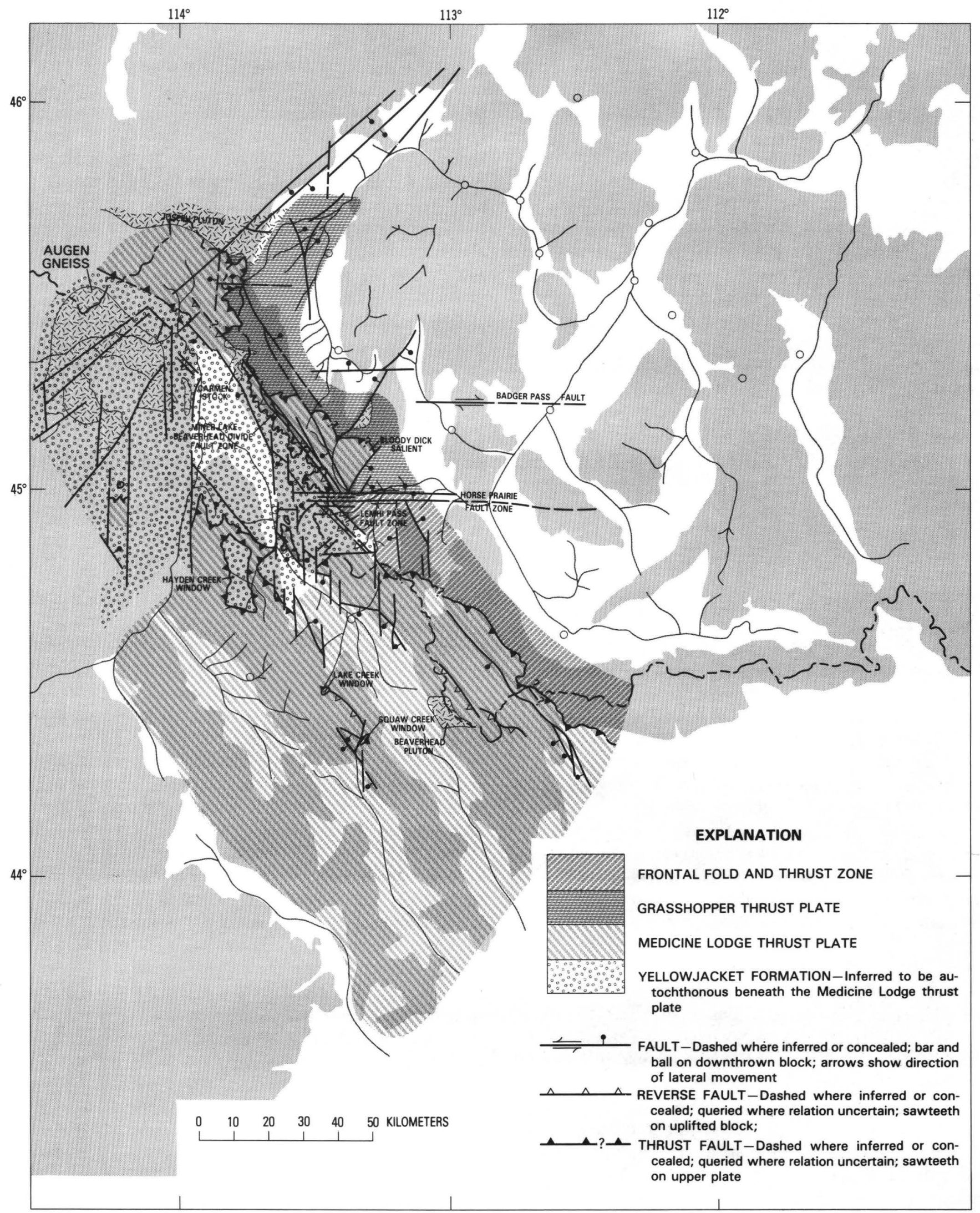

FIGURE 10.-Sketch map of the Medicine Lodge thrust plate, southwest Montana and east-central Idaho. 
Beaverhead Mountains and the Lemhi and Lost River Ranges.

The Medicine Lodge thrust system (fig. 10) extends northwest from Medicine Lodge Creek, Idaho, into and beyond the Big Hole Basin in Montana (Ruppel, 1978). The fault system is widely exposed in east-central Idaho (Ruppel, 1978, p. 2-9) and is now known to crop out on the west flank and crest of the Beaverhead Mountains, east of Salmon, Idaho, and in the Salmon River Mountains farther west. The fault zone probably is present among the flat faults described by Berg (1977, p. 27) in the southern part of Ravalli County, Mont., northwest of the Salmon, Idaho, region, and from there continues northwest to the edge of the Idaho batholith, emplaced after thrusting.

In the Lemhi Range and Beaverhead Mountains, the basal zone-the Medicine Lodge décollement-is well exposed in a few places and is an intensely sheared, brecciated, and partly mylonitized zone that is $100-300$ $\mathrm{m}$ thick. Above the basal zone, the rocks of the Medicine Lodge plate are tightly folded into overturned folds, asymmetric to the east, and are broken by closely spaced interlacing imbricate thrusts (Ruppel, 1968, 1980; Ruppel and Lopez, 1981).

The rocks in the Medicine Lodge plate (fig. 11) differ radically and abruptly from those in the thrust belt farther east and include a thick sequence of Proterozoic $\mathrm{Y}$ sedimentary rocks, overlain by Ordovician and younger Paleozoic quartzite, dolomite and limestone, and shale (Ruppel, 1978, p. 6-12). Some slices of granitic rocks are incorporated in the eastern part of the plate (Ruppel, 1978, p. 16-18). The Proterozoic Y sedimentary rocks are miogeoclinal rocks of the Lemhi Group, Swauger Formation, and Lawson Creek Formation (Ruppel, 1975; Hobbs, 1980), rather than those of the Belt Supergroup. They are in turn overlain by Proterozoic Z(?), Cambrian, Ordovician, and Silurian rocks and by a thick sequence of younger Paleozoic rocks different in most respects from the sequence east of the Medicine Lodge plate. The only Mesozoic rocks in the Medicine Lodge plate are those of the Triassic Dinwoody Formation.

These rocks all are above the Proterozoic Y Yellowjacket Formation, which is inferred to be autochthonous, beneath the Medicine Lodge thrust plate.

Relations of the Yellowjacket Formation Beneath the Medicine Lodge Thrust.-The Yellowjacket Formation underlies the Medicine lodge thrust plate throughout most of east-central Idaho. The upper contact of the formation everywhere is the Medicine Lodge décollement, no base is exposed, and no normal sedimentary contacts of Yellowjacket with other rocks are known in this region. The formation has been interpreted to be autochthonous (Ruppel, 1978, p. 8-9) because, in most places, the rocks of the Yellowjacket are only slightly deformed or exhibit a different style of deformation; the differences in deformation suggest that the Yellowjacket has not been tectonically transported by thrusting like the overriding, intricately folded and faulted rocks in the Medicine Lodge plate.

The Yellowjacket Formation disappears abruptly in the Beaverhead Mountains, more or less along the Idaho-Montana State line. East of Salmon, Idaho, the formation is cut off by the Miner Lake-Beaverhead Divide zone of reverse faults (figs. 10, 12; Mackenzie, 1949, p. 34; Anderson, 1957, p. 35-36, 1959, p. 47-49; Tucker, 1975, p. 136-146; Ruppel, 1978, p. 4-5, 8), and farther east, on the east side of the Beaverhead Mountains, the Medicine Lodge thrust plate is underlain by the Missoula Group rocks of the Grasshopper plate, and not by the Yellowjacket Formation as farther west. The Grasshopper plate is in turn underlain by Paleozoic and Mesozoic rocks that rest on Archean crystalline basement rocks (fig. 8), and the Yellowjacket does not seem to be present at depth. Farther south, in the central part of the Beaverhead Mountains, the Yellowjacket is widely exposed in and south of Lemhi Pass (Staatz, 1972, 1973, 1979) beneath the Medicine Lodge thrust plate but apparently is cut off on the east by northwesttrending steep faults of the Lemhi Pass fault zone, which is an offset extension of the Miner LakeBeaverhead Divide zone, across the Horse Prairie fault zone. East of this area, only crystalline basement rocks are present, overlain by Paleozoic and Mesozoic rocks in the frontal fold and thrust zone. In the southern part of the Beaverhead Mountains, the Yellowjacket Formation is not exposed and probably is not present at depth beneath the range because widespread thrust slices of granitic intrusive rocks suggest that they (rather than Yellowjacket rocks) are present at relatively shallow depth. The fault-bounded eastern limit of the formation, if it exists here, probably is on or just west of the southwest front of the range.

In the central part of the Lemhi Range, west of the Beaverhead Mountains, the Yellowjacket Formation is exposed in windows in the Medicine Lodge plate as far south as Squaw Creek (fig. 10; Ruppel, 1978, p. 4; Ruppel and Lopez, 1981), about $80 \mathrm{~km}$ south of Lemhi Pass.

In all of these areas of exposure, the Yellowjacket is composed of very fine grained to medium-grained feldspathic quartzite and siltite that does not differ appreciably either lithologically or in thickness from the formation in other areas farther west. There are no changes along the present east edge of the Yellowjacket Formation that suggest nearness to a depositional edge, and that part of the formation now preserved in eastcentral Idaho appears to have been deposited in the central part of the Yellowjacket depositional basin 


\begin{tabular}{|c|c|c|c|c|c|}
\hline AGE & \multicolumn{2}{|c|}{ FORMATION NAME } & LITHOLOGY & $\begin{array}{l}\text { THICKNESS } \\
\text { DISTRIBUTION } \\
\text { (METERS) }\end{array}$ & REFERENCE \\
\hline TRIASSIC & \multicolumn{2}{|c|}{ Dinwoody Formation } & & 36 Southern Beaverhead Mtns, & 4,9 \\
\hline PERMIAN & \multicolumn{2}{|c|}{$\begin{array}{l}\text { Phosphoria Formation } \\
\text { and older rocks }\end{array}$} & 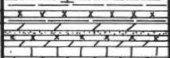 & $\begin{array}{c}300 \text { Central Beaverhead Mtns } \\
55-100\end{array}$ & $2,4,14,26,27$ \\
\hline \multirow{4}{*}{ 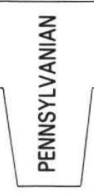 } & \multicolumn{2}{|c|}{$\begin{array}{l}\text { Snaky Canyon } \\
\text { Formation }\end{array}$} & 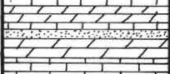 & $\begin{array}{c}400-1300 \\
\text { Thickens southward }\end{array}$ & $\begin{array}{c}1,2,4,9,15 \\
25,26,27\end{array}$ \\
\hline & \multirow{2}{*}{\multicolumn{2}{|c|}{$\begin{array}{l}\text { Bluebird Mountain Fm } \\
\text { Surrett Canyon Fm } \\
\text { and Big Snowy GP }\end{array}$}} & $1=\frac{1}{3}$ & $0-105$ & 27 \\
\hline & & & 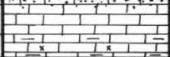 & $\begin{array}{c}70 \text { Lemhi Range } \\
120-260 \text { Beaverhead Mountains }\end{array}$ & $\begin{array}{c}7,11,15,26 \\
4,24,25\end{array}$ \\
\hline & & outh Creek Fm & $\begin{array}{lll}1 & 1 \\
1 & 1 & 1\end{array}$ & $90-200$ & $7,11,26$ \\
\hline \multirow{3}{*}{$\begin{array}{l}\frac{z}{a} \\
\frac{0}{0} \\
\frac{2}{W} \\
\text { W } \\
\frac{N}{\Sigma}\end{array}$} & \multicolumn{2}{|c|}{ Scott Peak Formation } & | & $600-700$ & $7,11,15,26$ \\
\hline & \multicolumn{2}{|c|}{ Middle Canyon Fm } & It, $1 \frac{1}{12}, 1,1$ & $150-200$ & $7,10,15,26$ \\
\hline & \multicolumn{2}{|r|}{$\begin{array}{l}\text { McGowan Creek } \\
\text { Formation }\end{array}$} & 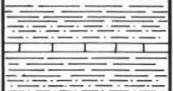 & $\begin{array}{l}\text { 40-120 Beaverhead Mountains } \\
80-150 \text { Southern Lemhi Range } \\
120-1000 \text { Lost River Range }\end{array}$ & $7,11,15,21,26$ \\
\hline \multirow[t]{2}{*}{$\begin{array}{l}z \\
\sum_{0}^{z} \\
\text { 岁 }\end{array}$} & \multicolumn{2}{|r|}{$\begin{array}{l}\text { Jefferson } \\
\text { Dolomite }\end{array}$} & 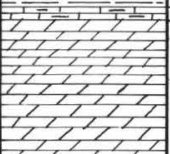 & $\begin{array}{c}\text { 15-90 Thickens westward } \\
60-300 \text { Beaverhead Mountains } \\
90-820 \text { Lemhi Range } \\
600-900 \text { Lost River Range. } \\
\text { Includes up to } 400 \text { Grandview } \\
\text { Dolomite in Lost River Range }\end{array}$ & $\begin{array}{r}14,15,18,23 \\
9,10,13,14 \\
15,18,22,24\end{array}$ \\
\hline & \multicolumn{2}{|c|}{ channel sandstone } & 1,i, , , & $\begin{array}{l}0-50 \text { Locally Lemhi and } \\
\text { Lost River Ranges }\end{array}$ & $3,17,22$ \\
\hline \multirow{4}{*}{ 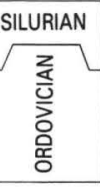 } & \multicolumn{2}{|r|}{$\begin{array}{l}\text { Laketown } \\
\text { Dolomite }\end{array}$} & 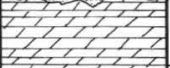 & $\begin{array}{l}0-60 \text { Lemhi Range. Thins to east } \\
\text { and north. } 400 \text { Lost River Range }\end{array}$ & $\begin{array}{l}15,18 \\
11,12\end{array}$ \\
\hline & \multicolumn{2}{|c|}{ Saturday Mountain Fm } & दी, & $0-350$ Thins to east and south & $12,13,14,17$ \\
\hline & \multicolumn{2}{|r|}{ Kinnikinic Quartzite } & & $0-300$ Thins to East & $4,8,17,22,23$ \\
\hline & \multicolumn{2}{|c|}{ Summerhouse Formation } & $1,1,7$ & $0-300$ & $8,10,17,19$ \\
\hline \multirow{2}{*}{ 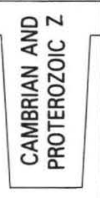 } & \multicolumn{2}{|c|}{ Wilbert Formation } & $\bullet . .:$ & 0-300 Possibly partly Cambrian & 19 \\
\hline & \multirow{2}{*}{\multicolumn{2}{|c|}{$\begin{array}{l}\text { Lawson Creek Formation } \\
\text { Swauger } \\
\text { Formation }\end{array}$}} & $-3--=$ & $\begin{array}{l}0-1200 \text { in Lost River } \\
\text { Range and Salmon River Mtns }\end{array}$ & 6 \\
\hline \multirow{7}{*}{ 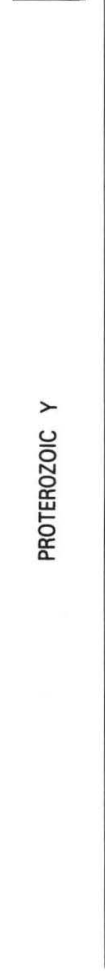 } & & & & $\begin{array}{l}\text { Maximum thickness } \\
3100\end{array}$ & 16 \\
\hline & \multirow{5}{*}{ 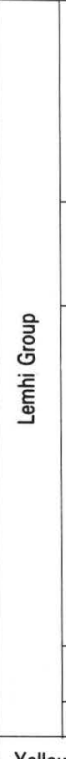 } & $\begin{array}{l}\text { Gunsight } \\
\text { Formation }\end{array}$ & 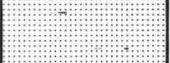 & 1800 & 16 \\
\hline & & $\begin{array}{l}\text { Apple Creek } \\
\text { Formation }\end{array}$ & $\div-4-4$ & 900 & 16 \\
\hline & & $\begin{array}{l}\text { Big Creek } \\
\text { Formation }\end{array}$ & & 3000 & 16 \\
\hline & & $\begin{array}{l}\text { West Fork } \\
\text { Formation }\end{array}$ & $\begin{array}{c}=\div \\
\square=\square\end{array}$ & 500 & 16 \\
\hline & & Inyo Creek Fm & & 300 & 16 \\
\hline & \multicolumn{2}{|c|}{ Yellowjacket Formation } & 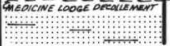 & $5000+$ & \\
\hline
\end{tabular}

EXPLANATION

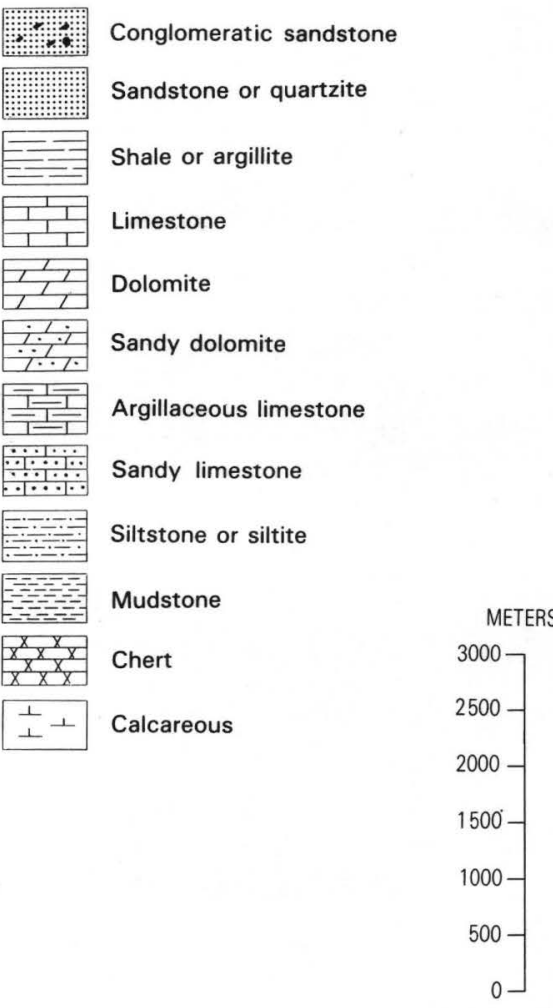

\section{REFERENCES}

1. Axelsen (1973)

2. Cressman and Swanson (1964)

3. Dennison (1968)

4. Embree, Hoggan, Williams, and Skipp (1975)

5. Hait (1965)

6. Hobbs (1980)

7. Huh (1967)

8. James and Oaks (1977)

9. Lucchitta (1966)

10. M'Gonigle (1965)

11. Mamet, Skipp, Sando, and Mapel (1971)

12. Mapel, Read, and Smith (1965)

13. Mapel and Shropshire (1973)

14. Ross (1961)

15. Ruppel (1968)

16. Ruppel (1975)

17. Ruppel (1978)

18. Ruppel and Lopez (1981)

19. Ruppel, Ross, and Schleicher (1975)

20. Ruppel, Watts, and Peterson (1970)

21. Sandberg (1975)

22. Scholten and Hait (1962)

23. Scholten, Keenmon, and Kupsch (1955)

24. Scholten and Ramspott (1968)

25. Shannon (1961)

26. Skipp and Hait (1977)

27. Skipp, Hoggan, Schleicher, and Douglas (1979)

FIGURE 11.-Generalized stratigraphic column in the Medicine Lodge thrust plate, southwest Montana and east-central Idaho. 


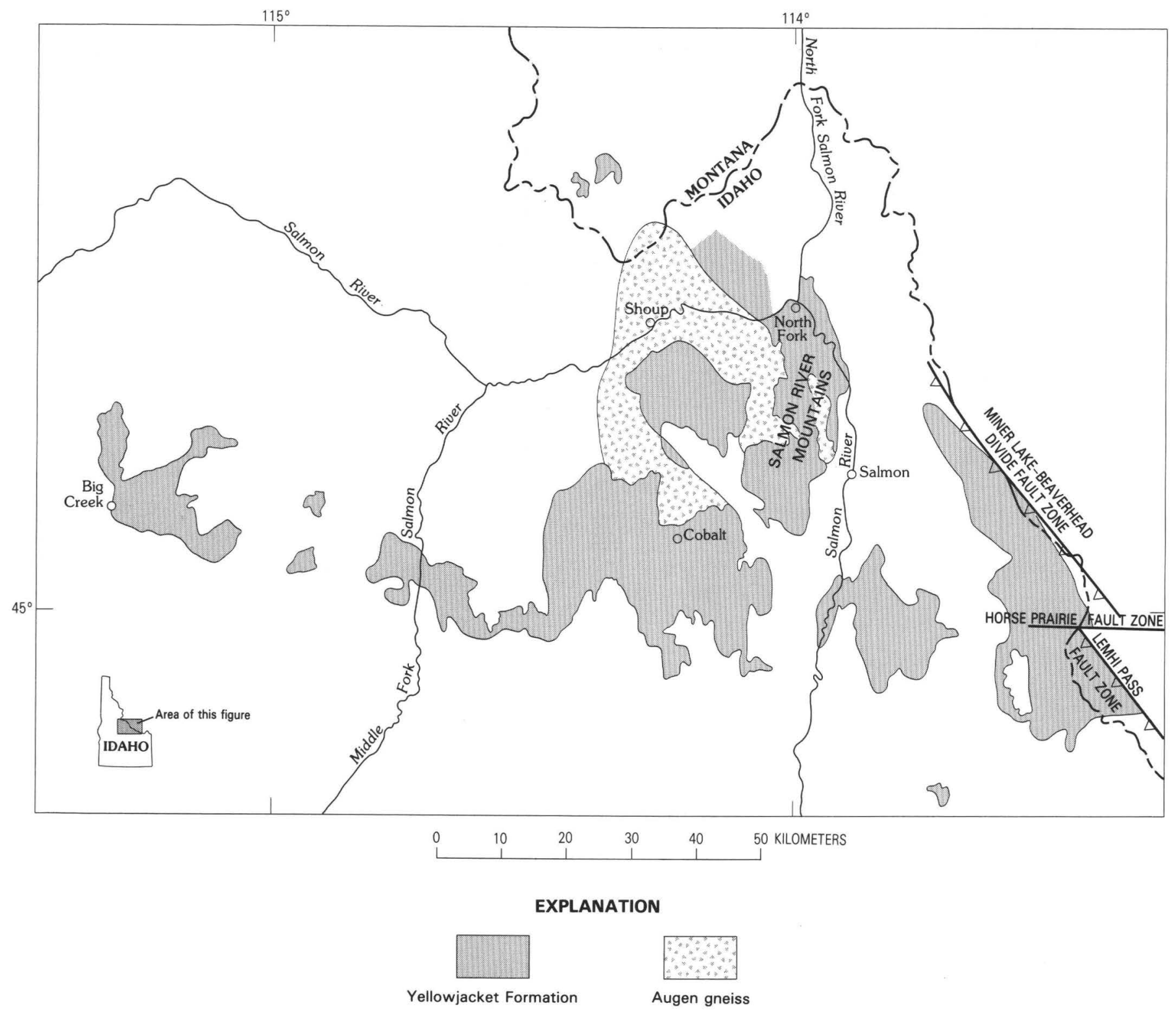

FIGURE 12.-Distribution of the Yellowjacket Formation in east-central Idaho. Heavy lines, faults; sawteeth on upthrust block.

(Lopez, 1981, p. 95). These relations suggest that the Yellowjacket Formation originally reached much farther to the east and that the original eastern facies of the formation have been destroyed.

The absence of Yellowjacket rocks east of the Beaverhead Mountains and the relations of the faults along its eastern disappearing edge suggest that the abrupt disappearance of the formation is a result of Precambrian faulting and subsequent erosion of the eastern facies. The Miner Lake-Beaverhead Divide fault zone includes several reverse faults, dipping $70^{\circ} \mathrm{W}$. or more, that break the Medicine Lodge thrust plate and displace it upward on the west side of the Beaverhead Moun- tains. The reverse faults are paralleled by wide zones of intense shearing in the Yellowjacket Formation (Mackenzie, 1949, p. 36), but the shearing does not extend into the overlying Medicine Lodge plate, which suggests that the shear zones were formed before regional thrusting, in an earlier episode of steep faulting. The absence of the Yellowjacket Formation east of the fault zone suggests that this early fault movement was down on the west, and that the Yellowjacket rocks on the eastern upthrown block were destroyed by erosion after faulting.

Regional stratigraphic relations suggest that early fault movement on the Miner Lake-Beaverhead Divide 
fault zone and on similar fault zones farther south in the Beaverhead Mountains took place in Proterozoic time, after the Yellowjacket was deposited, but well before the Missoula Group was deposited. The Grasshopper thrust plate, east of the Beaverhead Mountains, is composed mainly of rocks of the Missoula Group; the detritus in the fluvial-deltaic sediments of the Missoula Group suggests a source area of crystalline rocks (Winston, 1973a, b, 1978) and suggests, further, that any Yellowjacket originally east of the Miner LakeBeaverhead Divide fault zone was eroded away before deposition of Missoula Group rocks. In the frontal fold and thrust zone, Cambrian rocks were deposited on Archean crystalline basement rocks, and any original eastthinning edge of the Yellowjacket was eroded away before Cambrian deposition began.

Northwest-trending steep faults that cut crystalline basement rocks in southwest Montana have histories of Precambrian and later recurrent movement similar to the inferred history of the northwest-trending Miner Lake-Beaverhead Divide fault zone. Northwest-trending faults in and near the Tobacco Root Mountains have been intruded by diabase dikes that have yielded $\mathrm{Rb}-\mathrm{Sr}$ intrusive ages of about 1.1-1.4 billion years (Wooden and others, 1978, p. 474); these faults also have been the sites of repeated later reverse and normal movements in Late Cretaceous and Cenozoic time. The northwest-trending Miner Lake-Beaverhead Divide fault zone is intruded by strongly sheared and altered diabasic dikes similar to those farther east (Mackenzie, 1949, p. 25-30; Anderson, 1959, p. 32-33; Tucker, 1975, p. 115-123) and possibly also of Proterozoic age (Anderson, 1956, p. 37-38).

Granitic rocks, now partly augen gneiss, of Proterozoic age have been intruded into the Yellowjacket Formation farther west, in a pluton in the Salmon River Mountains (fig. 12). These rocks have yielded U-Pb ages on zircons of about 1.3-1.4 billion years (Evans and Zartman, 1981) and Rb-Sr whole-rock model dates of 1.3-1.5 billion years (Armstrong, 1975). The similarity of these radiogenic ages to those of the diabase dikes in the Tobacco Root Mountains and the structural similarities in the two areas suggest that Precambrian fault movement on the Miner Lake-Beaverhead Divide fault zone, and on the other faults that cut off the Yellowjacket Formation in the Beaverhead Mountains, probably took place at about the same time as movement on northwest-trending faults farther east, in a period of regional tectonism that preceded or accompanied regional emplacement of igneous rocks 1.3-1.4 billion years ago.

The regional structural relations in southwest Montana and east-central Idaho (Ruppel, 1982) and the structural and stratigraphic relations along the present east edge of the Yellowjacket Formation suggest that this period of regional tectonism produced major and lasting changes in this region. The Yellowjacket depositional basin was destroyed, and the present cratonic region of Archean crystalline rocks in southwest Montana was uplifted and exposed as the eastern facies of the Yellowjacket Formation was eroded. Later, Proterozoic Y rocks- the Lemhi Group, Swauger Formation, and Lawson Creek Formation-and the Paleozoic rocks of east-central Idaho were all deposited much farther west, in the Cordilleran miogeocline. And the steep basement faults that then, and now, bound and cut the cratonic region-the Miner Lake-Beaverhead Divide fault zone and its southern extensions, the Willow Creek and Camp Creek faults and other east-trending faults in southwest Montana, and other Precambrian faults-have moved recurrently in different directions at different times and continue now to control the structural fabric of southwest Montana and east-central Idaho.

Tear Faults and Salients.-The east edge of the Medicine Lodge thrust plate forms an almost straight line from the Snake River Plain to the edge of the Idaho batholith (fig. 10), with only a single, prominent eastward salient at Bloody Dick Peak. ${ }^{2}$

An explanation for the Bloody Dick salient remains elusive, because the geology of the area is only partly known (Coppinger, 1974), but a possible explanation is that the salient is bounded by tear faults similar to those interpreted as bounding the thrust salients in the frontal fold and thrust zone and the Grasshopper thrust plate. The southern part of the salient reaches nearly to the Horse Prairie fault zone (Scholten, 1981), an ancient fault zone interpreted to have been utilized as a tear fault during thrusting in the frontal zone and Grasshopper plate. (See p. 13, 15.) The southeast margin of the salient (fig. 10) is a northeast-trending fault, or fault zone, interpreted by Coppinger $(1974$, p. 183 185) to be a mid-Tertiary high-angle normal fault, down on the southeast. Some movement on the fault clearly is as interpreted by Coppinger, because the fault cuts Tertiary rocks, and it and parallel, related faults offset the pediment cut on the Tertiary rocks and drop the pediment down on the southeast. But the older rocks, beneath the Tertiary cover on the supposed downthrown block, are those of the Grasshopper thrust plate and are not like the rocks in the Bloody Dick salient of the Medicine Lodge plate-as they should be if the fault is simply a normal fault. The relations across

\footnotetext{
${ }^{2}$ Named, according to legend, after a pioneer settler called Bloody Dick, whose last name is lost in antiquity. Dick was not bloodied in some encounter with grizzly bears or road agents but, not very romantically, was an immigrant whose favorite expletive was "Bloody ***" and so he was known as Bloody Dick. He bacame immortal by giving his name to Bloody Dick Creek, where he settled, and to nearby Bloody Dick Peak.
} 
the fault suggest strike-slip movement, perhaps as a tear fault during thrusting, followed by recurrent, relatively minor dip-slip movement in Tertiary and Quaternary time.

The north side of the Bloody Dick salient is not well known, other than as a fault placing Lemhi Group rocks of the Medicine Lodge plate against Missoula Group rocks of the Grasshopper plate, and it has been mapped only in reconnaissance. The known relations do not suggest tear faulting, but the possibility remains that tearing could have taken place along one of several known or inferred steep faults north or northwest of the present margin of the salient (fig. 10), now separated from the salient as a result of erosion.

The Bloody Dick salient can be interpreted, too, as a mid-Tertiary slide plate derived from the upper part of the Beaverhead Mountains to the west and southwest as a result of block uplifting there. Regional evidence suggests that the present linear mountain ranges of the region, including the Beaverhead Mountains, formed as block uplifts in mid-Tertiary time and that the ranges were partly denuded by gravitational sliding of plates of rock into adjacent valleys on older thrust faults draped over the edges of the uplifted blocks (Beutner, 1972; Ruppel, 1982, p. 14). The block uplifting was accompanied by steep reverse faulting in places, including, in the Beaverhead Mountains, on the Miner LakeBeaverhead Divide fault zone, which can be traced into the Bloody Dick fault zone of Coppinger $(1974$, p. 167178) and southward to the Horse Prairie fault zone (fig. 10), where it is offset. It continues south of the Horse Prairie fault zone in the Lemhi Pass zone of northwesttrending faults (Staatz, 1972, 1973, 1979).

The crest of the Beaverhead Mountains, west and southwest of the Bloody Dick fault zone, is capped by only a thin remnant of the Medicine Lodge thrust plate (fig. 10). In most of the area immediately north and northeast of Lemhi Pass only remnants of the sheared and brecciated rocks of the Medicine Lodge décollement zone are preserved, dipping gently northeast above the Yellowjacket Formation. Staatz (1972, p. 31-32, 1979, p. A26-A27) interpreted these fragmented rocks to be old glacial deposits produced by a mountain icecap centered farther to the north and interpreted the rolling topography of this area to be subdued and dissected moraine. The sheared and brecciated rocks interpreted to be till can be traced into the Medicine Lodge décollement zone, however, beneath Lemhi Group quartzite and siltite in the Medicine Lodge thrust plate, a few kilometers farther north in the Beaverhead Mountains. The angular fragments in the supposed till are brecciated Lemhi Group rocks, dominantly of the Big Creek Formation, which also is the principal formation in the Bloody Dick salient, and the angular fragments are not deeply weathered as is characteristic of other old tills in the region (Ruppel, 1968, 1980). Reconnaissance geologic mapping in the Beaverheads north of the area discussed by Staatz $(1972,1979)$, in the area proposed as the center of old icecap glaciation, suggests that the only glaciers there were Pleistocene valley glaciers and that these joined into major ice streams only in their lower reaches. Thus, no clear evidence of old, presumably early Pleistocene, icecap glaciation is known in the Beaverhead Mountains, and we believe that the deposits described as old till by Staatz $(1972,1979)$ are, instead, the Medicine Lodge décollement zone and the lower part of the Medicine Lodge thrust plate. The gently rolling surface developed on these sheared and brecciated rocks is interpreted to be a result of surficial creep.

South of Lemhi Pass (fig. 10) the gently rolling crest of the Beaverhead Mountains is underlain by the Yellowjacket Formation (Staatz, 1972, 1979) as far south as the Peterson Creek thrust of Staatz (1973), the fault that forms the basal thrust zone of the Medicine Lodge plate in this area (Ruppel, 1978, p. 3). The Medicine Lodge plate has been removed, either by erosion or by denudation related to block uplift. The Bloody Dick salient could have slid east and northeast from the crest of the Beaverhead Mountains near Lemhi Pass, moving on the basal décollement that had been folded to its present northeastward dip north of Lemhi Pass as a result of mid-Tertiary block uplift (Ruppel, 1982, p. 11).

If such gravitational sliding took place, the sliding sheet might be expected to have overridden earlier Tertiary tuffaceous sediments, as well as the rocks of the Grasshopper thrust plate, but no firm evidence of overridden Tertiary rocks is known. In general, the distribution of Tertiary tuffaceous rocks in and near the Bloody Dick salient suggests that some of them could have become exposed by erosion from beneath the salient, but the available evidence on their structural relations is inconclusive. Tuffaceous conglomerate and finer grained sedimentary rocks are widely exposed in the central part of the salient, but these rocks are surrounded by upper Pleistocene glacial deposits, and their relation to rocks in the salient is not known. Tuffaceous conglomerates that crop out along the east side of Bloody Dick Creek are bounded by steep faults that place them against the Big Creek Formation of the salient; their relation to the rocks of the salient before faulting is uncertain.

In summary, the Bloody Dick salient could be either a tear-fault-bounded thrust-related salient, like those of the Grasshopper thrust plate and of the frontal zone, or a mid-Tertiary slide plate. Regional structural relations suggest that the slide plate interpretation is the most likely, but the available evidence is not conclusive. 
Farther south, a narrow segment of the Medicine Lodge plate along its southeast edge, just north of the Snake River Plain (pl. 1), also appears to be an early or mid-Tertiary slide plate (Ryder and Scholten, 1973, p. 792, 794; Garmezy and Scholten, 1981) derived from the main mass of the thrust plate immediately to the west.

\section{SUMMARY OF CONTRASTS IN AUTOCHTHONOUS AND ALLOCHTHONOUS ROCKS AND PALEOGEOGRAPHIC SPECULATIONS}

Unique stratigraphic sequences characterize each of the major thrust plates, the frontal fold and thrust zone, and the craton. Contrasts between these sequences suggest tectonic overlapping of sedimentary facies originally deposited in widely separated regions (fig. 13). The stratigraphic sequences of southwest Montana and east-central Idaho have long been recognized as including sediments deposited both in a shelf environment (those east of the Beaverhead Mountains), and in the Cordilleran miogeocline (in and west of the Beaverhead Mountains). But the cratonic region of central and western Montana was separated from the Cordilleran miogeocline by a large landmass, the Lemhi arch (Sloss, 1954; Ruppel, 1978, p. 12-14), which was flanked on the east by an intermittently flooded seaway, the Belt seaway of Harrison, Griggs, and Wells (1974, p. 3). The Lemhi arch persisted as a landmass from late Proterozoic through early Paleozoic time, influenced depositional patterns even after it was submerged in the Late Devonian, and probably was again a persistent landmass in the Mesozoic. The rocks now present in the thrust belt thus reflect depositional environments far more complex than a simple shelfmiogeocline transition and include rocks of miogeoclinal, seaway, and shelf origin, telescoped and scrambled in a complex of major thrust systems and minor imbricate thrusts.

The contrasts in Proterozoic sedimentary rocks are particularly striking. No Proterozoic sedimentary rocks are present in the frontal fold and thrust zone, or on the craton, but the Grasshopper thrust plate is composed almost entirely of rocks of the Missoula Group, in the Belt Supergroup. The rocks were deposited in an alluvial fan-delta complex (Winston, 1973a, 1978) in a southern arm of the Belt basin. The Proterozoic miogeoclinal sedimentary rocks of the Medicine Lodge plate were deposited in the Cordilleran miogeocline before uplift of the Lemhi arch. They do not have any clear lithologic correlation with the inferred time equivalent rocks of the Belt Supergroup, deposited in the
Belt basin in west-central Montana, or with the Missoula Group rocks of the Grasshopper plate.

Paleozoic rocks are widespread in southwest Montana, and on the craton a fairly complete section of Cambrian rocks overlies Archean crystalline rocks. In the frontal fold and thrust zone, Cambrian rocks are partly similar to the cratonic rocks, but the section is incomplete and much thinner (Moore, 1956, p. 15-16; Scholten and others, 1955, p. 352). In the Grasshopper plate, Cambrian rocks change both northward and westward across the plate. In the south part of the Grasshopper plate (fig. 9), all the formations of the cratonic sequence are present, but the upper part of the sequence thins westward and the Park Shale is present in the Jackson section only as shaly partings between the Meagher and Pilgrim Formations. The uppermost Cambrian rocks in the Jackson section resemble the Dry Creek and Sage Members of the Snowy Range Formation (Grant, 1965; Ruppel, 1972, p. A15A17). In the northern part of the Grasshopper plate, Cambrian rocks have been divided into the Silver Hill, Hasmark, and Red Lion Formations (Fraser and Waldrop, 1972; Calbeck, 1975, p. 26-35; Dutro and others, 1975). Most of the rocks are in the Hasmark Formation, which is as much as $245 \mathrm{~m}$ thick and nearly 20 times as thick as the equivalent Pilgrim Dolomite at Jackson. The Silver Hill and Red Lion Formations are only locally present and are comparatively thin even there, and the Flathead Sandstone is absent.

Cambrian rocks are present in the Medicine Lodge plate, farther west, only locally in part of the Wilbert Formation (Derstler and McCandless, 1981), and they reappear only in the Cash Creek Quartzite in central Idaho (Hobbs and others, 1968, p. J18-J19), probably in another major thrust plate west of the Medicine Lodge plate. The westward changes of Cambrian rocks from the craton across the thrust belt to the Medicine Lodge plate suggest that they originally thinned to the west, reflecting shoaling against the eastern shore of the Lemhi arch. The relation of Cambrian rocks in the Wilbert Formation in the Medicine Lodge plate suggests eastward thinning against the west flank of the Lemhi arch.

Ordovician and Silurian rocks are widely exposed in the southern and western parts of the Medicine Lodge plate, where the Ordovician forms the basal part of the Paleozoic sequence in most places, but they are not present farther east in the thrust belt or on the craton. Both Ordovician and Silurian sequences thin eastward against the western shore of the Lemhi arch and are absent on the eastern flank of the arch, indicating that the arch was dry and continuous with the exposed craton.

Devonian rocks on the craton include dark-colored 

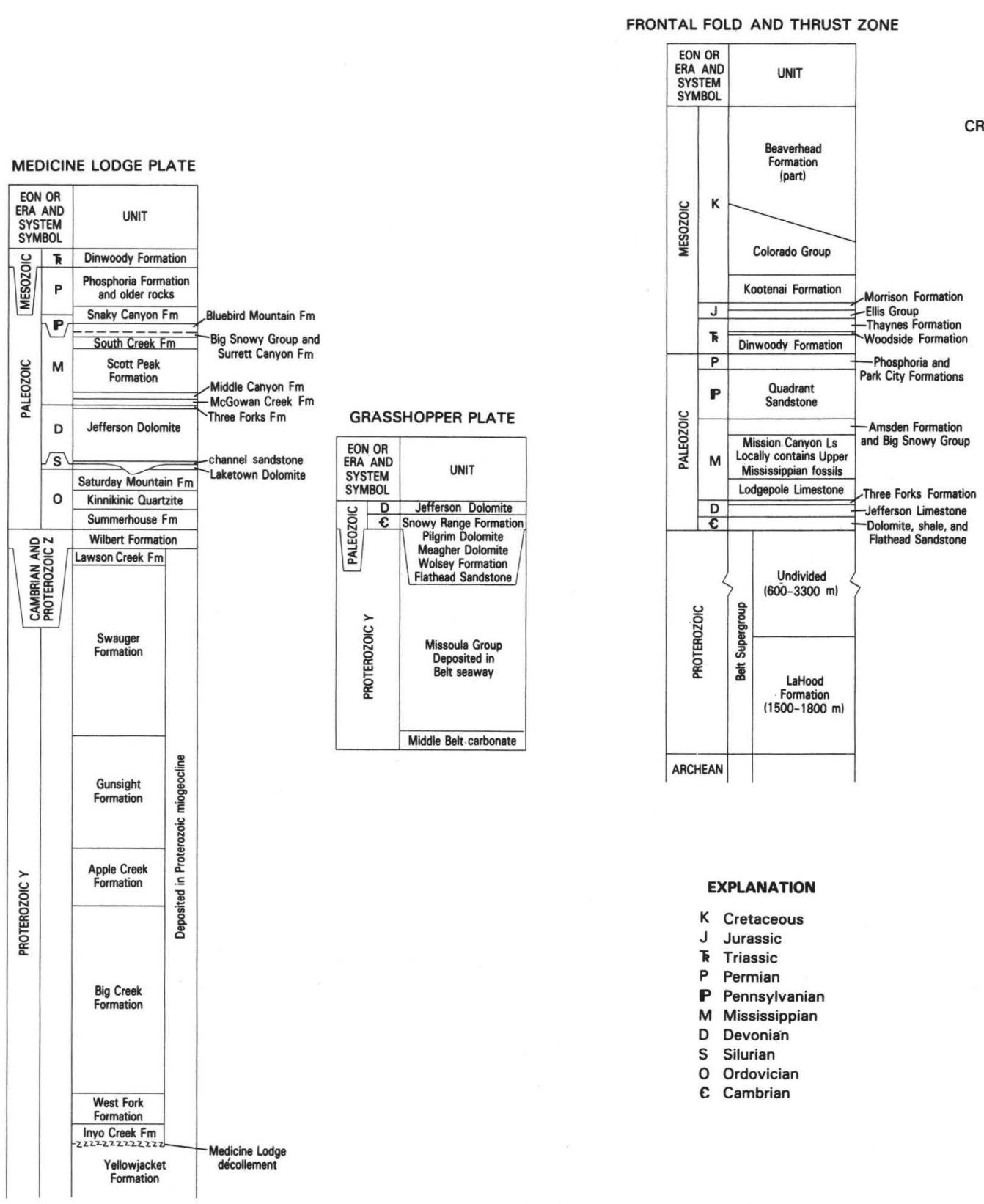

CRATON EAST OF THRUST BELT
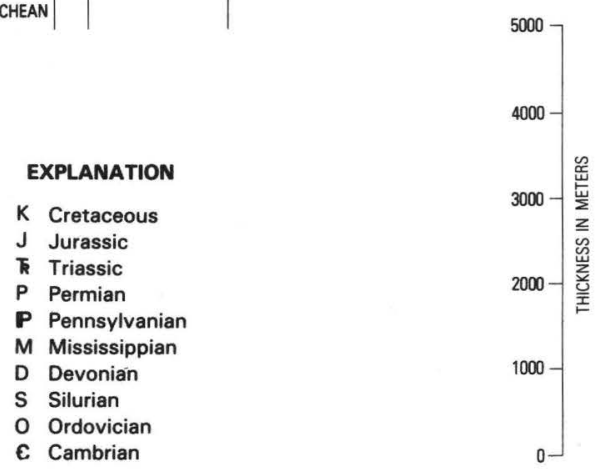

FIGURE 13.-Summary of autochthonous and allochthonous stratigraphic sequences, southwest Montana and east-central Idaho.

dolomite of the Jefferson Dolomite and thin-bedded shale, dolomite and limestone, and sandstone of the Three Forks Formation, all of Late Devonian age. The Devonian of the frontal fold and thrust zone includes a thick light-colored limestone at the top of the Jefferson, not present in the autochthonous sequence on the craton, and is thicker than farther east; the rocks are of Late Devonian age, like those on the craton. In the Grasshopper plate, the Jefferson is mainly dark gray dolomite and dolomitic limestone, but the Jefferson is preserved only in the Polaris area, where only part of the formation is present, so that its thickness is not known (D. R. Zimbelman, oral commun., 1979). In the Medicine Lodge plate, dark-colored dolomite and dolomitic limestone remain characteristic of the Jefferson, but the lower part of the formation is sandy, in places conglomeratic, and the formation thickens westward by addition of older Devonian rocks. Only Upper Devonian rocks are present in the Beaverhead Mountains, but in the Lemhi Range, to the west, the lower part of the thick carbonate sequence is of Middle Devonian age, above basal fresh- or brackish-water channel sandstones of Middle Devonian age (Denison, 1968). The Three Forks Formation also thickens westward in 
the Medicine Lodge plate but is lithologically fairly uniform.

The various sequences of Devonian rocks suggest that the Lemhi arch was finally submerged by Late Devonian time. Those in the Lemhi Range reflect marine transgression on the western shore of the arch after the Middle Devonian channel sands were deposited. The gradual lithologic changes and westward thickening of the Three Forks Formation suggest that these uppermost Devonian rocks were deposited in a widespread, shallow sea that reached from the miogeocline far onto the craton.

Contrasts in Mississippian and younger Paleozoic rocks in southwest Montana and east-central Idaho led Sloss and Moritz (1951, p. 2156-2160) to suggest that a zone of thrust faulting separated rocks from very different depositional provinces, reflecting major tectonic telescoping. Mississippian rocks change from the Madison Group, Big Snowy Group, and Amsden Formation on the craton to rocks called Madison, Big Snowy, and Amsden in the frontal zone of the thrust belt but which may include rocks (in the Madison) appreciably younger than typical Madison rocks. The rocks called Madison in the Tendoy Mountains apparently include Upper Mississippian rocks, near the top of the sequence, younger than typical Madison (Scholten and others, 1955, p. 363366). In the Argenta area, the carbonate sequence called Madison and Amsden in the frontal zone may include rocks that mostly are younger than typical Madison (Shenon, 1931, p. 48-49; Myers, 1952, p. 8). The rocks called Madison in the frontal fold and thrust zone, therefore, may be partly the time equivalents of the Middle Canyon and Scott Peak Formations, farther west, and younger than the autochthonous Madison. No Mississippian rocks are known in the Grasshopper plate. In the Medicine Lodge plate, the shale-carbonate miogeoclinal sequence is much thicker than farther east and consists of rocks that mainly are younger than autochthonous Madison rocks. The rocks suggest deposition of marine shales and carbonate rocks from the miogeocline, in central Idaho, to the craton in southwest Montana in Early Mississippian time, followed by progressive shrinking of the Mississippian sea and mainly miogeoclinal deposition in Late Mississippian time. The occurrence of gypsum in the lower part of the Big Snowy Group in the Tendoy Mountains (Sloss and Moritz, 1951, p. 2158) suggests that the region east of the Lemhi arch was one of evaporite deposition during part of Late Mississippian time.

Pennsylvanian rocks in the frontal zone of the thrust belt are nearly three times as thick as on the craton. The Amsden Formation is thicker than on the autochthon, as is the Quadrant Sandstone, which is quartzite and sandstone, without interbedded carbonate rocks that are present in autochthonous sections. In the Medicine Lodge plate, Pennsylvanian rocks are dominantly carbonate rocks and are very thick. Moreover, these rocks in large part are older (David A. Bostwick, written commun., 1968; Axelsen, 1973) than Pennsylvanian rocks elsewhere in the thrust belt in southwest Montana or on the craton. The changes suggest that transgressive sandstones spread from the miogeocline on the west flank of the Lemhi arch, across the arch, and that a deep trough formed east of the arch in later Pennsylvanian time. The basal sand was succeeded by carbonates in the miogeocline and, finally, by a regressive sandstone.

Permian rocks thicken and change lithofacies from the craton westward across the thrust belt. In the frontal zone, most Permian formations are appreciably thicker than on the craton, and some, like the Grandeur Member of the Park City Formation, more than double in thickness across the edge of the thrust belt. In addition, most formations become more detrital, or more calcareous, than on the craton. No Permian rocks are known in the Grasshopper plate. In the Medicine Lodge plate, Permian rocks seem to thicken more and to include more carbonate rock and less phosphate rock. The original depositional pattern probably was similar to that of Pennsylvanian rocks.

Triassic rocks were deposited in a northward-thinning wedge around a Triassic highland (Moritz, 1951) and are neither widespread nor uniformly represented on the craton. Triassic rocks in the frontal zone of the thrust belt are thicker than farther east and include the most complete Triassic sequence in southwest Montana; they thin northward within the frontal zone, and some formations disappear to the north. No Triassic rocks are known in the Grasshopper plate, and in the Medicine Lodge plate only the Dinwoody Formation is preserved, about $300 \mathrm{~m}$ thick, and is much sandier than elsewhere.

Jurassic rocks on the craton form a thin and incomplete sequence, mainly of the Morrison Formation, deposited in a northward-thinning fringe around a Jurassic highland in this region, a highland that persisted from Triassic time (Moritz, 1951). The sequence is more complete in the southern part of the frontal zone of the thrust belt, where marine Jurassic rocks of the Ellis Group are overlain by the nonmarine Morrison Formation, but farther north only the Morrison Formation is present. No Jurassic rocks are known in the Grasshopper or Medicine Lodge plates.

The contrasts in Triassic and Jurassic rocks suggest that Triassic marine rocks were originally deposited in a westward-thickening sequence well into east-central Idaho and that this sequence thinned northward against a highland. The highland persisted into the Jurassic, 
probably becoming larger and merging with Jurassic uplifts to the west.

The lowest Cretaceous rocks-those of the Lower Cretaceous Kootenai Formation-are much thicker in the frontal zone of the thrust belt than on the craton and are not known in either the Grasshopper or Medicine Lodge plates. Post-Kootenai marine and nonmarine rocks of late Early Cretaceous and Late Cretaceous age are present both on the craton and in the frontal zone of the thrust belt, but the rocks in the northern part of the frontal zone apparently are twice as thick as those to the south in the frontal zone or to the east on the craton. The autochthonous and allochthonous sequences both include marine rocks low in the sections that seem clearly to be part of the Colorado Group, overlain by mostly nonmarine, partly lacustrine, partly volcanic rocks that seem to be much like Upper Cretaceous rocks included in the Eagle Sandstone and younger formations in Montana farther east (McMannis, 1965, p. 1813-1821; Roberts, 1972). Fossils indicate that the rocks range in age from early Late Cretaceous in the autochthonous Ruby River section (Klepper, 1950, p. 68-70) to late Late Cretaceous (Judith River Formation of Campanian Age) in the allochthonous section at Argenta (Myers, 1952). The autochthonous Ruby River section inludes rocks below the fossiliferous zones that are lithologically like the Thermopolis and Mowry Shales and probably are of late Early Cretaceous (late Albian) age.

Later Cretaceous rocks probably were deposited mainly in increasingly restricted basins in southwest Montana, for Klepper (1950, p. 75-76) noted that rocks equivalent to and younger than the Mesaverde Formation (about middle Late Cretaceous) in southwest Montana contain locally derived pebble beds and grits with abundant angular fragments that indicate regional uplift. As a result of uplift and folding, the middle and uppermost Cretaceous rocks seem to have been deposited only in synclinal basins, as the adjacent anticlinal highlands were stripped of their cover. At the same time, however, deposition of conglomerates and sandstones of the Beaverhead Formation, interfingering with the Cretaceous rocks in the synclinal basins, suggests that thrust movement had begun farther west and that increasingly greater amounts of debris were derived from the west.

\section{BEA VERHEAD FORMATION}

The Beaverhead Formation was originally considered to be a synorogenic deposit, principally composed of coarse debris resulting from Late Cretaceous orogeny (Lowell and Klepper, 1953) - a sequence as much as $3,000 \mathrm{~m}$ thick of different lithofacies deposited at the leading edge of the thrust belt, essentially in its present position. Subsequent studies have refined the stratigraphy of the formation and have extended its age so that rocks included in the formation are now known, mainly on the basis of pollen assemblages, to range in age from late Early Cretaceous (late Albian) to latest Cretaceous (Campanian and Maestrichtian), probably Paleocene, and possibly early Eocene (Wilson, 1970; Ryder and Ames, 1970; Ryder and Scholten, 1973, p. 782-783). These rocks, therefore, are partly equivalent to the late Early Cretaceous marine sandstones and black shales and younger Cretaceous rocks of the autochthonous Ruby River section, and to allochthonous sandstones and shales in the frontal zone of the thrust belt, and it now seems clear that the Beaverhead Formation, as originally defined and subsequently refined, includes both allochthonous and autochthonous rocks.

The Beaverhead Formation in the frontal zone of the thrust belt is cut by imbricate thrusts and tectonically overlaps contemporaneous Cretaceous marine and nonmarine rocks of the Colorado Group and Montana Group on the craton. The original sedimentary relations of these rocks are not clear; however, some of the finer grained units of the Beaverhead, some of the other Cretaceous rocks in the frontal zone, including those called Lower Cretaceous Aspen Shale in the Tendoy Mountains (Scholten and others, 1955, p. 367-368), and some of the autochthonous sandstones are probably eastern distal facies of coarser grained conglomeratic units deposited farther west, now brought together as a result of thrust faulting. In this view, conglomerates originally were deposited in alluvial fans at the toe of the advancing Medicine Lodge plate, some unknown distance to the west, and the finer grained units were deposited farther east at the distal ends of the fans, contributing to the thick sandstones in the Cretaceous Colorado and Montana Groups. The coarse deposits perhaps were mostly trapped in an isostatically induced depression, or peripheral moat, migrating northeastward in front of the advancing thrust plates (Price, 1973, p. 498-501), and the sands were distributed farther east, partly into local synclinal basins between block uplifts on the craton. The synchronous occurrence of thrusting to the west, deposition of Beaverhead conglomerates in a migrating moat, and uplift of blocks on the craton (Klepper, 1950, p. 75-76; Tysdal, 1970, p. 105-119; Swanson, 1970 , p. 718; Ruppel, 1982 , p. 15) suggests that the Late Cretaceous uplifts in southwest Montana reflect an isostatically induced foreland bulge. This bulge is expressed mainly in vertical movements on preexisting discrete basement blocks over which the veneer of sedimentary rocks was draped into domal uplifts and synclinal basins.

As the Medicine Lodge plate advanced, new fans 
formed and older ones were either recycled into progressively finer grained deposits, were caught up in imbricate thrusts at the toe of the plate, or were overridden or destroyed. With development of the frontal fold and thrust zone, in the final stages of thrusting, the existing fan deposits at the toe of the Medicine Lodge plate were cut and carried eastward by imbricate thrusts and brought to their present position as these thrusts overrode their own debris fans, other finer grained deposits derived from the Medicine Lodge plate, and locally derived autochthonous deposits.

The stratigraphic and structural relations of the Beaverhead Formation and of Colorado Group and Montana Group rocks thus suggest that they originally interfingered in east-central Idaho as early as in late Early Cretaceous (late Albian) time. Fingers of Beaverhead sand probably form part of the thick accumulation of Upper Cretaceous sandstone in southwest Montana. Conglomerate units in the frontal zone of the thrust belt probably reflect deposition at various times, and in various places, in a migrating peripheral moat in front of the advancing Medicine Lodge plate, and now are shuffled together by imbricate thrust faults.

Earlier studies of coarse detritus in the Beaverhead Formation have provided many data on source directions and probable source regions but have not considered the possibility of major tectonic transport of the Beaverhead Formation (Scholten, 1968, p. 117; Wilson, 1970, Ryder and Ames, 1970, p. 1167-1170; Ryder and Scholten, 1973, p. 783-790). In general, all of these studies have recognized that Proterozoic sedimentary rocks of east-central Idaho must be the source of most of the quartzite and siltite boulders and cobbles in the Beaverhead Formation. Because these Proterozoic rocks now crop out far to the west of the Beaverhead Formation, the coarse fragments were necessarily assumed to have been carried $80 \mathrm{~km}$ or more eastward in high-gradient streams, seemingly without significant reductions in clast diameters. Ryder and Scholten (1973, p. 788-789) suggested that the detritus was constantly recycled from one fan to another and that it moved eastward from a series of eastward-migrating uplifts which maintained the required steep stream gradients.

Transportation of Beaverhead conglomerates by thrusting makes long distance transport of bouldery detritus by streams unnecessary, for it requires that the boulder gravels be deposited only once, in alluvial fans at the toe of the Medicine Lodge plate, and that the rest of the journey of the gravels to southwest Montana be completed on thrust faults. If bouldery deposits were recycled by streams, the boulders were worn down, ultimately to provide the sand of finer grained deposits or in the matrix of conglomerates, and new coarse de- tritus was constantly provided by the advancing Medicine Lodge plate.

Even greater transport-160 to $320 \mathrm{~km}$-was suggested by Lindsey (1972, p. B56-B65) to account for the boulders and cobbles of Proterozoic quartzites, thought to be from east-central Idaho, in the western facies of the Upper Cretaceous and Paleocene Pinyon Conglomerate of northwestern Wyoming. The mechanism proposed by Lindsey (1972, p. B62) also was a succession of eastward-migrating uplifts accompanied by successive reworking of conglomerate deposits. Antweiler and Love $(1967$, p. 2) had earlier proposed that the Pinyon gravels were derived from erosion of bedrock in a now-buried uplift southwest of Yellowstone Park-the Targhee uplift (Love, 1968). Lindsey (1972, p. B64) discussed the hypothetical Targhee uplift and concluded that available geophysical and geologic evidence did not confirm it. He also considered (Lindsey, 1972, p. B64) the possibility of far-traveled thrust plates as a source of gravels but concluded that the then-known major thrust in southwest Montanathe Medicine Lodge thrust fault (Scholten and others, 1955 , p. 382-383) - was too far from the conglomerates near Jackson Hole, Wyo., to provide a reasonable source. Extension of the leading edge of the thrust belt into the Centennial Range in southwest Montana brings the southwest Montana thrust belt nearly into the region of the Targhee uplift (fig. 14), however, and suggests that the Pinyon Conglomerate was indeed derived locally, but from the leading edge of the thrust belt, and that the source was thrust-transported synorogenic alluvial-fan conglomerate like that in the Beaverhead Formation.

\section{AGES OF THRUST FAULTING}

The ages of movements in the thrust belt of southwest Montana and east-central Idaho are only partly known. A minimum age is suggested by $10 \mathrm{~K}$-Ar dates of $62-76 \mathrm{~m} . \mathrm{y}$. on the complex plutons that form the Pioneer batholith, which intrudes the Grasshopper plate (Zen and others, 1975; Zen, 1977a, p. 780). The McCartney Mountain stock, which intrudes the frontal fold-and-thrust zone east of the Pioneer batholith, has yielded a preliminary K-Ar date of $70 \pm 1.5$ m.y. (Brumbaugh, 1973, p. 48).

Ryder and Scholten (1973, p. 783) suggested that deposition of the synorogenic Beaverhead Formation began in late Early Cretaceous (Albian) time, reflecting the beginning of major regional uplift and tectonism to the west, in the region of the Idaho batholith. The Beaverhead Formation is intensely folded and cut by imbricate thrusts (Lowell, 1965), and so it must reflect tectonism extending from the initial uplifts in central 


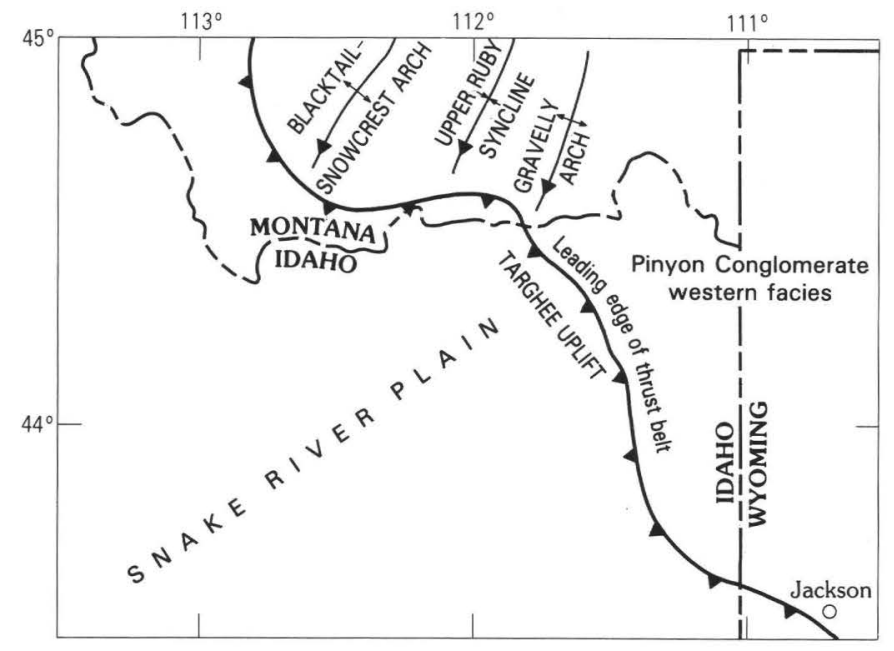

FIGURE 14.-Relation of the thrust belt to the Targhee uplift.

Idaho to the arrival of the major thrust plates; some units include detritus eroded from those plates after their arrival.

The combined stratigraphic and radiometric evidence suggests that thrust fault movement began no later than late Early Cretaceous (Albian) time, perhaps 100 m.y. ago, and was completed by about 70-75 m.y. ago. The Medicine Lodge plate is inferred to be older than both the Grasshopper plate and the frontal fold and thrust zone, but how much older is not known.

\section{RELATION OF THE THRUST BELT IN SOUTHWEST MONTANA TO THE SIXTEENMILE THRUST ZONE AND TO OTHER THRUST PLATES IN WEST-CENTRAL MONTANA}

The thrust belt in southwest Montana generally has been assumed to merge, somehow, with the Sixteenmile thrust zone and the disturbed belt of west-central Montana, perhaps through the east-trending Willow Creek fault zone at the north end of the Tobacco Root Mountains (pl. 1). The eastward limit of thrusting has thus been depicted as a curving line made irregular by eastward salients and westward reentrants, and the irregularities have provoked discussion as to their causes and consequences (Beutner, 1977; Brumbaugh and Hendrix, 1974; Schmidt and others, 1977). But linking the thrust belt in southwest Montana and the disturbed belt in west-central Montana in this manner ignores some fundamental differences in the two regions and fails to consider Robinson's conclusion (1963, p. 108) that the thrusts from farther north, the Sixteenmile thrust zone, end at the Jefferson Canyon fault, one of the east-trending faults in the Willow Creek fault zone at the north end of the Tobacco Root Mountains. The differences in the two regions support Robinson's conclusion, and include

1. Differences in rock sequences.-The rocks of the Sixteenmile thrust zone and farther north in the Elkhorn Mountains are essentially the same as the autochthonous rocks on the craton to the south, except for the presence of Belt Supergroup rocks. They are unlike any of the allochthonous rocks in the thrust belt in southwest Montana. The addition of Belt rocks reflects the crossing of the Willow Creek fault zone between the Precambrian craton and the Belt basin (McMannis, 1963, p. 433-434; Harrison and others, 1974, p. 2-3).

2. Differences in structural style.-Rocks in the Sixteenmile thrust zone are broadly folded and are cut by widely spaced imbricate thrusts of relatively small displacement (Robinson, 1963, p. 107108). In contrast, many of the rocks in the thrust belt in southwest Montana are tightly folded, in places isoclinally, and are cut by multiple, closely spaced imbricate thrusts.

3. Differences in age.-Thrusting in the Sixteenmile thrust zone began no earlier than middle Campanian time, about 76 m.y. ago (Robinson and others, 1968, p. 571). Farther east, the thrusting ended by late Paleocene time (Hoffman and others, 1976, p. 20). Plates in the thrust belt in southwest Montana and east-central Idaho were thus in their present positions when thrusting began in the Sixteenmile thrust zone.

The leading edge of the thrust belt in southwest Montana, therefore, cannot be tied to the Sixteenmile thrust zone. The edge of the southwest Montana thrust belt is fairly well defined as far north as the Highland Mountains; north of there, only rocks of the Boulder batholith, intruded after thrusting, are exposed for many kilometers, and the northward projection of the frontal fold and thrust zone remains uncertain.

The Grasshopper thrust system is probably equivalent to part of the Sapphire thrust system, west of the Boulder batholith, because the two plates include some similar rocks and are structurally similar (Wallace and others, 1979; Ruppel and others, 1981, p. 157).

The northern extension of the Medicine Lodge thrust system may be represented in the flat faults, mapped by Berg (1977, p. 27), in southernmost Ravalli County, Mont., northwest of the Beaverhead Mountains, for the rocks of the thrust plate there (Berg, 1977, p. 3-13) are like those in the Medicine Lodge plate farther south. The Medicine Lodge plate seems to continue its persistent northwest trend to the border of the Idaho batholith. Thrust plates of comparable dimension, composed of such far traveled and different rocks, are not present farther north and northeast in the region of the Sapphire thrust system (Hyndman and others, 1975; Wallace and others, 1979). Because the size, makeup, and trend of the Medicine Lodge plate do not seem to be changing significantly as it approaches the batholith, the plate (or comparable other thrust plates) probably originally extended farther northwest and has been destroyed by intrusion of the batholith or by later uplift and erosion. 
The extension of the Medicine Lodge thrust plate as far northwest as the Idaho batholith and the likelihood that it or comparable plates might originally have reached even farther northwest suggest that major thrust plates rode onto the western part of the Belt basin (Harrison, 1972) shortly before or at about the same time that thrust faulting began along the south margin of the Belt basin farther east. The apparently close relation in time would seem to suggest a genetic relation as well-that thrust deformation in at least the southernmost part of the Belt basin is a response to overriding of the western part of the Belt basin by massive thrust plates, like the Medicine Lodge plate, derived from even farther west in the Cordilleran miogeocline.

\section{SUMMARY AND INTERPRETATION OF STRUCTURAL RELATIONS IN THE THRUST BELT IN SOUTHWEST MONTANA AND EAST-GENTRAL IDAHO}

The thrust belt in southwest Montana and eastcentral Idaho includes two major thrust plates, the Medicine Lodge and Grasshopper plates, and an easternmost frontal zone of tight folds and imbricate thrust faults. The frontal zone forms the leading part of the thrust belt in southwest Montana and consists of an internally more or less consistent sequence of Paleozoic and Mesozoic sedimentary rocks and imbricate slices of Archean crystalline rocks. The lower and middle Paleozoic rocks in the frontal zone thin westward, reflecting deposition against the east flank of the Lemhi arch, and now are telescoped eastward over the more complete sequence of Paleozoic rocks on the craton. Younger rocks reflect marine and nonmarine deposition east of and across the arch and suggest that at times a trough east of the arch retained thicker accumulations of sediment. The arch continued to influence deposition at least through Paleozoic time (Ruppel, 1978, p. 14).

The Grasshopper plate overlaps and is structurally partly above the frontal zone, but the south margin of the plate is the steep, east-trending Horse Prairie fault zone, along which the thrust plate moved laterally against the frontal thrust zone. The Grasshopper plate is made up of a thick sequence of Proterozoic sedimentary rocks deposited in the Belt seaway, overlain in a few places by lower Paleozoic rocks that are different from those elsewhere in southwest Montana.

The Medicine Lodge plate is structurally above the Grasshopper plate and the frontal zone and consists of very different rocks. These rocks include a thick sequence of miogeoclinal Proterozoic and Paleozoic sedimentary rocks. Mesozoic rocks are known in only two places and include only Triassic rocks. The rocks of the Medicine Lodge plate differ more from the autochthonous rocks east of the thrust belt than do the rocks of either the Grasshopper plate or the frontal zone, suggesting that the Medicine Lodge plate has been transported tectonically much farther, perhaps as much as $160 \mathrm{~km}$ (Ruppel, 1975, p. 16, 1978, p. 3) from the miogeoclinal region in central Idaho. A few thrust slices of granitic rocks in the eastern part of the plate have been interpreted to be either lower Paleozoic intrusive rocks or Archean Dillon Granite Gneiss (Ruppel, 1978, p. 18). Radiometric age determinations suggest that the granitic rocks are of Ordovician-Silurian age (Ruppel, 1968; Scholten and Ramspott, 1968, p. 21; Evans and Zartman, 1981), and part of a pluton lifted off the underlying autochthon a short distance farther west, but some Archean rocks with ages mixed by tectonism and plutonism could be included, as well.

Throughout the thrust belt, the rocks are folded and cut by imbricate thrusts and clearly show the effects of deformation far more intense than that in the simple drape folds and steep faults on the craton. The rocks in the Medicine Lodge plate, however, seem to be the most complexly deformed of all, for these rocks are almost isoclinally folded in many places in the Lemhi Range and Beaverhead Mountains and are broken by scores of closely spaced, interlacing imbricate thrust faults.

The extreme folding and faulting in the Medicine Lodge plate seem to require some extreme cause and suggest that the deformation is a result of the plate crumpling against the craton. The abrupt appearance of imbricate thrust slices of granitic rocks in the southeastern part of the Medicine Lodge plate, on the west flank of the Beaverhead Mountains, suggests that they were lifted off the underlying autochthon some unknown distance farther west and carried up into the thrust plate on imbricate thrusts. The presence of crystalline basement at shallow depth beneath the Beaverhead Mountains is suggested by the wide distribution of crystalline rocks in reverse-faulted blocks east of the Beaverhead Mountains (Scholten and others, 1955 , p. 383-385) and by their absence to the west and north, where the Yellowjacket Formation is everywhere beneath the Medicine Lodge décollement (Ruppel, 1978, p. 8). The relations in this southeastern part of the plate suggest that this was a region where the Medicine Lodge basal décollement passed out of the Yellowjacket Formation across concealed northwesttrending Proterozoic faults, related to the Miner LakeBeaverhead Divide fault zone, and intersected crystalline rocks and broadly folded Paleozoic and Mesozoic sedimentary rocks of the cratonic shelf. The Medicine Lodge plate crumpled against the craton into the tight 
overturned folds and imbricate thrusts that now characterize much of the central Lemhi Range and Beaverhead Mountains. The relations suggest, too, that as the toe of the Medicine Lodge plate crumpled against the craton, the rocks of cratonic shelf, beneath and in front of the plate, were tightly folded and broken by imbricate thrust faults in the frontal fold and thrust zone.

Farther north, the leading part of the Medicine Lodge plate is structurally above the Grasshopper plate (fig. 15) and does not include imbricate thrust slices of crystalline rocks that might suggest cratonic basement beneath it. The absence of crystalline rocks in the thrust plate, the presence of only Yellowjacket Formation beneath the Medicine Lodge plate to the west, and the thick sequence of Belt seaway Missoula Group rocks in the Grasshopper plate to the east suggest that this part of the Medicine Lodge plate overrode the westernmost part of the sequence of Proterozoic and Paleozoic sedimentary rocks of the Belt seaway region. The heel of the Grasshopper plate must be west of the Big Hole Basin in southwest Montana. There, the Medicine Lodge décollement intersected the Miner Lake-Beaverhead Divide fault zone and passed out of the Yellowjacket Formation, and the Grasshopper décollement formed beneath the leading edge of the Medicine Lodge plate in the different Proterozoic rocks of the Belt seaway. Eastward movement continued on the Grasshopper thrust plate until it, like the southern part of the Medicine Lake plate, ran against the cratonic crystalline uplifts and stopped. At its south edge, the Grasshopper décollement merged as a tear thrust with the Horse Prairie fault, which is also the fault-controlled south end of Belt rocks.

The thrust plates of southwest Montana and east-central Idaho thus carry miogeoclinal rocks eastward into tectonic contact with rocks deposited in the Belt seaway and with a still different sequence deposited on the craton and carry Belt seaway rocks eastward onto the cratonic sequence. Thrusting seems likely to have advanced by successive development of new plates beneath older ones. Thrusting stopped when the last plates overrode crystalline cratonic rocks in which no new décollement could be formed, and thrust faulting died out in the imbricate thrusts and tight folds of the frontal thrust zone. The Medicine Lodge plate probably is older than either the Grasshopper plate or the frontal zone of the thrust belt, for it includes rocks from much more distant regions to the west and so must reflect long continued movement. The smaller Grasshopper thrust plate and the complexly folded and faulted rocks that form the leading part of the thrust belt in southwest Montana reflect the different assemblages of rocks overridden by the major Medicine Lodge plate thrust and the new décollement zones and imbricate thrust faults that advanced the thrust belt in ever-decreasing amounts until it stopped against crystalline rocks on the craton.

The reentrants and salients along the leading edge of the thrust belt (Brumbaugh, 1973; Brumbaugh and Hendrix, 1974; Schmidt and others, 1977; Beutner, 1977) and along the edge of the Grasshopper thrust plate were controlled by faults of Precambrian ancestry that have moved recurrently in different directions at different times since the Precambrian. The salients are bounded by these both ancient and youthful steep faults, which were utilized as tear faults during thrusting. The faults appear to have controlled the edges of small depositional basins indenting the cratonic margin both before and during thrusting and, thus, to have controlled the accumulation of locally somewhat different, perhaps thicker, accumulations of sedimentary rocks. The salients partly reflect thrusting in such basins and tear faulting at the fault-controlled basin margins, but mainly they reflect eastward-directed lateral movement on ancient faults reactivated as tear faults during thrusting. The relatively small Blacktail, McCartney, and Highland Mountain salients extend eastward onto the craton, along east-trending and northwest-trending faults interpreted as tear faults, and the eastward bulge of the Grasshopper plate in the Pioneer Mountains is bounded by similar faults.

The east-trending Willow Creek fault zone has long been recognized as a tear fault related to thrusting (Robinson, 1963, p. 108; Schmidt and others, 1977), and along it the Cordilleran fold and thrust belt stepped far eastward in the rocks of the Belt basin, past the cratonic region of southwest Montana. The Centennial fault flanks the south edge of the cratonic region and appears to be similar to the Willow Creek fault zone; the Cordilleran fold and thrust belt steps eastward along it, past the cratonic margin, to join the Wyoming thrust belt beneath the Snake River Plain.

\section{MINERAL RESOURCES IN THE THRUST BELT}

The emplacement of intrusive igneous rocks and associated mineral deposits west of the leading edge of the thrust belt in southwest Montana and east-central Idaho appears largely to have been controlled by major thrust zones. The relations of intrusive rocks and associated mineral deposits in east-central Idaho to the Medicine Lodge thrust plate have been discussed in earlier reports (Ruppel, 1978, p. 18-20, 1982, p. 19). The mineral deposits in mining districts in east-central Idaho commonly are in the basal part of the Medicine Lodge thrust plate, around necklike stocks of granitic 

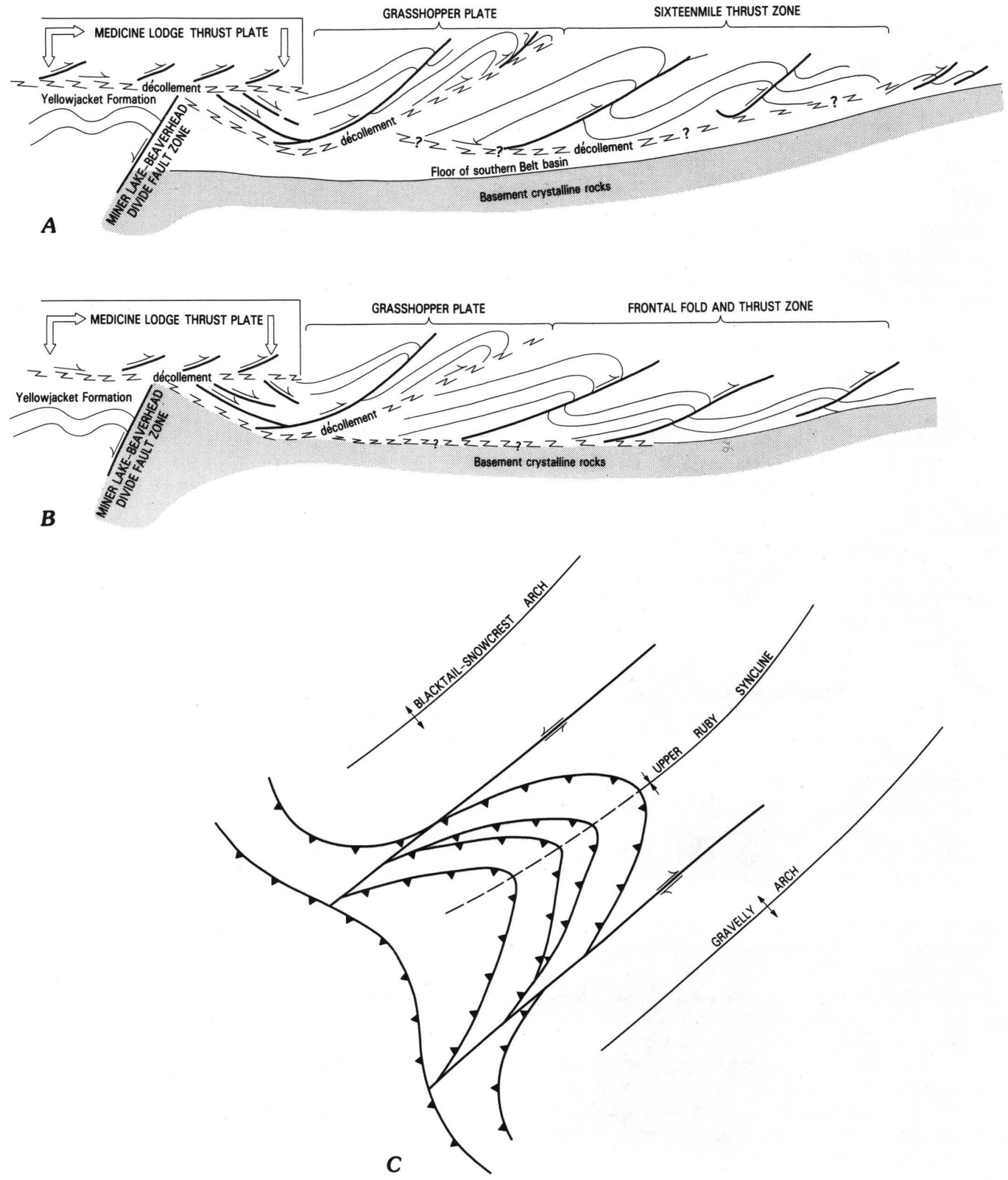

Figure 15.-Thrusts in structural and sedimentary basins overridden by thrust plates. $A$, Inferred relations of thrust plates near the south edge of the Belt basin; $B$, Inferred relations of thrust plates in southwest Montana; $C$, Thrust salients in structural and depositional basins along the leading edge of the thrust belt in southwest Montana. Arrows indicate relative fault movement; sawteeth on overthrust block. Syncline dashed where inferred. Line of décollement queried where relation uncertain. 
rocks. The stocks were intruded along deeper steep faults to the base of the thrust plate and, there, spread laterally as sheets in imbricate thrusts in the thrust plate, rather than rising higher in the thrust plate (Ruppel, 1978, p. 18-21, 1982, p. 19). Mineral deposits that have yielded substantial amounts of ore are clustered around the stocks, which were the sites of repeated intrusive pulses; mineral deposits associated with the sheets are small, and few of them have yielded much ore.

The relations of intrusive rocks and associated mineral deposits in the Pioneer Mountains mining area of southwest Montana (Geach, 1972) to the Grasshopper thrust plate are similar in many ways to those in the Medicine Lodge plate. Granitic rocks are much more widely exposed in the region of the Grasshopper thrust plate in southwest Montana than in east-central Idaho, and the major intrusive body of the region-the Pioneer batholith in the eastern part of the Pioneer Mountainswas intruded into Proterozoic rocks well above the basal zone of the Grasshopper plate (Karlstrom, 1948, p. 30-37; Myers, 1952; Zen and others, 1975; Snee, 1978). In the western part of the Pioneer Mountains, the granitic rocks mostly are in flat-topped intrusives that only locally crosscut the Grasshopper thrust plate. The granitic rocks are cut by northwest- and northeasttrending faults and fracture zones that control much of the present drainage and are parallel to faults and fracture zones of Precambrian ancestry elsewhere in southwest Montana. The flat roof and the duplication of older fracture patterns in the granitic intrusive rocks of the west Pioneer Mountains suggest that these rocks were, at least partly, intruded as thick sheets into the Grasshopper thrust zone, that these rocks are floored by older rocks beneath the thrust zone, and that these rocks are roofed by the Grasshopper thrust plate.

Most of the known major mineral deposits in the Pioneer Mountains mining area are in Paleozoic sedimentary rocks just below the basal zone of the Grasshopper thrust plate, and few mineral deposits of economic significance are known to occur above the thrust zone in the rocks of the Grasshopper plate. Representative major mining districts of the region include the following examples (pl. 1; for general descriptions, see Geach, 1972; Shenon, 1931; Karlstrom, 1948; Berger and others, 1979): The Bannack district, gold-silvercopper replacement deposits in Mississippian limestone, around the Bannack granodiorite stock; the Argenta district, silver-lead-gold replacement deposits in Mississippian and Devonian carbonate rocks, and narrow veins in overlying Proterozoic quartzite and argillite, near a quartz monzonite stock; the Hecla district, silver-lead replacement deposits in Cambrian and Devonian carbonate rocks, near the margin of the Pioneer batholith; the Quartz Hill district (Taylor, 1942), silver fissure veins and replacement deposits in Cambrian and Devonian carbonate rocks, southwest of the Mount Fleecer stock; the Calvert Hill mine area (Wisdom district), tungsten (scheelite) skarn deposits in upper Paleozoic and Mesozoic carbonate and clastic rocks, exposed in an erosional window through the Grasshopper plate; and the Polaris mine and nearby Baldy Mountain district, tungsten (scheelite) skarn (Baldy Mountain) and silver-lead-gold quartz veins, mainly in Mississippian limestone that probably is exposed in a window through the Grasshopper plate as a result of faulting and erosion. Geology of the area, however, is not well known.

The rocks favorable for deposition of metallic minerals are mostly below the Grasshopper plate, in contrast to those in the Medicine Lodge plate, which are in the basal part of the plate. In both plates, however, major thrust zones seem likely to have been primary structural controls on the emplacement of intrusive igneous rocks and associated deposits of metallic minerals. In east-central Idaho, intrusive magmas spread laterally as sheets in imbricate thrusts in the lower part of the Medicine Lodge plate, and the principal associated mineral deposits are in favorable host rocks in the lower part of the thrust plate around necklike stocks that feed the sheets. In the Pioneer Mountains mining area, in southwest Montana, intrusive magmas of batholithic dimensions cut the Grasshopper thrust plate in the eastern part of the area, but in the west Pioneer Mountains, the magma appears to have spread laterally in the basal thrust zone of the Grasshopper plate. The most favorable host rocks for mineralization in the Pioneer Mountains are the calcareous Paleozoic and Mesozoic sedimentary rocks beneath the Grasshopper plate, and the principal mineral deposits are in these rocks, rather than in the siliceous rocks of the thrust plate. The relations of replacement ore bodies in the Quartz Hill mining district, described by Taylor (1942), suggest that mineralizing solutions there and perhaps elsewhere in the Pioneer Mountains mining area were held beneath the Grasshopper plate by relatively impermeable gouge in the basal thrust zone. The ore shoots and bedded replacements at Quartz Hill are in Paleozoic limestone beneath Proterozoic quartzite of the Grasshopper plate; they do not penetrate the "shaly limestone" that is above the limestone host rock and beneath the thrust plate and that probably is part of the sheared thrust zone at the base of the Grasshopper plate.

Undiscovered mineral deposits in the thrust belt would seem most likely to be found near the basal zones of the Medicine Lodge and Grasshopper thrust plates, particularly in areas where older, steeply dipping faults or fracture zones could have channeled intrusive magmas and associated mineralizing solutions into host 
rocks suitable for ore deposition adjacent to the basal thrust zones (Ruppel, 1982, p. 19-21). The abundance of ore deposits around the edge of the Grasshopper plate (pl. 1) and in windows through the plate, and the probable presence of Paleozoic and Mesozoic rocks beneath much of the plate suggest that mineral deposits could be concealed beneath the Proterozoic rocks exposed in the central and perhaps western parts of the Pioneer Mountains and might be found by geochemical and geophysical prospecting.

The relation, if any, of the mineral deposits in the Highland Mountains (Sahinen, 1950) to major thrust plates is unknown. The edge of the thrust belt extends across the crest of the range east of Table Mountain, which suggests that some of the widespread mineral deposits in the western part of the Highlands, in and around the Moosetown district, could have been emplaced beneath thrust plates that have since been removed by erosion.

Not many metallic mineral deposits are known to occur in the frontal fold and thrust zone of the thrust belt south of the Grasshopper plate, and most of this region does not appear to offer much hope for new discoveries of hydrothermal ore deposits. Most of the prospects in the region, in the Monument and Medicine Lodge-Cabin Creek districts, explore small deposits of asbestos, graphite, thorium, copper, or rare earth minerals, in crystalline basement rocks, and very few of these have any record of production (Geach, 1972, p. 31-33, 164-168). The principal known exception is at the Sweeney (Bonanza II) mine in the Medicine Lodge district (Geach, 1972, p. 165-168), which explores a small replacement deposit of silver, lead, and zinc minerals in Mississippian limestone adjacent to Archean crystalline basement rocks along the Cabin Creek reverse fault of Scholten, Keenmon, and Kupsch (1955, pl. 1, p. 399). The mine has yielded a small amount of ore, valuable mainly for its silver and lead content.

\section{REFERENGES CITED}

Anderson, A. L., 1956, Geology and mineral resources of the Salmon quadrangle, Lemhi County, Idaho: Idaho Bureau of Mines and Geology Pamphlet 106, 102 p.

1957, Geology and mineral resources of the Baker quadrangle, Lemhi County, Idaho: Idaho Bureau of Mines and Geology Pamphlet 112, $71 \mathrm{p}$.

1959, Geology and mineral resources of the North Fork quadrangle, Lemhi County, Idaho: Idaho Bureau of Mines and Geology Pamphlet 118, $92 \mathrm{p}$.

Antweiler, J. C., and Love, J. D., 1967, Gold-bearing sedimentary rocks in northwest Wyoming-a preliminary report: U.S. Geological Survey Circular 541, 12 p.

Armstrong, R. L. 1975, Precambrian (1,500 m.y. old) rocks òf central Idaho-The Salmon River arch and its role in Cordilleran sedimentation and tectonics: American Journal of Science, v. 275A, p. $437-467$.
Axelsen, Claus, 1973, Pennsylvanian stratigraphy in south-central Idaho and adjacent areas: Corvallis, Oreg., Oregon State University M.S. thesis, 129 p.

Berg, R. B., 1977, Reconnaissance geology of southernmost Ravalli County, Montana: Montana Bureau of Mines and Geology Memoir 44, $39 \mathrm{p}$.

Berger, B. R., Vander Voort, I. L., Siems, O. F., and Welsch, E. P., 1979, Geochemical exploration studies in the Dillon, MontanaIdaho $1^{\circ} \times 2^{\circ}$ quadrangle; geochemical reconnaissance of mining districts in the southern Pioneer Mountains and vicinity, Beaverhead County, Montana: U.S. Geological Survey Open-File Report 79-1426, 45 p.

Beutner, E. C., 1968, Structure and tectonics of the southern Lemhi Range, Idaho: University Park, Pa., Pennsylvania State University $\mathrm{Ph}$. D. thesis, $106 \mathrm{p}$.

1972, Reverse gravitative movement on earlier overthrusts, Lemhi Range, Idaho: Geological Society of America Bulletin, v. 83, p. 839-846.

1977, Causes and consequences of curvature in the Sevier orogenic belt, Utah to Montana: Twenty-Ninth Annual Field Conference, 1977, Wyoming Geological Association Guidebook, p. $353-365$.

Brumbaugh, D. S., 1973, Structural analysis of the complexly deformed Big Hole River area, Madison, Beaverhead, and Silver Bow Counties, Montana: Bloomington, Ind., Indiana University Ph. D. thesis, $96 \mathrm{p}$.

Brumbaugh, D. S., and Dresser, H. W., 1976, Exposed step in Laramide thrust fault, southwest Montana: American Association of Petroleum Geologists Bulletin, v. 60, p. 2142-2166.

Brumbaugh, D. S., and Hendrix, T. E., 1974, Geometry and movement of the McCarthy Mountain structural salient, southwestern Montana: Geological Society of America Abstracts with Programs, v. 6 , no. 5 , p. 430.

Calbeck, J. M., 1975, Geology of the central Wise River valley, Pioneer Mountains, Beaverhead County, Montana: Missoula, Montana, University of Montana M.S. thesis, $89 \mathrm{p}$.

Coppinger, Walter, 1974, Stratigraphic and structural study of Belt Supergroup and associated rocks in a portion of the Beaverhead Mountains, southwest Montana, and east-central Idaho: Oxford, Ohio, Miami University Ph. D. thesis, 224 p.

Cressman E. R. 1955, Physical stratigraphy of the Phosphoria Formation in part of southwestern Montana: U.S. Geological Survey Bulletin 1027-A, p. 1-31.

Cressman, E. R., and Swanson, R. W., 1964, Stratigraphy and petrology of the Permian rocks of southwestern Montana: U.S. Geological Survey Professional Paper 313-C, p. 275-569.

Dahlstrom, C. D. A., 1977, Structural geology in the eastern margin of the Canadian Rocky Mountains: Laramie, Wyo., Wyoming Geological Association Guidebook, 29th Annual Field Conference, 1977 , p. $407-439$.

Denison, R. H., 1968, Middle Devonian fishes from the Lemhi Range of Idaho: Fieldiana Geology, v. 16, p. 269-288.

Derstler, Kraig, and McCandless, D. O., 1981, Cambrian trilobites and trace fossils from the southern Lemhi Range, Idaho-their stratigraphic and paleontologic significance: Geological Society of America Abstracts with Programs, v. 13, no. 4, p. 194.

Dover, J. H., 1975, Character and tectonic development of the Sevier orogenic belt in the northern Pioneer Mountains, central Idaho: Geological Society of America Abstracts with Programs, v. 7, no. 7 , p. 1333-1334.

-1980, Status of the Antler orogeny in central Idaho-Clarifications and constraints from the Pioneer Mountains: Society of Economic Paleontologists and Mineralogists, West-Central United States Paleogeography Symposium I, T. D. Fouch and E. R. Magathan, eds., 16 p. 
Dutro, J. T., Jr., Zen, E-an, and Taylor, M. E., 1975, Middle Cambrian in the Pioneer Mountains, southwest Montana: Geological Society of America Abstracts with Programs, v. 7, no. 7, p. 1062.

Embree, G. F., Hoggan, R. D., Williams, E. J., and Skipp, Betty, 1975, Stratigraphy of the southern Beaverhead Range, Clark and Lemhi Counties, Idaho: Geological Society of America Abstracts with Programs, v. 7, no. 5, p. 607.

Evans, K. V., and Zartman, R. E., 1981, Evidence from U-Th-Pb zircon ages for Cambrian-Ordovician plutonism in east-central Idaho: Geological Society of America Abstracts with Programs, v. 13 , no. 4 , p. 195.

Fraser, G. D., and Waldrop, H. A., 1972, Geologic map of the Wise River quadrangle, Silver Bow and Beaverhead Counties, Montana: U.S. Geological Survey Quadrangle Map GQ-988.

Garmezy, Lawrence, and Scholten, Robert, 1981, Multiple deformation in a portion of the fold and thrust belt; southern Beaverhead Mountains, east-central Idaho: Geological Society of America Abstracts with Programs, v. 13, no. 4, p. 198.

Grant, R. E., 1965, Faunas and stratigraphy of the Snowy Range Formation (Upper Cambrian) in southwestern Montana and northwestern Wyoming: Geological Society of America Memoir $96,171 \mathrm{p}$.

Geach, R. D., 1972, Mines and mineral deposits (except fuels), Beaverhead County, Montana: Montana Bureau of Mines and Geology Bulletin 85, 194 p.

Hadley, J. B., 1969a, Geologic map of the Cameron quadrangle, Madison County, Montana: U.S. Geological Survey Geologic Quadrangle Map GQ-813.

$-1969 \mathrm{~b}$, Geologic map of the Varney quadrangle, Madison County, Montana: U.S. Geological Survey Geologic Quadrangle Map GQ-814.

Hait, M. H., Jr., 1965, Structure of the Gilmore area, Lemhi Range, Idaho: University Park, Pa., Pennsylvania State University Ph. D. thesis, $134 \mathrm{p}$.

Hansen, A. M., 1952, Cambrian stratigraphy in southwestern Montana: Montana Bureau of Mines and Geology Memoir 33, $46 \mathrm{p}$.

Harrison, J. E., 1972, Precambrian Belt basin of Northwestern United States-Its geometry, sedimentation, and copper occurrences: Geological Society of America Bulletin, v. 83, p. 12151240.

Harrison, J. E., Griggs, A. B., and Wells, J. D., 1974, Tectonic features of the Precambrian Belt basin and their influence on postBelt structures: U.S. Geological Survey Professional Paper 866, $15 \mathrm{p}$.

Hays, W. H., McIntyre, D. H., and Hobbs, S. W., 1978, Geologic map of the Lone Pine Peak quadrangle, Custer County; Idaho: U.S. Geological Survey Open-File Report 78-1060.

Hobbs, S. W., 1980, The Lawson Creek Formation of middle Proterozoic age in east-central Idaho: U.S. Geological Survey Bulletin 1482-E, $12 \mathrm{p}$.

Hobbs, S. W., Hays, W. H., and MeIntyre, D. H., 1975, Geologic map of the Clayton quadrangle, Custer County, Idaho: U.S. Geological Survey Open-File Report 75-76.

Hobbs, S. W., Hays, W. H., and Ross, R. J., Jr., 1968, The Kinnikinic Quartzite of central Idaho-redefinition and subdivision: U.S. Geological Survey Bulletin 1254-J, 22 p.

Hoffman, J., Hower, J., and Aronson, J. L., 1976, Radiometric dating of time of thrusting in the disturbed belt of Montana: Geology, v. 4 , no. 1 , p. $16-20$.

Huh, O. K., 1967, The Mississippian System across the Wasatch line, east-central Idaho, extreme southwestern Montana: Billings, Mont., Billings Geological Society Guidebook, 18th Annual Field Conference, p. 31-62.

Hyndman, D. W., Talbot, J. L., and Chase, R. B., 1975, Boulder batholith: A result of emplacement of a block detached from the Idaho batholith infrastructure: Geology, v. 3, no. 7, p. 401-404.
James, H. L., and Hedge, C. E., 1980, Age of basement rocks of southwest Montana: Geological Society of America Bulletin, Part I, v. 91, p. 11-15.

James, W. C., and Oaks, R. Q., Jr., 1977, Petrology of the Kinnikinic Quartzite (Middle Ordovician), east-central Idaho: Journal of Sedimentary Petrology, v. 47, no. 4, p. 1491-1511.

Karlstrom, T. N. V., 1948, Geology and ore deposits of the Hecla mining district, Beaverhead County, Montana: Montana Bureau of Mines and Geology Memoir 25, $87 \mathrm{p}$.

Kirkham, V. R. D., 1927, A geologic reconnaissance of Clark, Jefferson, and parts of Butte, Custer, Fremont, Lemhi, and Madison Counties, Idaho: Idaho Bureau of Mines and Geology Pamphlet $19,47 \mathrm{p}$.

Klepper, M. R., 1950, A geologic reconnaissance of parts of Beaverhead and Madison Counties, Montana: U.S. Geological Survey Bulletin 969-C, p. 55-85.

Lindsey, D. A., 1972, Sedimentary petrology and paleocurrents of the Harebell Formation, Pinyon Conglomerate, and associated coarse clastic deposits, northwestern Wyoming: U.S. Geological Survey Professional Paper 734-B, 68 p.

Lopez, D. A., 1981, Stratigraphy of the Yellowjacket Formation of east-central Idaho, A reconnaissance study: Golden, Colo., Colorado School of Mines Ph. D. thesis, $252 \mathrm{p}$.

Love, J. D., 1968, Late Cretaceous and Cenozoic sedimentation and tectonism, southern Yellowstone-Jackson Hole area, Wyoming [abstract]: Geological Society of America Special Paper 121, p. 611-612.

Lowell, W. R., 1965, Geologic map of the Bannack-Grayling area, Beaverhead County, Montana: U.S. Geological Survey Miscellaneous Geologic Investigations Map I-433.

Lowell, W. R., and Klepper, M. R., 1953, Beaverhead formation, A Laramide deposit in Beaverhead County, Montana: Geological Society of America Bulletin, v. 64, p. 235-244.

Lucchitta, B. K., 1966, Structure of the Hawley Creek area, IdahoMontana: University Park, Pa., The Pennsylvania State University $\mathrm{Ph}$. D. thesis, $204 \mathrm{p}$.

M'Gonigle, J. W., 1965, Structure of the Maiden Peak area, MontanaIdaho: University Park, Pa., Pennsylvania State University Ph. D. thesis, $146 \mathrm{p}$.

Mackenzie, W. D., 1949, Geology and ore deposits of a section of the Beaverhead Range east of Salmon, Idaho: Moscow, Idaho, University of Idaho M.S. thesis, $53 \mathrm{p}$.

McMannis, W. J., 1963, Lahood Formation-A coarse facies of the Belt Series in southwestern Montana: Geological Society of America Bulletin, v. 74, p. 407-436.

-1965 , Resumé of depositional and structural history of western Montana: American Association of Petroleum Geologists Bulletin, v. 49 , p. $1801-1823$

Mamet, B. L., Skipp, Betty, Sando, W. J., and Mapel, W. J., 1971, Biostratigraphy of Upper Mississippian and associated carboniferous rocks in south-central Idaho: American Association of Petroleum Geologists Bulletin, v. 55, p. 20-33.

Mann, J. A., 1954, Geology of part of the Gravelly Range, Montana: Yellowstone-Bighorn Research Association, Inc., YellowstoneBighorn Research Project, Contribution 190, 92 p.

Mapel, W. J., Read, W. H., and Smith, R. K., 1965, Geologic map and sections of the Doublespring quadrangle, Custer and Lemhi Counties, Idaho: U.S. Geological Survey Geologic Quadrangle Map GQ-464.

Mapel, W. J., and Shropshire, K. L., 1973, Preliminary geologic map and section of the Hawley Mountain quadrangle, Custer, Butte, and Lemhi Counties, Idaho: U.S. Geological Survey Miscellaneous Field Studies Map MF-546.

Maughan, E. K., and Roberts, A. E., 1967, Big Snowy and Amsden Groups and the Mississippian-Pennsylvanian boundary in Montana: U.S. Geological Survey Professional Paper 554-B, 27 p. 
Moore, G. T., 1956, The geology of the Mount Fleecer area, Montana: Bloomington, Ind., Indiana University $\mathrm{Ph}$. D. thesis, $88 \mathrm{p}$.

Moritz, C. A., 1951, Triassic and Jurassic stratigraphy of southwestern Montana: American Association of Petroleum Geologists Bulletin, v. 35, no. 8, p. 1781-1814.

Myers, W. B., 1952, Geology and mineral deposits of the northwest quarter Willis quadrangle and adjacent Brown's Lake area, Beaverhead County, Montana: U.S. Geological Survey Trace Elements Investigations Report 259, $46 \mathrm{p}$.

Noel, J. A., 1956, The geology of the east end of the Anaconda Range and adjacent areas, Montana: Bloomington, Ind., Indiana University $\mathrm{Ph}$. D. thesis, $74 \mathrm{p}$.

Pardee, J. T., 1950, Late Cenozoic block faulting in western Montana: Geological Society of America Bulletin, v. 61, p. 359-406.

Price, R. A., 1973, Large-scale gravitational flow of supracrustal rocks, southern Canadian Rockies, in $\mathrm{K}$. A. DeJong, and Robert Scholten, eds., Gravity and tectonics [Van Bemmelen Volume]: New York, John Wiley, p. 491-502.

Prucha, J. J., Graham, J. A., and Nickelsen, R. P., 1965, Basementcontrolled deformation in Wyoming province of Rocky Mountains foreland: American Association of Petroleum Geologists Bulletin, v. 49 , p. $966-992$.

Richards, R. W., and Pardee, J. T., 1925, The Melrose phosphate field, Montana: U.S. Geological Survey Bulletin 780, p. 1-32.

Roberts, A. E., 1972, Cretaceous and early Tertiary depositional and tectonic history of the Livingston area, southwestern Montana: U.S. Geological Survey Professional Paper 526-C, 120 p.

Robinson, G. D., 1963, Geology of the Three Forks quadrangle, Montana, with sections on Petrography of igneous rocks, by $\mathrm{H}$. F. Barnett: U.S. Geological Survey Professional Paper 370, 143 p.

Robinson, G. D., Klepper, M. R., and Obradovich, J. D., 1968, Overlapping plutonism, volcanism, and tectonism in the Boulder batholith region, western Montana, in R. R. Coats, R. L. Hay, and C. A. Anderson, eds., Studies in volcanology [Howel Williams Volume]: Geological Society of America Memoir 116, p. $557-608$.

Ross, C. P., 1947, Geology of the Borah Peak quadrangle, Idaho: Geological Society of America Bulletin, v. 58, p. 1085-1160.

1961, Geology of the southern part of the Lemhi Range, Idaho: U.S. Geological Survey Bulletin 1081-F, p. 189-260.

1962a, Stratified rocks in south-central Idaho: Idaho Bureau Mines and Geology Pamphlet 125, $126 \mathrm{p}$.

1962b, Paleozoic Seas of central Idaho: Geological Society of America Bulletin, v. 73, p. 769-794.

Ruppel, E. T., 1968, Geologic map of the Leadore quadrangle, Lemhi County, Idaho: U.S. Geological Survey Geologic Quadrangle Map GQ-733.

-1972, Geology of pre-Tertiary rocks in the northern part of Yellowstone National Park, Wyoming: U.S. Geological Survey Professional Paper 729-A, 66 p.

1975, Precambrian Y sedimentary rocks in east-central Idaho: U.S. Geological Survey Professional Paper 889-A, 23 p.

1977, The thrust belt in southwest Montana and east-central Idaho: Wyoming Geological Association, 29th Annual Field Conference, Abstracts with Program, p. 14-15.

-1978, The Medicine Lodge thrust system, east-central Idaho and southwest Montana: U.S. Geological Survey Professional Paper 1031, 23 p.

-1980, Geologic map of the Patterson quadrangle, Lemhi County, Idaho: U.S. Geological Survey Geologic Quadrangle Map GQ-1529.

1982, Cenozoic block uplifts in southwest Montana and eastcentral Idaho: U.S. Geological Survey Professional Paper 1224, $24 \mathrm{p}$.
Ruppel, E. T., Watts, K. C., and Peterson, D. L., 1970, Geologic, geochemical, and geophysical investigations in the northern part of the Gilmore mining district, Lemhi County, Idaho: U.S. Geological Survey Open-file report, $56 \mathrm{p}$.

Ruppel, E. T., Ross, R. J., Jr., and Schleicher, D. L., 1975, Precambrian $\mathrm{Z}$ and Lower Ordovician rocks in east-central Idaho; U.S. Geological Survey Professional Paper 889-B, p. 25-34.

Ruppel, E. T., and Lopez, D. A., 1981, Geologic map of the Gilmore quadrangle, Lemhi County, Idaho: U.S. Geological Survey Geologic Quadrangle Map GQ-1543.

Ruppel, E. T., Wallace, C. A., Schmidt, R. G., and Lopez, D. A, 1981, Preliminary interpretation of the thrust belt in southwest Montana and east-central Idaho: Montana Geological Society, 1981 Field Conference and Symposium Guidebook, p. 139-159.

Ryder, R. T., and Ames, H. T., 1970, Palynology and age of Beaverhead Formation and their paleotectonic implications in Lima region, Montana-Idaho: American Association of Petroleum Geologists Bulletin, v. 54, p. 1155-1171.

Ryder, R. T., and Scholten, Robert, 1973, Syntectonic conglomerates in southwestern Montana-Their nature, origin, and tectonic significance: Geological Society of America Bulletin, v. 84, p. 773796.

Sahinen, V. M., 1950, Geology and ore deposits of the Highland Mountains, southwestern Montana: Montana Bureau of Mines and Geology Memoir 32, 125 p.

Sandberg, C. A., 1975, McGowan Creek Formation, New name for Lower Mississippian flysch sequence in east-central Idaho: U.S. Geological Survey Bulletin 1405-E, 11 p.

Sando, W. J., Gordon, Mackenzie, Jr., and Dutro, J. T., Jr., 1975, Stratigraphy and geologic history of the Amsden Formation (Mississippian and Pennsylvanian) of Wyoming: U.S. Geological Survey Professional Paper 848-A, 83 p.

Schmidt, C. J., Brumbaugh, D. S., and Hendrix, T. E., 1977, Fault movements and origin of the salient reentrant pattern in the disturbed belt of southwestern Montana: Geological Society of America Abstracts with Programs, v. 9, no. 6, p. 760.

Scholten, Robert, 1957, Paleozoic evolution of the geosynclinal margin north of the Snake River Plain, Idaho-Montana: Geological Society of America Bulletin, v. 68, p. 151-170.

-1967, Structural framework and oil potential of extreme southwestern Montana: Montana Geological Society Guidebook, 1967, p. 7-19.

1968, Model for evolution of Rocky Mountains east of Idaho batholith: Tectonophysies, v. 6 , no. 2, p. 10-126.

1973, Gravitational mechanisms in the Northern Rocky Mountains of the United States, in K. A. DeJong and Robert Scholten, eds., Gravity and tectonics [Van Bemmelen Volume]: New York, John Wiley, p. 473-489.

1981, Horse Prairie fault zone in southwest Montana; its role in sedimentation and tectogenesis: Geological Society of America Abstracts with Programs, v. 13, no. 4, p. 225.

Scholten, Robert, and Hait, M. H., Jr., 1962, Devonian System from shelf edge to geosyncline, southwestern Montana-central Idaho: Billings, Mont., Billings Geological Society Guidebook, 13th Annual Field Conference, p. 13-22.

Scholten, Robert, Keenmon, K. A., and Kupsch, W. O., 1955, Geology of the Lima region, southwestern Montana, and adjacent Idaho: Geological Society of America Bulletin, v. 66, p. 345-404.

Scholten, Robert, and Ramspott, L. D., 1968, Tectonic mechanisms indicated by structural framework of central Beaverhead Range, Idaho-Montana: Geological Society of America Special Paper 104, $70 \mathrm{p}$.

Shannon, J. P., Jr., 1961, Upper Paleozoic stratigraphy of east-central Idaho: Geological Society of America Bulletin, v. 72, p. 1829 1836. 
Shenon, P. J., 1931, Geology and ore deposits of Bannack and Argenta, Montana: Montana Bureau Mines and Geology Bulletin $6,79 \mathrm{p}$.

Skipp, Betty, and Hait, M. H., Jr., 1977, Allochthons along the northeast margin of the Snake River Plain, Idaho: Laramie, Wyo., Wyoming Geological Association Guidebook, 29th Annual Field Conference, 1977, p. 499-515.

Skipp, Betty, Hoggan, R. D., Schleicher, D. L., and Douglass, R. C., 1979, Upper Paleozoic carbonate bank in east-central IdahoSnaky Canyon, Bluebird Mountain, and Arco Hills Formations and their paleotectonic significance: U.S. Geological Survey Bulletin $1486,78 \mathrm{p}$.

Sloss, L. L., 1954, Lemhi arch, a mid-Paleozoic positive element in south-central Idaho: Geological Society of America Bulletin, v. 65 , p. $365-368$.

Sloss, L. L., and Moritz, C. A., 1951, Paleozoic stratigraphy of southwestern Montana: American Association of Petroleum Geologists Bulletin, v. 35, p. 2135-2169.

Snee, L. W., 1978, Petrography, K-Ar ages, and field relations of the igneous rocks of part of the Pioneer batholith, southwestern Montana: Columbus, Ohio, Ohio State University M.S. thesis, $110 \mathrm{p}$.

Smith, J. G., 1961, The geology of the Clear Creek area, MontanaIdaho: University Park, Pa., Pennsylvania State University M.S. thesis, $75 \mathrm{p}$.

Staatz, M. H., 1972, Geology and description of the thorium-bearing veins, Lemhi Pass quadrangle, Idaho and Montana: U.S. Geological Survey Bulletin 1351, 94 p.

-1973, Geologic map of the Goat Mountain quadrangle, Lemhi County, Idaho, and Beaverhead County, Montana: U.S. Geological Survey Geologic Quadrangle Map GQ-1097.

1979, Geology and mineral resources of the Lemhi Pass thorium district, Idaho and Montana: U.S. Geological Survey Professional Paper 1049-A, $90 \mathrm{p}$.

Swanson, R. W., 1970, Mineral resources in Permian rocks of southwest Montana: U.S. Geological Survey Professional Paper 313-E, p. 661-777.

Taylor, A. V., Jr., 1942, Quartz Hill district, near Divide, Montana, p. 215-216, in W. H. Newhouse, ed., Ore deposits as related to structural features: Princeton, N. J., Princeton University Press, $280 \mathrm{p}$.

Tucker, D. R., 1975, Stratigraphy and structure of Precambrian Y (Belt?) metasedimentary and associated rocks, Goldstone Mountain quadrangle, Lemhi County, Idaho, and Beaverhead County, Montana: Oxford, Ohio, Miami University Ph. D. thesis, $221 \mathrm{p}$.

Tysdal, R. G., 1970, Geology of the north end of the Ruby Range, southwestern Montana: Missoula, Mont., Montana State University $\mathrm{Ph}$. D. thesis, $187 \mathrm{p}$. 1976a, Geologic map of northern part of Ruby Range, Madison County Montana: U.S. Geological Survey Miscellaneous Investigations Map I-951.

-1976b, Paleozoic and Mesozoic stratigraphy of the northern part of the Ruby Range, southwestern Montana: U.S. Geological Survey Bulletin 1405-I, $26 \mathrm{p}$.

Umpleby, J. B., 1913, Geology and ore deposits of Lemhi County, Idaho: U.S. Geological Survey Bulletin 528, 183 p.

Wallace, C. A., Ruppel, E. T., and Klepper, M. R., 1979, Preliminary interpretation of relations among thrust systems in western Montana and east-central Idaho (abstract): Wyoming Geological Association Thrust Belt Conference, Laramie, Wyo., p. 27-28.

Wilson, M. D., 1970, Upper Cretaceous-Paleocene synorogenic conglomerates of southwestern Montana: American Association of Petroleum Geologists Bulletin, v. 54, p. 1843-1867.

Winston, D., 1973a, The Precambrian Missoula Group of Montana as a braided stream and sea-margin sequence: Moscow, Idaho, Belt Symposium, v. 1, p. 208-220.

1973b, The Bonner Formation as a late Precambrian pediplain: Northwest Geology, v. 2, p. 53-58.

1978, Fluvial systems of the Precambrian Belt Supergroup, Montana and Idaho, U.S.A.: Canadian Society of Petroleum Geologists, Memoir 5, Fluvial Sedimentology, p. 343-359.

Witkind, I. J., 1969, Geology of the Tepee Creek quadrangle, Montana-Wyoming: U.S. Geological Survey Professional Paper 609, $101 \mathrm{p}$.

1976, Geologic map of the southern part of the Upper Red Rock Lake Quadrangle, southwestern Montana and adjacent Idaho: U.S. Geological Survey Miscellaneous Investigations Map I-943.

1977, Structural pattern of the Centennial Mountains, Montana-Idaho: Laramie, Wyo., Wyoming Geological Association Guidebook, 29th Annual Field Conference, 1977, p. 531-536.

Wooden, J. L., Vitaliano, C. J., Koehler, S. W., and Ragland, P. C., 1978, The late Precambrian mafic dikes of the southern Tobacco Root Mountains-Geochemistry, Rb-Sr geochronology and relationship to Belt tectonics: Canadian Journal of Earth Sciences, v. 15 , no. 4 , p. $467-479$.

Zen, E-an, 1977a, Some regional tectonic problems inferred from the Pioneer Mountains, Montana: Geological Society of America Abstracts with Programs, Rocky Mountain Section, v. 9, no. 6, p. $779-780$.

1977b, Fault connections in southwestern Montana, in Geological Survey Research 1977: U.S. Geological Survey Professional Paper 1050, p. 66-67.

Zen, E-an, Marvin, R. F., and Mehnert, H. H., 1975, Preliminary petrographic, chemical, and age data on some intrusive and associated contact metamorphic rocks, Pioneer Mountains, Montana: Geological Society of America Bulletin, v. 86, p. 367-370. 